LA-14434-HDR

Approved for public release;

distribution is unlimited.

Subsurface Geology of the Fenton Hill

Hot Dry Rock Geothermal Energy Site 
Los Alamos National Laboratory, an affirmative action/ equal opportunity employer, is operated by Los Alamos National Security, LLC, for the National Nuclear Security Administration of the U.S. Department of Energy under contract DE-AC52-06NA25396.

\section{MUSS \\ National Nuclear Security Administration}

This report was prepared as an account of work sponsored by an agency of the U.S. Government. Neither Los Alamos National Security, LLC, the U.S. Government nor any agency thereof, nor any of their employees make any warranty, express or implied, or assume any legal liability or responsibility for the accuracy, completeness, or usefulness of any information, apparatus, product, or process disclosed, or represent that its use would not infringe privately owned rights. Reference herein to any specific commercial product, process, or service by trade name, trademark, manufacturer, or otherwise does not necessarily constitute or imply its endorsement, recommendation, or favoring by Los Alamos National Security, LLC, the U.S. Government, or any agency thereof. The views and opinions of authors expressed herein do not necessarily state or reflect those of Los Alamos National Security, LLC, the U.S. Government, or any agency thereof. Los Alamos National Laboratory strongly supports academic freedom and a researcher's right to publish; as an institution, however, the Laboratory does not endorse the viewpoint of a publication or guarantee its technical correctness. 
LA-14434-HDR

Issued: December 2010

Subsurface Geology of the Fenton Hill

Hot Dry Rock Geothermal Energy Site

Schön S. Levy

- Los Alamos 



\section{CONTENTS}

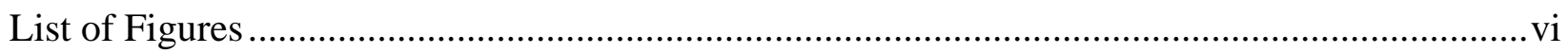

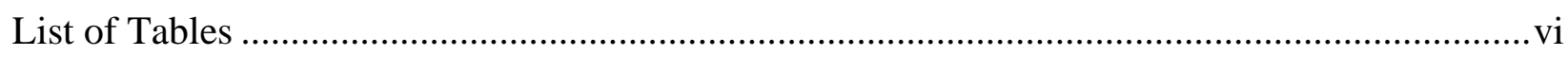

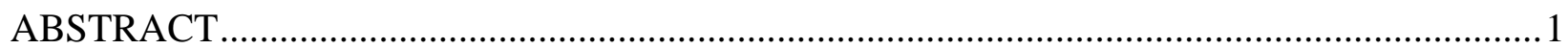

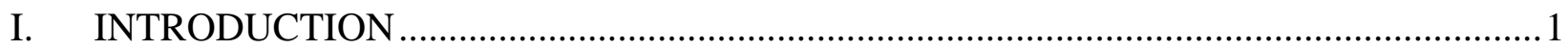

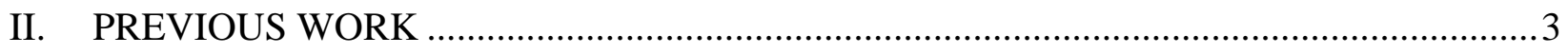

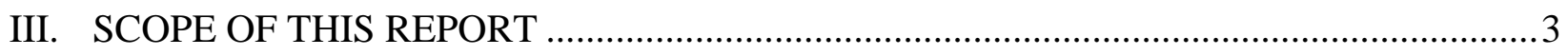

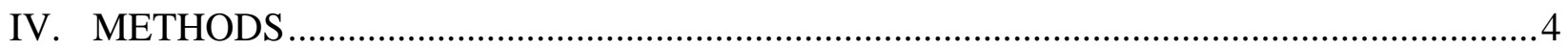

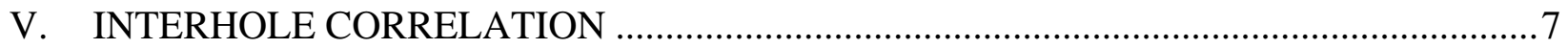

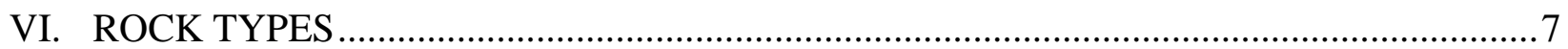

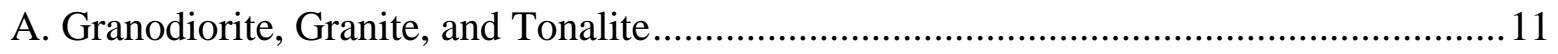

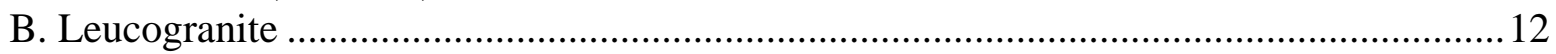

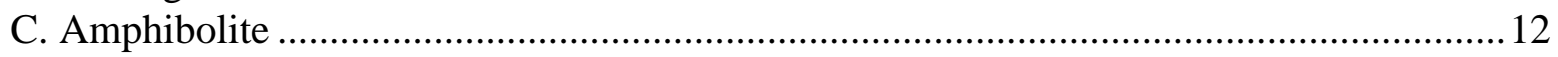

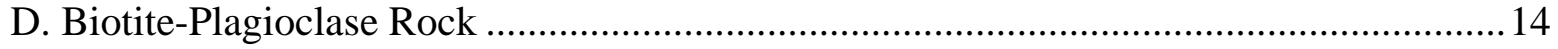

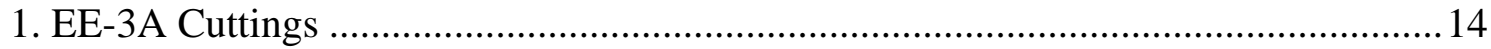

2. EE-2 Core 2 …................................................................................................. 15

3. Origin and Significance of the Biotite-Plagioclase Rock........................................ 19

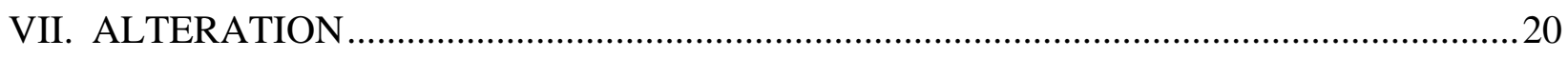

A. Reassessment of Alteration Zones in EE-2 …................................................... 21

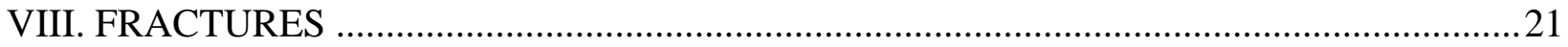

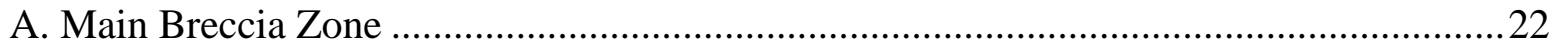

B. Fractures in Drill Cores..................................................................................... 23

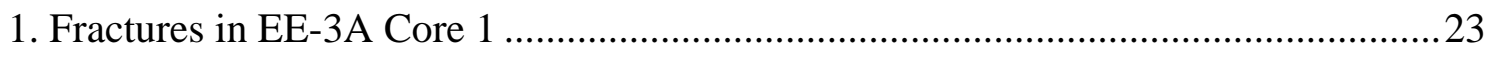

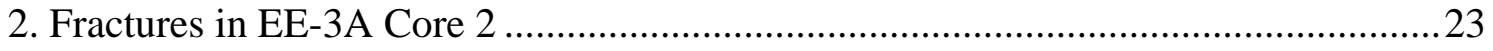

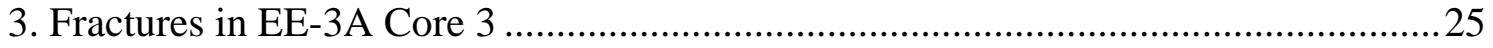

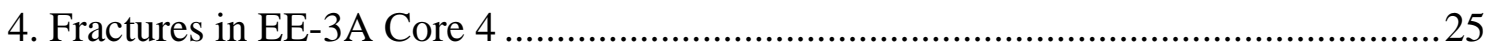

C. Characteristics of Fractures in Cuttings .................................................................. 26

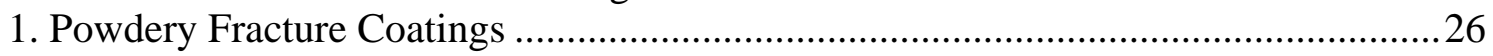

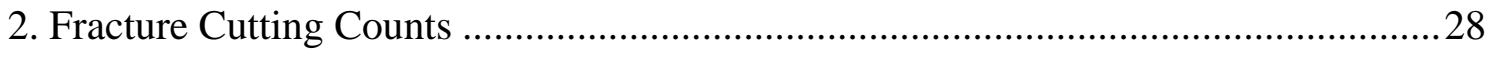

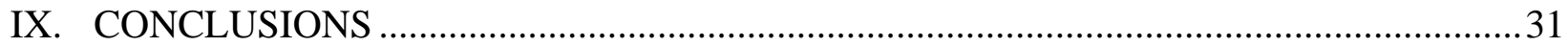

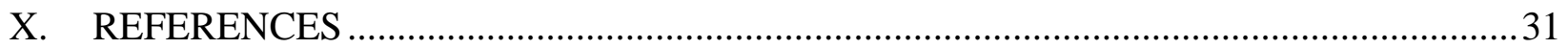

APPENDIX A: Electron Microprobe Analyses of Minerals ...............................................

APPENDIX B: Leucogranite Distribution at Fenton Hill ….............................................. B-1

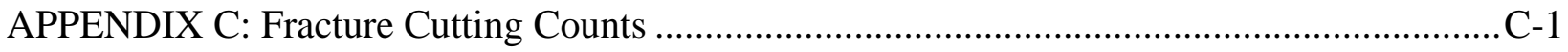




\section{LIST OF FIGURES}

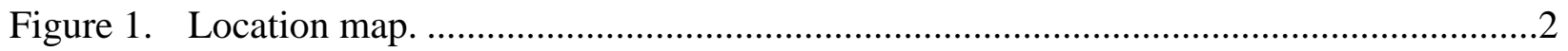

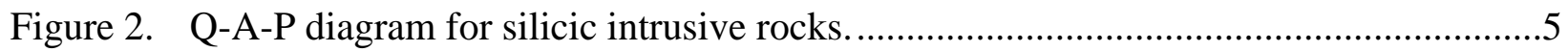

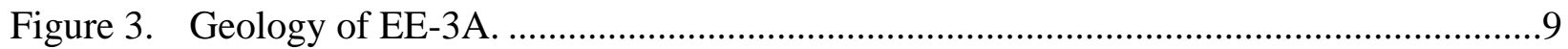

Figure 4. Conceptual representation of the geology of the Phase II reservoir.............................10

Figure 5. Euhedral sphene crystal with overgrowth, EE-2 12852-1C.......................................18

Figure 6. Rare-earth contents of sphene, EE-2 12852-1C...................................................18

Figure 7. Rare-earth contents of sphene crystals in Fenton Hill rocks........................................19

Figure 8. SEM back-scattered electron image of a fracture close to the margin of a small

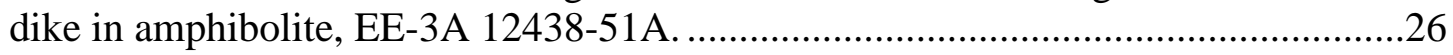

Figure 9. Fracture counts for cuttings from the upper part of EE-3A......................................29

Figure 10. Fracture counts and leucogranite dike rock abundance in cuttings from EE-2A. .......30

\section{LIST OF TABLES}

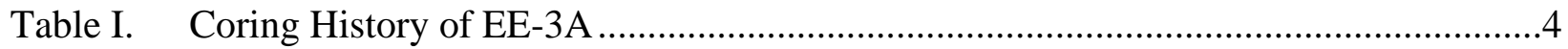

Table II. Detection Limits and Errors for Microprobe Analyses................................................6

Table III. Modal Percentages of Minerals in EE-3A Core Samples ...............................................

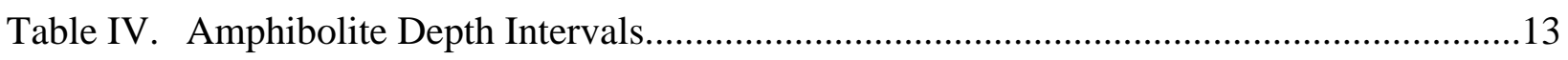

Table V. Main Breccia Zone Depth Intervals .........................................................................22 


\title{
Subsurface Geology of the Fenton Hill Hot Dry Rock Geothermal Energy Site
}

by

\author{
Schön S. Levy
}

\begin{abstract}
The Precambrian rock penetrated by wells EE-2A and -3A belongs to one or more granitic to granodioritic plutons. The plutonic rock contains two major xenolith zones of amphibolite, locally surrounded by fine-grained mafic rock of hybrid igneous origin. The granodiorite is cut by numerous leucogranite dikes that diminish in abundance with depth.

The most prominent structural feature is the main breccia zone, in which the rock is highly fractured and moderately altered. This zone is at least $75 \mathrm{~m}$ thick and is of uncertain but near-horizontal orientation. Fracture abundance decreases with increasing depth below the main breccia zone, and fractures tend to be associated with leucogranite dikes. This association suggests that at least some of the fractures making up the geothermal reservoir are of Precambrian age or have long-range orientations controlled by the presence of Precambrian-age granitic dikes.
\end{abstract}

\section{INTRODUCTION}

The Hot Dry Rock (HDR) geothermal energy project at Fenton Hill, New Mexico, on the flank of the Valles Caldera (map, Fig. 1), began in 1973. Four closely-spaced wells, including sidetracked sections, were drilled into Precambrian basement rock heated by the adjacent caldera. Subsurface hydraulic fracturing experiments created a geothermal reservoir in low-permeability plutonic and metamorphic rocks with a high geothermal gradient but no natural hydrothermal system. The drilling phase of the project was finished in 1987 with the establishment of an artificial fluid circulation system through the hydraulically fractured rock between two wells. This system is called the Phase II reservoir to distinguish it from the earlier-established and shallower Phase I system.

Geologic investigations associated with the Fenton Hill project have ranged from pure research to operational support. This report is a description of the deep Fenton Hill Precambrian geology, with emphasis on the 2,800-to 4,000-m depth interval that contains the fractured Phase II geothermal reservoir. Cuttings and cores from the wellbores have been studied to characterize geologic and structural features. The report also provides reference information for further geophysical and geochemical research that may be conducted in the wellbores or in drill core. 


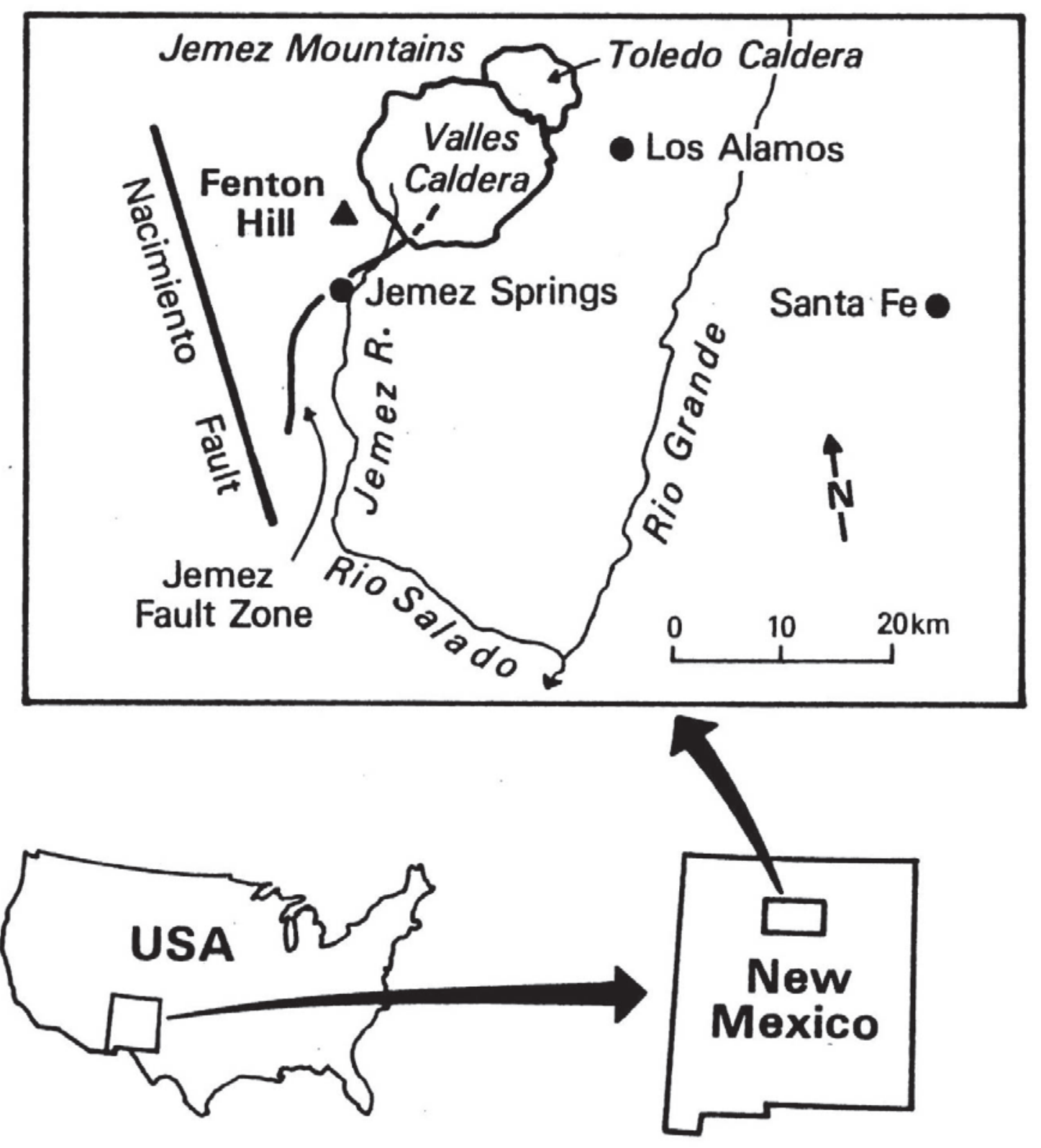

Figure 1. Location map. 


\section{PREVIOUS WORK}

The first well at Fenton Hill was GT-2, drilled in 1974 to a depth of 2928 m. In 1975, EE-1 was drilled to $3064 \mathrm{~m}$. The bottom-hole temperatures in GT-2 and EE- 1 were $197^{\circ} \mathrm{C}$ and $205^{\circ} \mathrm{C}$, respectively (Brown and others, 1979). Following several hydraulic fracturing experiments and sidetracked redrilling from GT-2, an acceptable flow connection was established between the two wells. This wellbore-fracture system is referred to as the Phase I Fenton Hill System. Plans for a deeper, hotter system required the directional drilling of EE-2 in 1979-80 to $4661 \mathrm{~m}$ and EE-3 in 1980-81 to $4084 \mathrm{~m}$. The bottom-hole temperature in EE-2 was $327^{\circ} \mathrm{C}$ (Smith and Ponder, 1982). In order to take greater advantage of the fractures between the wells, two sidetracked sections were drilled to intersect zones that were seismically active during fracturing experiments. Sidetracked well EE-3A was drilled in 1985 and EE-2A was drilled in 1987.

Basic information about the geology of pre- 1985 wells is contained in the reports for GT-2 and EE-1 (Laughlin and Eddy, 1977) and EE-2 (Laney, Laughlin, and Aldrich, 1981). There is no published report for EE-3, but a stratigraphic column of unattributed authorship was produced and distributed to HDR project members. A general description of Fenton Hill subsurface geology and the broader geologic setting also has been published (Laughlin and others, 1983). Studies of geochronology include Brookins and others (1977) and Brookins and Laughlin (1983). Relevant works on more specific aspects of Fenton Hill geology are cited in the appropriate sections of this report.

\section{SCOPE OF THIS REPORT}

This report presents new geologic data from the most recently-drilled wells EE-3A and EE-2A. The two wells penetrated approximately the 9,000- to $12,000-\mathrm{ft}(2,743-3,658 \mathrm{~m})$ vertical depth interval containing the Phase II geothermal reservoir. As information has accumulated from the new boreholes, it has been necessary to re-examine and, in some cases, to reinterpret sample material from the older wells. Selected samples from the older wells were examined to address operational concerns and to check interpretations, but a complete re-examination of all archival material was not practical.

Subsurface mapping of plutonic and metamorphic rocks was a special challenge to HDR geologists. These rock types have traditionally been studied almost exclusively in outcrops and mine workings. The rocks penetrated by wellbores at Fenton Hill contain features pertinent to Precambrian history, plutonic processes, and tectonism. Because the material available for study is predominantly drill cuttings, plus a small amount of core, there is little direct information available about features larger than millimeter scale. Mafic xenolith zones, multiple dike intrusions, and fracture zones are among the features of interest that have been identified but could not be fully characterized. This report includes an analysis of fractures in cuttings and cores because fractures are central to the success of the geothermal project.

From the early days of the project, researchers recognized that the Precambrian section includes both igneous and metamorphic rocks. The igneous or metamorphic origins of many crystalline rocks are readily apparent from characteristic textures and mineral assemblages. Some rocks, such as granites and metamorphic gneisses of similar bulk composition, cannot always be easily distinguished from each other. In order to make the most complete geologic interpretations possible, I have attempted to address and resolve questions of igneous versus metamorphic origin for the Fenton Hill samples. The discriminant criteria are identified and discussed in each case. 


\section{METHODS}

The materials available for geologic study are bit cuttings and a small amount of drill core. Drill core represents less than $1 \%$ of the total footage drilled [about $56,959 \mathrm{ft}(17,361.1 \mathrm{~m})$ drilled in GT-2, EE-1, EE-2, EE-3, EE-2A, and EE-3A], but was of critical importance in defining the relationships among lithologic units and the textural variations within these units. Table I summarizes the coring history of EE-3A. No core was taken from EE-2A. All logging and sampling operations for this project used the English system of measurement, and sample depths reported in this paper are given in both feet and equivalent metric units. Because the borehole trajectories deviate substantially from vertical, the drilling depths used for sample identification are significantly different from true vertical depths. Selected depth information has been converted from drilling depth to true vertical depth (TVD). Sample identification numbers for both core and cutting samples include the drill hole designation and the sample depth or depth range in feet.

Table I. Coring History of EE-3A

\begin{tabular}{|c|l|c|l|}
\hline Run & \multicolumn{1}{|c|}{ Drilling Depth in ft/m } & Recovery & \multicolumn{1}{|c|}{ Geologic Description } \\
\hline 1 & $9450-9455 / 2880.5-2881.9$ & $100 \%$ & Amphibolite with leucogranite dikes \\
\hline 2 & $10875-10880 / 3314.7-3316.2$ & $55 \%$ & Leucogranite, highly fractured \\
\hline 3 & $11600-11615 / 3535.7-3540.3$ & $70 \%$ & Granodiorite and leucogranite dikes \\
\hline 4 & $12439-12469 / 3791.1-3800.5$ & $77 \%$ & Amphibolite with tonalite dikes \\
\hline
\end{tabular}

Bit cutting samples were routinely collected every ten feet $(3.05 \mathrm{~m})$ of drilling depth. Samples were washed with water to remove drilling mud and rock flour. EE-2A and -3A yielded the largest cuttings and least contaminated cutting samples because the circulating fluid was drilling mud rather than water. The older wells were drilled with water, and the cuttings from the deeper parts of these wells are very fine-grained and contaminated with material from shallower depths. The archival set of cutting samples from EE-2 is incomplete, making this the well with the least-known geology.

Cutting samples from 9,400 to 13,180 ft. $(2,865$ to 4,017 m) drilling depth in EE-3A and from $9,742$ to $12,350 \mathrm{ft}$. (2,969 to $3,764 \mathrm{~m})$ in EE-2A were examined under a binocular microscope at magnifications of 6.5 to $40 x$. Samples subjected to complete examination contained a minimum of about 3,000 to 5,000 individual cuttings. Each sample was studied to identify the proportions of different rock types it contained. Identification of multiple rock types was based on differences in mineralogy, mineral proportions, and texture. Special attention was given to cuttings containing fractures or evidence of alteration. For selected samples, the number of fractures and types of fracture coatings were recorded, as were the amounts and types of altered material.

Core from EE-3A was examined under a binocular microscope for such features as lithologic contacts, fractures, shear zones, and altered areas. Unless otherwise indicated, thicknesses of small lithologic units in cores were measured perpendicular to contacts. Portions of core, as well as certain cutting samples and separates, were selected for thin section preparation. Petrographic studies included mineral identification, textural description, and modal analysis (determination of volumetric proportions of minerals). Grain-size terminology is based on Williams, Turner, and Gilbert (1954), in which rocks with grain diameters less than $1 \mathrm{~mm}$, between 1 and $5 \mathrm{~mm}$, and between $5 \mathrm{~mm}$ and $3 \mathrm{~cm}$ are, respectively, termed fine-grained, medium-grained, and coarse-grained. Granitic rock names, as defined by the International Union of Geological Sciences (IUGS; Streckeisen, 1973), are based on volumetric proportions of quartz, alkali feldspar, and plagioclase (Fig. 2). An additional term, "leucogranite," denotes monzogranites with less than about $5 \%$ mafic minerals. 
Electron microprobe analysis was performed on a small number of samples to provide information about mineral compositions (Appendix A). Analyses were done on an automated Cameca microprobe equipped with both wavelength- and energy-dispersive detectors. All analyses were obtained at a $15 \mathrm{nA}$ sample current. Typical detection limits and standard errors due to counting statistics for the common minerals are shown in Table II. Energy-dispersive x-ray spectra were collected to check the elemental contents of minerals. Feldspar compositional data in the text of this report are expressed as proportions, normalized to $100 \%$, of the end members albite (Ab, $\mathrm{NaAlSi}_{3} \mathrm{O}_{8}$ ), anorthite $\left(\mathrm{An}, \mathrm{CaAl}_{2} \mathrm{Si}_{2} \mathrm{O}_{8}\right)$, orthoclase $\left(\mathrm{Or}, \mathrm{KAlSi}_{3} \mathrm{O}_{8}\right)$, and celsian $(\mathrm{Cn}$, $\mathrm{BaAl}_{2} \mathrm{Si}_{2} \mathrm{O}_{8}$ ). The compositions of calcium-bearing plagioclase grains are shown simply in percent of the An molecule. Iron values are expressed as ferrous iron oxide $(\mathrm{FeO})$ for all minerals except sphene, in which the iron oxide is assumed to be $\mathrm{Fe}_{2} \mathrm{O}_{3}$.

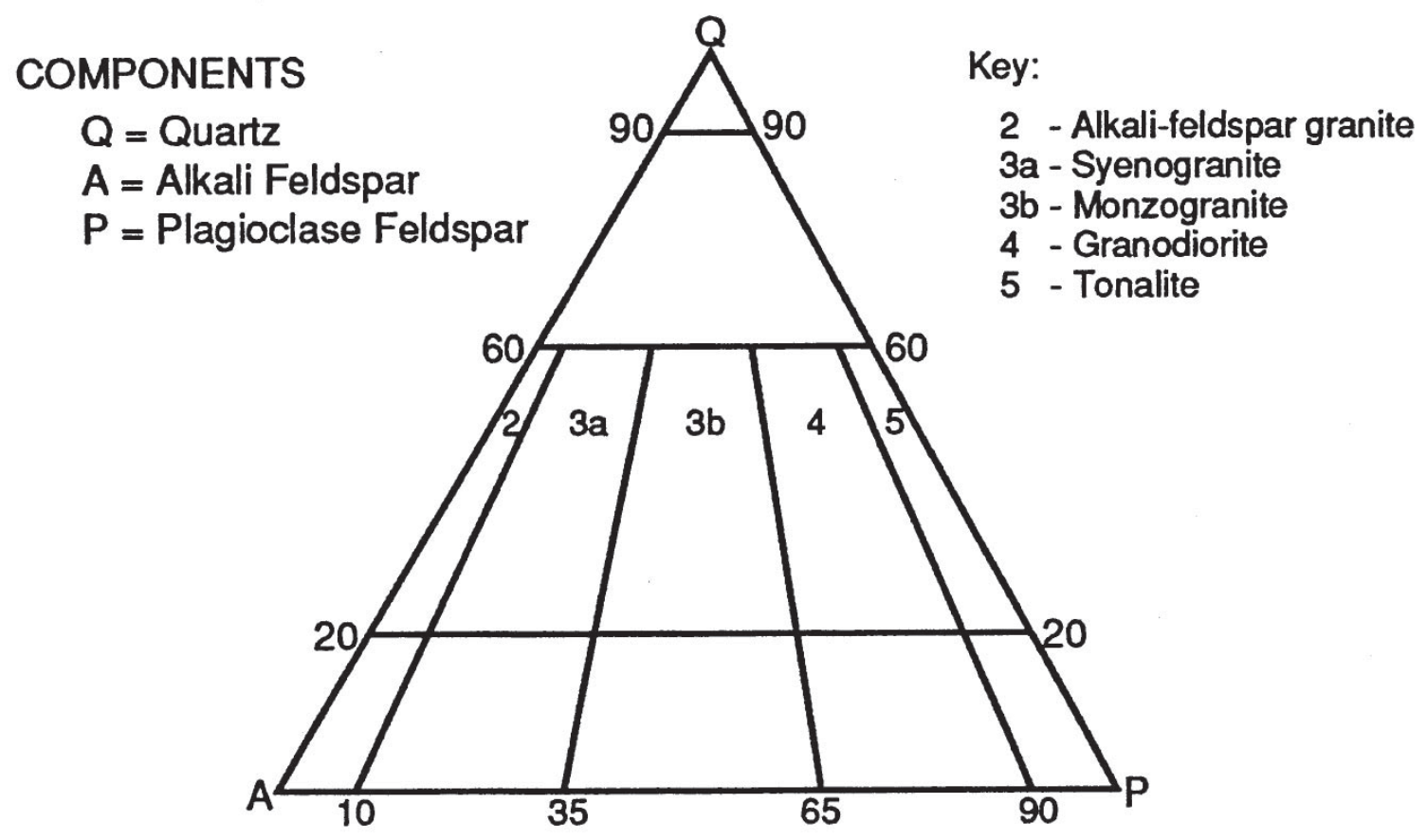

Figure 2. Q-A-P diagram for silicic intrusive rocks [from International Union of Geological Sciences (IUGS) classification]. 
Table II. Detection Limits and Errors for Microprobe Analyses

\begin{tabular}{|l|l|l|l|l|l|l|l|l|l|l|l|l|}
\hline & \multicolumn{2}{|c|}{ Feldspar } & \multicolumn{2}{c|}{ Biotite } & \multicolumn{2}{c|}{ Amphibole } & \multicolumn{2}{c|}{ Clinopyroxene } & \multicolumn{2}{c|}{ Garnet } & \multicolumn{2}{c|}{ Sphene } \\
\cline { 2 - 14 } & D.L. $^{1}$ & Error & D.L. & Error & D.L. & Error & D.L. & Error & D.L. & Error & D.L. & Error \\
\hline $\mathrm{SiO}_{2}$ & 0.02 & \pm 0.4 & 0.05 & \pm 0.3 & 0.03 & \pm 0.3 & 0.02 & \pm 0.3 & 0.04 & \pm 0.3 & 0.02 & \pm 0.2 \\
\hline $\mathrm{TiO}_{2}$ & 0.02 & \pm 0.1 & 0.1 & \pm 0.1 & 0.03 & \pm 0.1 & 0.02 & \pm 0.1 & 0.03 & \pm 0.03 & 0.02 & \pm 0.5 \\
\hline $\mathrm{Al}_{2} \mathrm{O}_{3}$ & 0.03 & \pm 0.1 & 0.05 & \pm 0.1 & 0.04 & \pm 0.1 & 0.03 & \pm 0.03 & 0.04 & \pm 0.2 & 0.04 & \pm 0.05 \\
\hline $\mathrm{Cr}_{2} \mathrm{O}_{3}$ & $-{ }^{3}$ & - & - & - & 0.04 & \pm 0.05 & 0.03 & - & 0.03 & - & - & - \\
\hline $\mathrm{FeO}$ & 0.04 & \pm 0.04 & 0.07 & \pm 0.3 & 0.02 & \pm 0.3 & 0.04 & \pm 0.1 & 0.04 & \pm 0.3 & - & - \\
\hline $\mathrm{Fe}_{2} \mathrm{O}_{3}$ & - & - & - & - & - & - & - & - & - & - & 0.05 & \pm 0.07 \\
\hline $\mathrm{MnO}$ & - & - & 0.09 & \pm 0.05 & 0.02 & \pm 0.05 & 0.04 & \pm 0.05 & 0.04 & \pm 0.4 & 0.02 & \pm 0.05 \\
\hline $\mathrm{MgO}$ & 0.04 & \pm 0.02 & 0.05 & \pm 0.1 & 0.02 & \pm 0.1 & 0.04 & \pm 0.1 & 0.05 & \pm 0.04 & 0.03 & \pm 0.01 \\
\hline $\mathrm{BaO}$ & 0.04 & \pm 0.1 & - & - & 0.02 & \pm 0.05 & - & - & - & - & - & - \\
\hline $\mathrm{CaO}$ & 0.04 & \pm 0.1 & 0.03 & - & 0.01 & \pm 0.1 & 0.04 & \pm 0.2 & 0.04 & \pm 0.03 & 0.02 & \pm 0.2 \\
\hline $\mathrm{Na}_{2} \mathrm{O}$ & 0.05 & \pm 0.2 & 0.06 & - & 0.02 & \pm 0.03 & 0.05 & \pm 0.03 & - & - & - & - \\
\hline $\mathrm{K}_{2} \mathrm{O}$ & 0.04 & \pm 0.1 & 0.03 & \pm 0.1 & 0.02 & \pm 0.02 & - & - & - & - & - & - \\
\hline $\mathrm{F}$ & - & - & 1.7 & - & 0.8 & \pm 0.5 & - & - & - & - & 1.5 & - \\
\hline $\mathrm{Ce}_{2} \mathrm{O}_{3}$ & - & - & - & - & - & - & - & - & - & - & 0.03 & \pm 0.1 \\
\hline $\mathrm{La}_{2} \mathrm{O}_{3}$ & - & - & - & - & - & - & - & - & - & - & 0.08 & \pm 0.04 \\
\hline $\mathrm{Y}_{2} \mathrm{O}_{3}$ & - & - & - & - & - & - & - & - & - & - & 0.07 & \pm 0.05 \\
\hline $\mathrm{ZrO}_{2}$ & - & - & - & - & - & - & - & - & - & - & 0.12 & - \\
\hline
\end{tabular}

${ }^{1} \mathrm{D}$. L. is the detection limit in wt \%.

${ }^{2}$ Error is the one-sigma error, in wt \%, based on counting statistics.

${ }^{3} \mathrm{~A}$ "-" in both columns indicates that the element in question was not analyzed for the given mineral. A "-" only in the error column indicates that analyzed quantities were below the detection limit. 
Sphene compositional data were collected to help trace the origins of certain rock units. The significant variations in sphene composition are in the contents of rare-earth elements (REE). Of those REE likely to be found in sphene, only cerium was determined quantitatively for all crystals analyzed. Yttrium and lanthanum were determined for selected samples. The amount by which a sphene analysis total falls below $100 \mathrm{wt} \%$ is taken as an approximation of the unanalyzed REE content expressed as wt \% $\mathrm{RE}_{2} \mathrm{O}_{3}$.

Fractures in thin sections from EE-3A core 4 and selected fractures in cuttings were examined with an International Scientific Instruments model DS-130 scanning electron microscope (SEM), equipped with an energy-dispersive $\mathrm{x}$-ray detector, operated at 19kV. Back-scattered electron images at magnifications up to $1.1 \mathrm{kx}$ were observed and photographed. The SEM also was used to check published mineral identifications for selected thin sections from older Fenton Hill wells.

Selected core, cuttings, and thin sections from wells drilled before EE-3A and -2A were re-examined and reinterpreted on the basis of information obtained from study of new material. Some of the reinterpretations are at variance with previously published descriptions and interpretations; the differences and reasons for reinterpretation are described in the appropriate sections of this report.

\section{INTERHOLE CORRELATION}

The correlation of geologic features among drill holes in granitic rocks can be extremely difficult because the rocks do not contain anything comparable to marker horizons or stratified layers in sedimentary rocks. Boundaries between plutonic units may be highly nonplanar. Distinctive features, such as dikes or xenolith zones, may not have sufficient lateral extent to be intersected by multiple drill holes or may show large variations in thickness between drill holes. In addition, dikes of similar lithology may be so numerous that dike rock from a given depth in one drill hole cannot be uniquely correlated to a single dike in another hole. West and Laughlin (1976) reported the successful use of spectral gamma logs to correlate dikes between GT-2 and EE-1, a fortuitous case in which a small number of near-horizontal dikes could be identified in both wells with a high degree of certainty.

In the course of this study, a few criteria were established to aid interhole correlation. The most reliable criterion for correlating geologic features is the degree of distinctiveness. Features may have distinctive lithology, mineralogy, texture, structure, alteration, or setting. The interhole continuity of a feature that is unique within each drill hole and is found in more than one hole (preferably all holes) can be reliably inferred if such continuity makes good geologic sense. Features that are not unique may still be correlated, although with less certainty, if they are sufficiently isolated. For example, if two xenolith-bearing intervals, with a vertical separation of more than $300 \mathrm{~m}$, are encountered in at least three drill holes, it is reasonable to infer the existence of two or more separate xenolith zones - an upper and a lower zone. For these correlations, there is an inherent assumption that the features being correlated have the simplest possible geometry.

\section{ROCK TYPES}

The rocks encountered below about 2,800 m vertical depth can be simply divided into felsic and mafic rock types. The felsic rocks are all granitic and are by far the more abundant of the two types. Mafic rocks are predominantly amphibolites. Rock types are described below in order of decreasing abundance. Modal analyses of EE-3A core samples are given in Table III. The vertical distribution of rock types described in the following sections is shown for EE-3A (Fig. 3). A conceptual representation of the major geologic units and features, based on data from EE-1, EE-2, EE-3, EE-2A, and EE-3A, is portrayed in Fig. 4. 


\begin{tabular}{|c|c|c|c|c|c|}
\hline \multicolumn{6}{|c|}{ Table III. Modal Percentages of Minerals in EE-3A Core Samples } \\
\hline & $10877.8 b$ & $11600-2$ & $11615-8 A$ & $11615 F$ & 12438-51C \\
\hline Quartz & 31.4 & 28.7 & 32.7 & 31.8 & - \\
\hline Plagioclase & 34.0 & 39.8 & 36.9 & 35.0 & 20.6 \\
\hline Microcline & 27.4 & 16.8 & 22.4 & 28.2 & - \\
\hline Biotite & - & 9.2 & 5.1 & - & 5.0 \\
\hline Hornblende & - & - & - & - & 59.0 \\
\hline Sphene & - & 0.3 & 0.2 & 0.1 & trace \\
\hline Opaques & - & 0.6 & 0.6 & trace & 1.4 \\
\hline Apatite & trace & 0.3 & trace & trace & trace \\
\hline Tourmaline & trace & - & - & - & - \\
\hline Epidote & 0.8 & 2.4 & 1.2 & 2.2 & - \\
\hline Chlorite & 0.2 & 0.3 & 0.2 & 0.3 & 0.5 \\
\hline Muscovite & 1.4 & - & - & 1.4 & 0.8 \\
\hline Sericite & - & 1.5 & 0.6 & 0.6 & 12.0 \\
\hline Calcite & 2.4 & - & - & 0.3 & 0.2 \\
\hline Hematite & 2.4 & - & - & 0.1 & - \\
\hline Prehnite & - & - & - & - & 0.6 \\
\hline Actinolite & - & - & - & - & trace \\
\hline \multicolumn{6}{|c|}{ IUGS coordinates } \\
\hline Q & 34 & 34 & 36 & 33 & - \\
\hline $\mathrm{P}$ & 56 & 70 & 63 & 55 & - \\
\hline A & 44 & 30 & 37 & 45 & - \\
\hline \multicolumn{6}{|c|}{ Rock Name } \\
\hline & $\mathrm{LG}^{*}$ & GD & MG & LG & AMP \\
\hline Points counted & 503 & 327 & 504 & 1289 & 642 \\
\hline
\end{tabular}




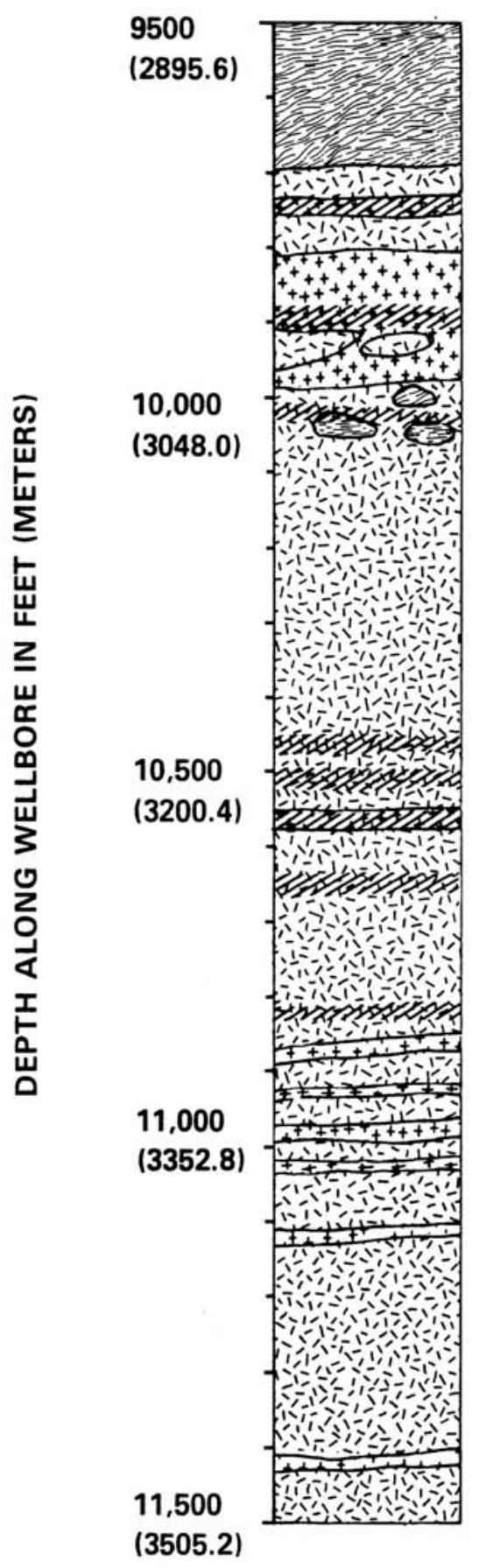

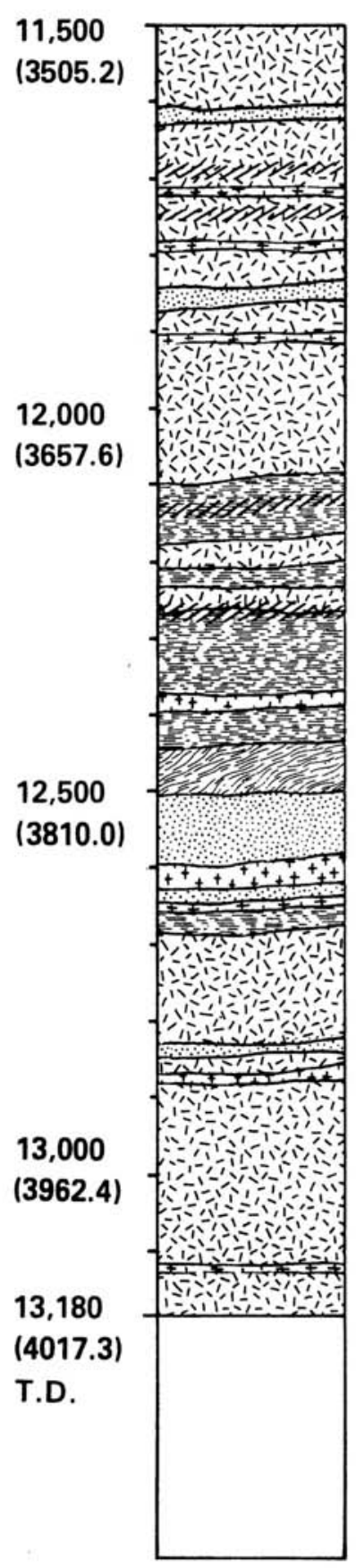

\section{LITHOLOGY}

塎究 Biotite granodiorite

Biotite granite

Light granite dikes

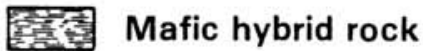

Amphibolite schist

EII]

Fracture-microbreccia zone

Figure 3. Geology of EE-3A. 


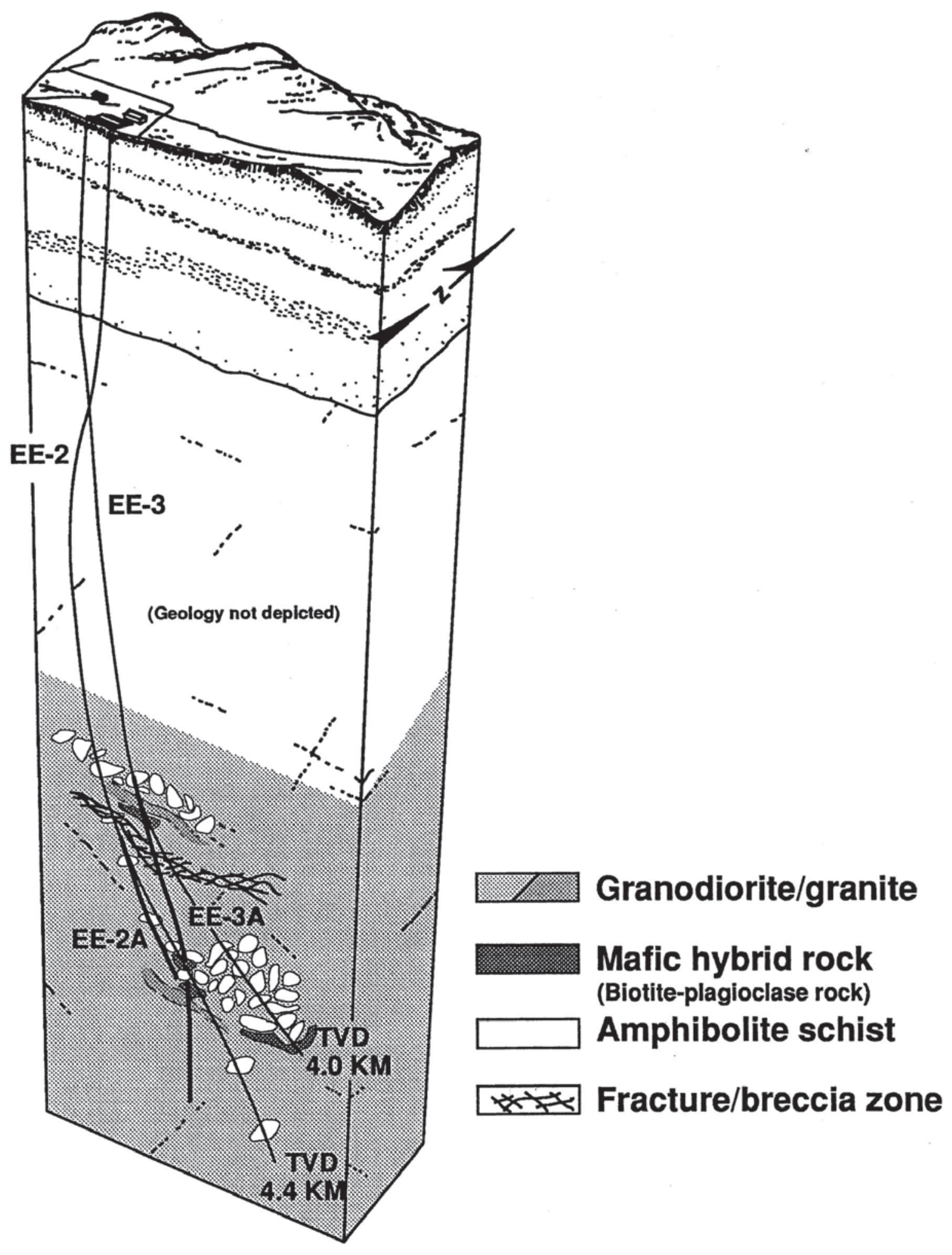

Figure 4. Conceptual representation of the geology of the Phase II reservoir. 


\section{A. Granodiorite, Granite, and Tonalite}

Petrographic data from cuttings indicate that most of the rocks penetrated by drill holes EE-3A and $-2 \mathrm{~A}$ are granodiorites and related rocks. The cores taken in EE-3A coincidentally contain very little granodiorite. Core 3 contains two intervals of medium-grained biotite granodiorite (thicknesses $\geq 61 \mathrm{~cm}$ and $\geq 10 \mathrm{~cm}$ ) and $\mathrm{a} \geq 82.6-\mathrm{cm}$ interval of fine-grained biotite monzogranite. The relationships among these intervals are obscured by leucogranite dikes. Amphibolite in core 4 is cut by two dikes $(5 \mathrm{~cm} ; \geq 30 \mathrm{~cm})$ of medium- to coarse-grained tonalite.

The granodiorite in core 3 and the larger tonalite dike in core 4 both have distinct fabrics defined by parallel alignment of elongate mafic mineral segregations, mostly biotite. Similar fabrics are also present in the granodiorites of EE-2 cores $1[11,738 \mathrm{ft}(3577.6 \mathrm{~m})$ to $11,744 \mathrm{ft}(3579.5 \mathrm{~m})]$ and 6 $[14,962 \mathrm{ft}(4560.4 \mathrm{~m})$ to $14,966 \mathrm{ft}(4561.6 \mathrm{~m})]$. Foliations cannot be positively identified in most cutting samples, but the evidence from cores and junk basket samples suggests that the granodiorites and tonalites are commonly foliated. Foliation in the tonalite dike in EE-3A core 4 is of mixed origin, being partly inherited from assimilated and recrystallized metamorphic xenoliths and partly formed by magma flow. Immediately adjacent to the exposed wall of the larger dike in this core, the tonalite fabric is aligned parallel to the dike wall and concordant to the foliation of the host amphibolite. The tonalite foliation near the dike wall is partly defined by thin stringers of biotite, epidote, sphene, and Fe oxides. The stringers are slivers of recrystallized amphibolite incorporated into the dike. Amphibolite recrystallization along dike margins is described in detail below. The tonalite fabric deviates from this parallel alignment away from the dike wall, a characteristic of primary igneous flow foliation. Granodiorite and tonalite foliations elsewhere in the Precambrian section may be of similar mixed origin.

The granodiorite in EE-3A core 3 (11600-2) is medium-to coarse-grained and hypidiomorphic-granular. Variably-sericitized plagioclase crystals $\left(\mathrm{An}_{28-30}\right)$ are the most abundant phase. Plagioclase crystals adjacent to microcline commonly have irregular overgrowths of myrmekite (intergrown plagioclase and vermicular quartz). Quartz crystals, up to $1 \mathrm{~cm}$ across, are irregularly shaped and have undulose extinction. Microcline contains rare perthite lamellae and is locally surrounded or replaced by grains of myrmekite.

As described above, the mafic minerals are in scattered elongate aggregates. The principal mafic mineral is biotite, commonly with a texture of vermicular intergrowths with quartz or feldspar. The biotite is variably altered to chlorite. Associated mafic minerals, in order of decreasing abundance, are epidote (including allanite), Fe oxides, sphene (mostly anhedral), apatite, and zircon. In at least some cases, the minerals in the mafic aggregates formed by recrystallization of hornblende, which is preserved as small remnant blebs in quartz, feldspar, and apatite adjacent to the aggregates and particularly within the vermicular intergrowths.

The fine-grained biotite monzogranite in EE-3A core 3 (11615-8A) is hypidiomorphic-granular, with local granophyric intergrowths of quartz and microcline. Plagioclase crystals are mostly subhedral and show strong discontinuous compositional zoning ( $\mathrm{An}_{30}$ cores, $\mathrm{An}_{19}$ rims $)$. Biotite has been locally replaced by epidote and chlorite. Fe oxides and mostly euhedral sphene are common accessories, with smaller amounts of apatite and zircon.

The two tonalite dikes in core 4 both contain plagioclase, quartz, and biotite, with accessory sphene (mostly anhedral), apatite, zircon, magnetite, and epidote. Sample EE-3A 12438-9 contains more biotite, plus allanite and distinctive large zircon crystals. The dike represented by sample 12438-14 contains less biotite (except in amphibolite inclusions) and has a very small amount of microcline. Hornblende in the amphibolite slivers within this tonalite dike and in amphibolite adjacent to the dike has recrystallized almost completely to biotite, sphene, epidote, magnetite, apatite, and zircon. A few small blebs of residual hornblende remain in the recrystallized inclusions. The hornblende blebs have slightly higher Fe:Mg and possibly lower Ti content than hornblende in the intact 
amphibolite. Textural relations between the amphibolite, recrystallized amphibolite inclusions, and dike rock suggest that the potassium required for the recrystallization of hornblende to biotite probably came from the dike magma. The tonalitic composition of the microcline-poor dike rock might therefore result from assimilation of amphibolite into magma with a composition closer to granodiorite.

\section{B. Leucogranite}

Leucogranite dikes are common through most of the sections penetrated by EE-2A and -3A. This rock type is distinguished by a near absence of mafic minerals. Dike rock is most abundant in the upper part of the section penetrated by the sidetracked holes, above 11,126 $\mathrm{ft}(3,391 \mathrm{~m}) \mathrm{TVD}$ in EE-2A and 11,416 ft (3,480 m) TVD in EE-3A (Appendix B). The largest concentration of leucogranite dike rock is the 9,630-to-9,950 ft/2,938-to-3,033 m (9,460-to-9,754 ft/2,883- to-2,973 m TVD) interval in EE-3A. In EE-2A, the $11,250-11,340 \mathrm{ft} / 3,429-3,456 \mathrm{~m}$ (11,045-11,126 ft/3,367-3,391 m TVD) interval contains a high abundance of leucogranite. The maximum thickness of individual dikes may be about $15 \mathrm{~m}$.

Leucogranite is present in EE-3A cores 1, 2, and 3. Core 2 is entirely leucogranite $(83.8 \mathrm{~cm}$ long) with no included lithologic boundaries. Core 3 contains a leucogranite dike about $5 \mathrm{~cm}$ wide in granodiorite and $\mathrm{a} \geq 1.2 \mathrm{-m}$ section of leucogranite with no lithologic boundaries. The dike rocks in core and cuttings vary in color from white to pink. Hematite fracture fillings give much of the leucogranite a mottled red-and-white color. The abundant fractures in EE-3A core 2 are described in Section VIII.

The leucogranites are medium- to coarse-grained, with plagioclase, quartz, and microcline as the dominant minerals. The most calcic primary plagioclase compositions preserved in EE-3A core 2 are $\mathrm{An}_{10-12}$, and microcline compositions are in the range $\mathrm{Or}_{97-94} \mathrm{Ab}_{3-6}$. Evidence of subsolvus unmixing in the alkali feldspar includes perthite lamellae $\left(\mathrm{An}_{\mathrm{l}-2}\right.$ in EE-3A core 2$)$ and overgrowths of albite $\left(\mathrm{An}_{2-5}\right.$ in EE-3A core 2$)$ on plagioclase crystals adjacent to microcline. Muscovite is usually present as an alteration product of plagioclase and, possibly, of biotite. The content of mafic minerals is less than about $3 \%$. In most leucogranites, Fe oxide may be the only remnant of a primary mafic phase. Epidote and chlorite of deuteric origin are the most abundant mafic minerals. Spessartine garnet and tourmaline are local varietal minerals. Accessory minerals include apatite, allanite, and very minor tourmaline.

\section{Amphibolite}

Hornblende-rich amphibolites were recovered in EE-3A cores 1 and 4. Table IV summarizes the locations of amphibolites in EE-2A, EE-3, and EE-3A, based on cutting studies. Amphibolite was recovered in the 11,100 and 11,308 -ft junk basket runs and in the two deepest cores [14,501-14,504 ft (4,419.9-4,420.8 m); 14,962-14,966 ft (4560.4-4561.6 m)] from EE-2. These data define two main amphibolite intervals within the depths penetrated by the sidetracked holes: an upper interval about $200 \mathrm{ft}(61 \mathrm{~m})$ thick and a lower interval that is very thin [about $50 \mathrm{ft}(15 \mathrm{~m})$ ] in EE-3A and either unrecognized or not intercepted in EE-2A, but about $1200 \mathrm{ft}(366 \mathrm{~m})$ thick in EE-3. Neither interval is composed exclusively of amphibolite. The relationship of the deep EE-2 amphibolite cores to the lower interval is uncertain; they could represent a deep extension of the amphibolite interval or one or more separate masses. 
Table IV. Amphibolite Depth Intervals

\begin{tabular}{|l|l|l|}
\hline \multicolumn{1}{|c|}{ Drill Hole } & \multicolumn{1}{|c|}{ Drilling Depth (ft/m) } & \multicolumn{1}{c|}{ True Vertical Depth (ft/m) } \\
\hline \multirow{2}{*}{ EE-2A } & $9,810-9,830 / 2,990.1-2,996.2$ & $9,704-9,723 / 2,957.8-2,963.6$ \\
\cline { 2 - 3 } & $10,380-10,400 / 3,163.8-3,169.9$ & $10,251-10,270 / 3,124.5-3,130.3$ \\
\cline { 2 - 3 } & $11,100-11,135 / 3,383.3-3,394.0$ & $10,910-10 ; 941 / 3,325.4-3.334 .8$ \\
\hline \multirow{2}{*}{ EE-3 } & $9,430-9,795 / 2,874-2,986$ & $9,294-9,626 / 2,833-2,934$ \\
\cline { 2 - 3 } & $12,040-13,300 / 3,670-4,054$ & $11,510-12,531 / 3,508-3,819$ \\
\hline \multirow{2}{*}{ EE-3A } & $9,450-9,695 / 2,880.4-2,955.0$ & $9,280-9,510 / 2,828.5-2,898$. \\
\cline { 2 - 3 } & $12,100-12,180 / 3,668.1-3,712.5$ & $11,861-11,941 / 3,615.2-3,640.0$ \\
\cline { 2 - 3 } & $12,438-12,480 / 3,791.1-3,803.9$ & $12,195-12,236 / 3,717.0-3,729.5$ \\
\hline
\end{tabular}

The amphibolite in EE-3A core 1 is medium-grained and has a schistose fabric defined by alignment of elongate hornblende and biotite crystals. Several thin $(<1 \mathrm{~cm})$ dikes of white plagioclase-quartz-microcline leucogranite cut the amphibolite. Hornblende, plagioclase, quartz, and biotite are the main amphibolite constituents. Accessory minerals include epidote, anhedral sphene, opaques with partial mantles of sphene, and apatite. Adjacent to the indistinct margins of the leucogranite dikes, hornblende has been partly replaced by aggregates of biotite, epidote, opaques, euhedral pink-brown sphene crystals up to $2 \mathrm{~mm}$ long, apatite, quartz, and calcite. Large poikilitic microcline crystals have penetrated the amphibolite, and abundant myrmekitic overgrow ths have formed on plagioclase crystals in contact with microcline.

EE-3A core 4, as recovered, was about $30 \mathrm{ft}(9.1 \mathrm{~m})$ long and consists almost entirely of amphibolite. The amphibolite is mostly medium-grained, but there are fine-grained intervals as well. Preferred orientation of hornblende and biotite imparts a distinct schistosity to the rock.

Hornblende, in equant to elongate subhedral crystals, and equant, subhedral plagioclase $\left(\mathrm{An}_{36-45}\right)$ are the most abundant minerals. Biotite, iron oxide, and pyrite are present in subsidiary amounts, and apatite and rare to minor anhedral sphene are accessory minerals. The main secondary mineral is prehnite, as alteration of plagioclase or biotite and as fracture fillings. Chlorite also is a common alteration product of biotite. Minor epidote, calcite, and actinolite are alteration products of biotite, plagioclase, and hornblende. Sphene and secondary plagioclase are rare fracture fillings.

The junk basket amphibolites from EE-2 are mineralogically more varied than the amphibolites in the EE-3A cores. Some pieces from the EE-2 11,100 ft junk basket return are es sentially similar to the EE-3A material, but several pieces contain no plagioclase or quartz. One fragment consists of amphibole and biotite, with accessory opaques, anhedral sphene, and apatite; another contains mostly amphibole, with clots and isolated crystals of salitic clinopyroxene.

In the absence of outcrop exposures, it is difficult to determine the origins of amphibolites from the Fenton Hill drill holes with certainty. The rocks have typical metamorphic textures and may represent xenoliths of metamorphic country rock incorporated into the granodiorite plutons. A less likely alternative is that the inclusions could be igneous rocks (or partially recrystallized igneous rocks) of unknown relationship to any of the silicic plutonic rocks encountered in the boreholes. The preferred orientation of hornblende and biotite in the rocks probably is a metamorphic fabric, but could be an igneous crystal settling or flow fabric. Similarly, the abundant triple-junction grain boundaries and simple crystal outlines could be the products of metamorphic solid-state 
recrystallization (Williams, Turner, and Gilbert, 1954) or textural equilibrium crystallization in igneous cumulate rocks (Hunter, 1987). The simplicity of the plagioclase twinning in the EE-3A amphibolite samples, with most grains showing only one set of polysynthetic twinning, and the absence of well-formed crystal shapes are more characteristic of metamorphic rocks (Williams, Turner, and Gilbert, 1954). These characteristics are in strong contrast to the multiple twinning and mostly subhedral morphology in the plagioclase of the granitic plutonic rocks.

\section{Biotite-Plagioclase Rock}

Intervals of fine-grained, variably-foliated rock containing mostly plagioclase and biotite have been identified in cuttings from EE-3 and -3A. None of the cores from EE-3A or the cuttings from EE-2A contain this rock type, but very similar rock was recovered in a core from EE-2

[12,848-12,856 ft $(3,916.1-3,918.5 \mathrm{~m})]$. The two-dimensional distribution data from EE-3A suggest that biotite-plagioclase rock partly envelops the amphibolite sampled in core 4 and, less certainly, the amphibolite in core 1. In EE-3, biotite-plagioclase rock underlies the thick amphibolite interval in the lower part of the hole [about 13,380 to $13,740 \mathrm{ft}(4,078$ to $4,188 \mathrm{~m})]$. This is the least understood rock in the Fenton Hill Precambrian section. Laney, Laughlin, and Aldrich (1981) described the biotite-plagioclase rock in the EE-2 core as a metamorphosed mafic volcanic or intrusive rock, but this interpretation is open to question. The designation "biotite-plagioclase rock" used in this report is appropriate for a rock of uncertain or hybrid origin. The textural relations between this unit and adjacent geologic units may be important keys to understanding the larger-scale geologic setting of the Phase II reservoir. For this reason, a detailed re-examination of the EE-2 core material was undertaken.

\section{EE-3A Cuttings}

Bit cuttings of the biotite-plagioclase rock from EE-3A contain highly variable proportions of plagioclase, quartz, biotite, and microcline as the main constituents, with variable lesser amounts of epidote, sphene, and hornblende. In the majority of cutting samples, the proportion of mafic minerals (biotite, hornblende, iron oxide, epidote, sphene) is larger than in the granitic rocks from the borehole. Grain size is generally less than $0.25 \mathrm{~mm}$. There is considerable variation in morphology and size of plagioclase crystals. Most have irregular lath or tabular shapes with length-to-width ratios up to $3: 1$. Some rock fragments contain more elongate plagioclase with length-to-width ratios greater than 4:1. Larger plagioclase crystals, up to $1 \mathrm{~mm}$ long and with complex twinning, are characteristic of some cuttings and absent from others. Bimodal textures with about 2 to $3 \%$ larger crystals also exist.

The larger plagioclase crystals show strong compositional zoning. In one cutting (EE-3A $12270-80 \mathrm{~B}$ ) with abundant large elongate laths, the crystals have core compositions as calcic as $\mathrm{An}_{43}$ and rims of about $\mathrm{An}_{23}$. The cores of the largest crystals are too highly altered to give reliable compositional data. Smaller plagioclase crystals in a plagioclase-poor cutting (EE-3A 12230-40) mostly have compositions in the $\mathrm{An}_{24-26}$ range, but may be as sodic as $\mathrm{An}_{5}$.

Quartz is present in amounts less than or approximately equal to the plagioclase content. Anhedral, equant quartz grains are either interstitial to the plagioclase or form a mosaic texture with plagioclase. Coarser-grained quartz also is locally present in myrmekitic intergrowths with microcline. Most of the myrmekite forms irregular patches, but a few patches have a square or rectangular outline suggesting replacement of an earlier phase. There are also a few coarser-grained, non-myrmekitic quartz-microcline aggregates. Individual crystals of microcline are generally fine-grained, and some are perthitic.

Biotite content varies from about 10 to $20 \%$. Preferred orientation of biotite crystals is common. Epidote is a ubiquitous constituent, present in amounts up to about 5\%. Many epidote crystals have small cores or zones of allanite. Sphene is present in quantities from about 1 to $5 \%$. The crystals are 
very irregularly-shaped and are partially poikilitic, enclosing small crystals of feldspar and quartz. In some of the cuttings, sphene crystals are surrounded by quartz-feldspar patches devoid of biotite, giving the rock a spotted appearance. Blue-green hornblende is present in most of the biotite-plagioclase rock cuttings studied. Subhedral to euhedral crystals of hornblende comprise up to about $3 \%$ of the rock. A small amount of hornblende is associated with sphene. Very fine-grained opaques and apatite crystals are present in quantities up to about $2 \%$ and $1 \%$, respectively.

The degree of alteration in the biotite-plagioclase rock is variable. Most large plagioclase crystals have a cloudy appearance and. some have heavily sausseritized cores. The finer-grained plagioclase tends to be less altered. Biotite, although mostly unaltered, is locally chloritized. Small amounts of sparry calcite are present in some cuttings.

\section{EE-2 Core 2}

The EE-2 core originally described by Laney, Laughlin, and Aldrich (1981) is the only intact sample of biotite-plagioclase rock recovered from Fenton Hill. The core contains rounded to angular masses of the fine-grained rock, ranging in size from about $1 \mathrm{~mm}$ to $40 \mathrm{~cm}$ or more, within a medium-grained, locally porphyritic biotite monzogranite (modal analysis by Laney, Laughlin, and Aldrich, 1981). The porphyritic character of the monzogranite distinguishes it from most granitic rocks examined in this study. Another difference is the common presence of Carlsbad twinning in microcline, indicating that the microcline formed by subsolidus inversion from orthoclase.

The masses of biotite-plagioclase rock in the core have the appearance of partially assimilated xenoliths or of mafic magma injected into or otherwise mixed with a more silicic magma and subsequently broken up by movement of the silicic magma (e.g., Compton, 1962; Hill, 1988). The fine-grained rock is essentially similar in texture and mineralogy to the biotite-plagioclase rock in EE-3 and -3A. The spotted texture of poikilitic sphene crystals surrounded by felsic minerals, described above, is especially well-developed near the margins of the biotite-plagioclase rock masses. Sphene crystals along the margins are larger than in the interiors of the biotite-plagioclase rock masses and have the best-developed poikilitic morphology, enclosing small, euhedral plagioclase or biotite crystals. Iron oxide is commonly associated with the sphene. Other locally-developed features along the margins of the biotite-plagioclase rock masses include concentrations of biotite and iron oxide, rare aggregates of epidote and anhydrite, and poikilitic microcline with inclusions of euhedral plagioclase or biotite.

\section{a. Plagioclase}

Groundmass plagioclase compositions in the biotite-plagioclase rock of EE-2 are comparable to those in the similar rock from EE-3A. The majority of analyses for both holes .are in the $\mathrm{An}_{23-36}$ range, with a few outlier values. This range matches groundmass plagioclase compositions in the EE-2 monzogranite surrounding the biotite-plagioclase rock, as well as EE-3A granodiorite, tonalite, and magmatically modified amphibolite. Most EE-3A monzogranites and leucogranites have more sodic plagioclase.

There are at least two textural populations of large $(\geq 0.2 \mathrm{~mm})$ plagioclase crystals in the biotite-plagioclase rock of EE-2. One population consists of elongate plagioclase laths similar to those in the EE-3A cuttings. The laths in section EE-2 12849-3 are less than $0.5 \mathrm{~mm}$ long and range from about $\mathrm{An}_{35}$ to $\mathrm{An}_{24}$, with normal compositional zoning. In section EE-2 12852-1C, well-formed laths 0.3 to $0.8 \mathrm{~mm}$ long comprise about $5 \%$ of the rock. The laths are zoned within the range of $\mathrm{An}_{47-31} \cdot$. Crystals commonly contain multiple sets of simple and complex twins. Extremely fine dusty alteration, commonly concentrated in certain growth zones, is typical; 
sericitization is less common. Some laths contain a few scattered mafic mineral inclusions or more abundant inclusions concentrated in the cores of the host crystals.

The second population of large plagioclase crystals differs from the first in morphology, twinning, composition, degree of alteration, and textural arrangement. These crystals also are well formed, but are mostly subequant prisms rather than elongate laths. The overall abundance of the prismatic crystals is less than $1 \%$. Two possible subgroups have been identified. One subgroup exhibits Carlsbad twinning or albite twinning with a small number of polysynthetic twin lamellae, and the crystals are mostly unaltered. The range of compositional zoning within individual crystals is not large $\left(\mathrm{An}_{22-29}\right)$. Many of the plagioclase crystals contain zonally-arranged, abundant inclusions of very small ( $<0.05 \mathrm{~mm}$ ) euhedral biotite, opaque, and minor amphibole crystals. The inclusion zones are near the outer margins of the plagioclase crystals. In some, but not all, plagioclase prisms, the inclusion zones and/or the outer margins are more calcic than the interiors of the crystals. Also distinctive is the presence of highly rounded cores within many of the prismatic crystals.

Large plagioclase prisms of the second subgroup commonly have multiple sets of twins and are slightly to moderately altered. Mafic mineral inclusions are scattered in the interiors of the crystals. Oscillatory or reverse compositional zoning is strongly developed, with variations in a single 1.6-mm crystal from $\mathrm{An}_{51}$ to $\mathrm{An}_{29}$. Plagioclase crystals with morphology and compositional zoning similar to both subgroups are present in the monzogranites surrounding the biotite-plagioclase rock (12848-3A, 12849-3, 12853-2). The cores of the highly-zoned plagioclase prisms in the biotite-plagioclase rock and the surrounding monzogranites are much more calcic than measured plagioclase compositions in any of the plutonic rocks of EE-3A.

Laney, Laughlin, and Aldrich (1981) did not distinguish separate populations of large plagioclase crystals and described the crystals as either metamorphic porphyroblasts or relict phenocrysts crystals of igneous origin that survived the metamorphic recrystallization of a volcanic or intrusive rock. The euhedral morphology and strong discontinuous zoning of the large crystals are much more compatible with an igneous origin. The retention of compositional heterogeneity among subgroups of large crystals and the high anorthite content of some crystals both suggest that these are igneous crystals in an igneous rock rather than relict igneous crystals in a metamorphic rock because these attributes would not likely survive amphibolite-grade metamorphism.

One implication of the plagioclase studies is that the biotite-plagioclase rock was a product of magmatic crystallization rather than solid-state metamorphism. Additional evidence is examined in the following sections. A remaining question raised by the heterogeneity of the large plagioclase crystals is whether any might be xenocrysts derived from a source outside the biotite-plagioclase magma. The lightly-altered, elongate plagioclase laths are largely restricted to the biotite-plagioclase rock, with only rare crystals of similar aspect in the enclosing monzogranite (12853-2). These crystals are certainly in situ phenocrysts. The other varieties of large plagioclase crystals have extremely similar and more abundant counterparts within the monzogranite (12849-3, 12853-2) surrounding the biotite-plagioclase rock. Such crystals may therefore be monzogranite-derived xenocrysts incorporated into the biotite-plagioclase magma. The outer, mafic inclusion-rich zones on some large plagioclase crystals are probably overgrow ths acquired after the xenocrysts were incorporated into the mafic magma. Large, rounded quartz crystals and quartz-microcline aggregates in the mafic rock also may have come from the granitic magma.

\section{b. Sphene}

In addition to the abundant irregularly-shaped, poikilitic sphene crystals, the biotite-plagioclase rock also contains a very small number of larger and better-formed crystals similar in morphology to the subhedral and euhedral sphene in the monzogranites of core 2 (sections 12849-3 and 12853-2) and other Fenton Hill granitic rocks. A single euhedral 0.4-mm crystal of golden-yellow sphene in biotite-plagioclase rock section $12852-1 \mathrm{C}$ (Fig. 5) contains an average of $0.88 \mathrm{wt} \% \mathrm{Ce}_{2} \mathrm{O}_{3}$, 
0.59 wt $\% \mathrm{La}_{2} \mathrm{O}_{3}$, and 1.23 wt $\% \mathrm{Y}_{2} \mathrm{O}_{3}(\mathrm{n}=3)$. The average total $\mathrm{RE}_{2} \mathrm{O}_{3}$ content of this crystal is about $8.4 \mathrm{wt} \%$. The crystal is mantled by lower-REE sphene of similar color to the irregular, pale brown sphene crystals in the groundmass, which contain no detectable cerium and have average $\mathrm{RE}_{2} \mathrm{O}_{3}$ contents of about $2.2 \mathrm{wt} \%(\mathrm{n}=4$; Fig. 6).

The biotite-plagioclase rock of section 12851-4A contains one subhedral sphene crystal $0.6 \mathrm{~mm}$ long and of slightly different color from the irregularly shaped matrix sphene crystals that do not exceed $0.3 \mathrm{~mm}$. It is uncertain whether this crystal has been mantled by younger sphene like the crystal in section 12852-1C. The large crystal contains little or no cerium, but has an average REE content of about $4.7 \mathrm{wt} \%(\mathrm{n}=4)$. Matrix sphene crystals have average REE contents of $2.7 \mathrm{wt} \%$ $(\mathrm{n}=3)$, similar to the matrix crystals in section 12852-1C.

The combination of consistent textural and compositional differences between the irregularly shaped low-REE sphene and the well-formed higher-REE crystals requires different origins for the two varieties of sphene. The rarity of the higher-REE, well-formed crystals in an obviously Ti-rich rock with abundant irregular sphene suggests an exotic origin for the higher-REE crystals. Physical incorporation of xenocrysts would imply that the biotite-plagioclase rock once existed in a sufficiently liquid condition to allow in-mixing of foreign crystals. An alternate interpretation, based on a metamorphic origin for the biotite-plagioclase rock, might have the exotic sphene incorporated into the precursor rock and survive metamorphism as a relict xenocryst. This seems a less plausible interpretation because there is no evidence for survival of either primary or deuteric sphene that the original rock would likely have contained.

Possible relationships between the REE content of sphene and the type of rock containing the sphene have been investigated for many years. Zabavnikova (1957) found that sphene compositions rich in REE are characteristic of acid (e.g., granitic) rocks, whereas REE-poor compositions are typical of basic rocks, including amphibolites. Cerium is absent in sphenes from basic rocks and most abundant in acid pegmatites. Fleischer (1978) sought correlations within a database of 271 published analyses of sphenes mostly from plutonic rocks. The average total wt $\%$ $\mathrm{RE}_{2} \mathrm{O}_{3}$ is lower for mafic rocks than for other rock types, consistent with Zabavnikova's data, although all analyzed sphene samples from mafic rocks are cerium-bearing. Sphene samples containing as much as $8 \mathrm{wt} \% \mathrm{RE}_{2} \mathrm{O}_{3}$ (like the euhedral crystal in 12852-1C) are all from granites and granitic pegmatites. Rare-earth contents up to about $4 \mathrm{wt} \%$ (like the subhedral crystal in 12851-4A) are found in sphene from a wider variety of alkalic, intermediate, and silicic rocks (Fig. 7).

In light of the published compositional data, it seems likely that the euhedral sphene crystal in section 12852-1C originated in a granitic magma and was later incorporated as a xenocryst in a more mafic liquid. The REE content of the crystal most closely matches the compositions of sphene crystals in the monzogranites (EE-2 12849-3 and 12853-2) enclosing the biotite-plagioclase masses in EE-2 core 2. A xenocrystic origin for the subhedral crystal in section 12851-4A is neither supported nor precluded by the published data. The minor Ce content of the crystal is a point of greater similarity to Fenton Hill monzogranite sphenes than to the consistently non-cerian sphenes in the groundmass of biotite-plagioclase rock. The total $\mathrm{RE}_{2} \mathrm{O}_{3}$ of the subhedral crystal lies within the range of both monzogranite and biotite-plagioclase rock sphenes. 


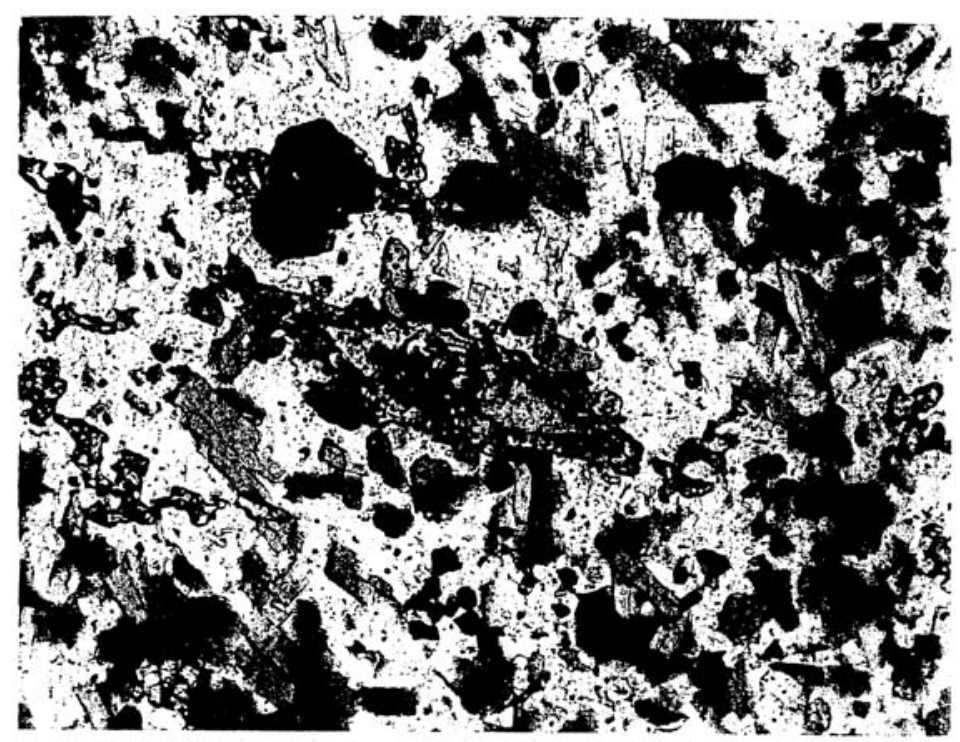

Figure 5. Euhedral sphene crystal with overgrowth, EE-2 12852-1C. Plane-polarized light, long dimension of figure is $0.8 \mathrm{~mm}$.

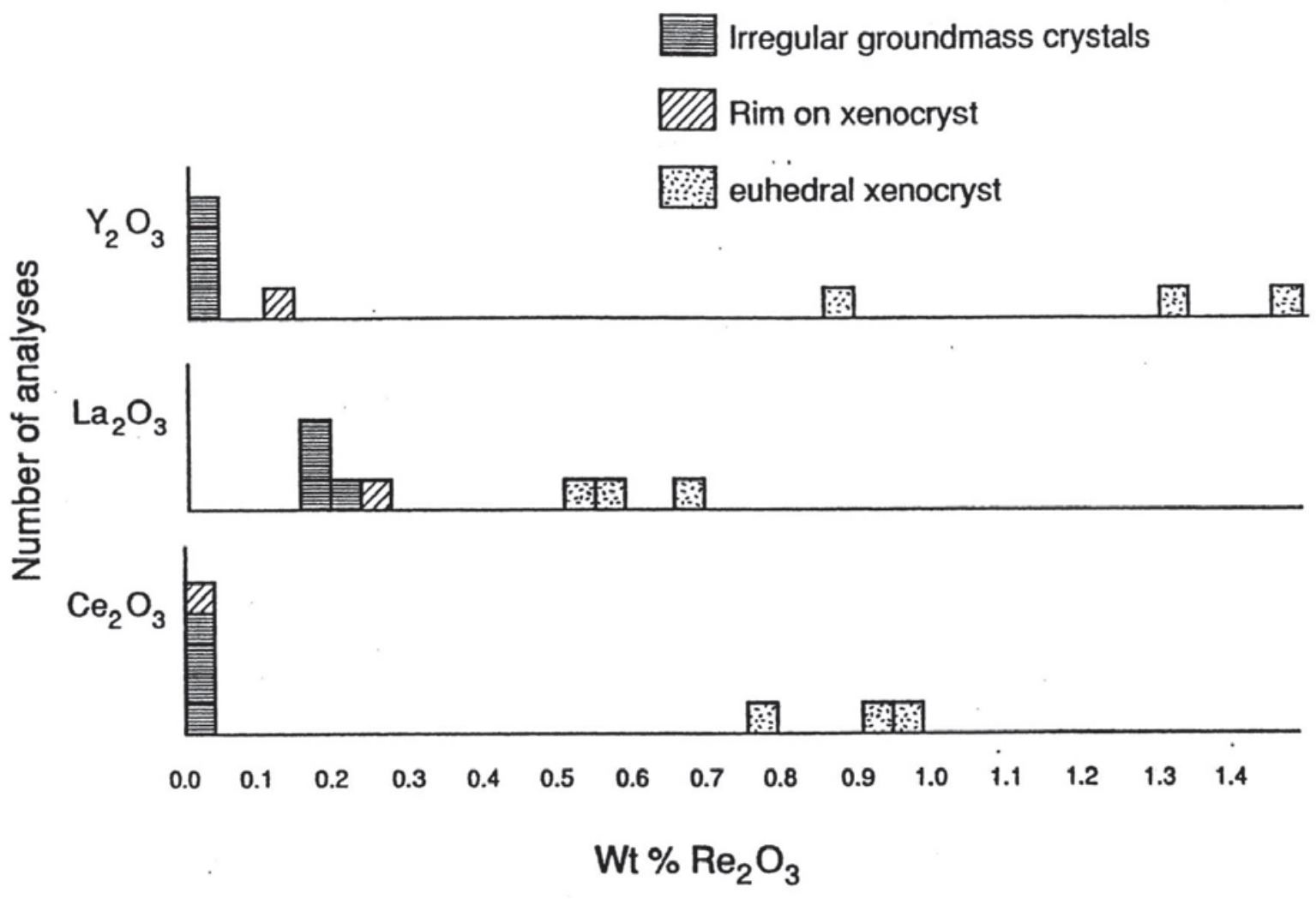

Figure 6. Rare-earth contents of sphene, EE-2 12852-1C. Each box represents one analysis. 


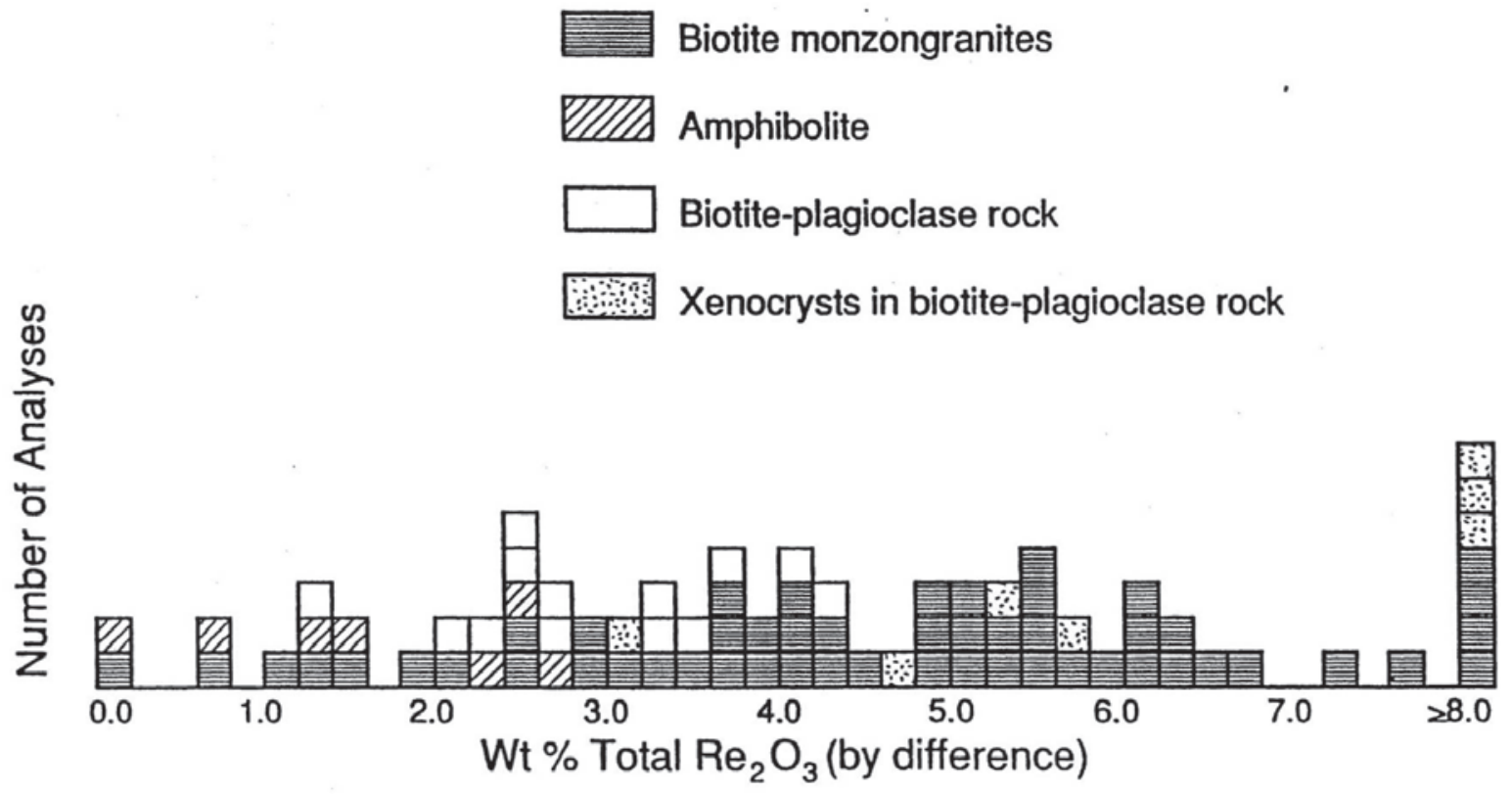

Figure 7. Rare-earth contents of sphene crystals in Fenton Hill rocks. Each box represents one analysis.

\section{c. Hornblende}

The biotite-plagioclase rock locally contains a few mafic aggregates composed predominantly of biotite. In section 12851-4A, the aggregates are up to $3 \mathrm{~mm}$ across, and the largest aggregate contains hornblende, epidote, calcite, opaques, quartz, and plagioclase in addition to biotite. The replacement of hornblende by biotite and other minerals in the aggregates is suggested by vermicular replacement textures in the biotite and tiny residual blebs of hornblende in quartz and feldspar very similar to those in granodiorite (EE-3A 11600-2) and tonalite (EE-3A 12438-14).

A comparison of compositional data for the hornblende in the mafic aggregates and in the groundmass with data for hornblende in amphibolites and biotite-plagioclase rock and residual hornblende in granitic rocks reveals noteworthy similarities and differences. The compositional range occupied by groundmass hornblendes in briotite-plagioclase rock is distinct from the more Mg-rich range characteristic of amphibolite hornblendes and residual hornblendes in granitic rocks. Groundmass hornblendes in 12851-4A have a restricted compositional range closely matching the range for hornblendes from other biotite-plagioclase rock samples. Data from a mafic aggregate cover as wide a range as all varieties taken together, including the most $\mathrm{Mg}$-rich amphibolite hornblendes. The mafic aggregate hornblendes have Ti values similar to hornblendes in the groundmass of biotite-plagioclase rocks and the residual hornblende blebs in granitic rocks rather than the higher values common to amphibolite hornblendes. The mafic aggregates may therefore be the compositionally modified remains of amphibolite xenoliths partly assimilated by the biotite-plagioclase rock parent magma.

\section{Origin and Significance of the Biotite-Plagioclase Rock}

The petrologic data in the preceding sections infer that the biotite-plagioclase rocks existed as a magma whose composition was modified by the addition of material from a co-existing granitic magma. The granitic magma was locally modified by mixing, as well, and compositional variability 
within the monzogranite suggests multiple mixing episodes. Assimilation of mafic metamorphic rock also may have contributed to the ultimate composition of the biotite-plagioclase rock.

There is a variety of possible sources for the mafic magma represented by the biotite-plagioclase rock. Eichelberger (1988) believes that most mafic inclusions in granites represent mafic magma injected into silicic magma chambers. Other potential sources include material remobilized from mafic border zones of granodiorite plutons or from portions of the granodiorite magma chamber containing mafic crystal cumulates. Fusion of mafic crustal rocks (Carmichael, Turner, and Verhoogen, 1974) or reaction zones formed around mafic xenoliths incorporated into granodiorite plutons might have been sources of mafic magma.

Rock-type distribution data for drill holes EE-3 and -3A seem to indicate a spatial association of biotite-plagioclase rock with the amphibolite xenolith zones. The amphibolites are either fragments of the country rock intruded by the granitic magmas or crustal material from greater depth incorporated and carried upward by the magmas. The coherent nature of the xenolith zones suggests local introduction of wall rock with less mixing than would have occurred during magma migration from a deeper source. Given such a case, the biotite-plagioclase rock and its enclosing monzogranite may have been portions of pluton border-zone magmas carried into the interior of the magma chamber along with large chunks of wall rock. Alternatively, one or both of the biotite-plagioclase and monzogranite magmas represented by EE-2 core 2 may have been genetically unrelated to the more abundant granodioritic magmas. In the absence of field exposures and additional geochemical data, neither alternative can be proven.

The mafic biotite-plagioclase rock represents a very small proportion of the rocks encountered in EE-2A and -3A. Biotite monzogranite of mixed origin, like that in EE-2 core 2, probably is present in the two sidetracked holes in unknown quantities. Even though it was not possible to determine the exact quantities and distributions of these hybrid rocks, the presence of such materials shows that the granitic rocks have had a complex history of multiple mixing episodes.

\section{ALTERATION}

All of the granitic plutonic rocks examined show typical deuteric alteration (alteration during the later stages of magma cooling). Most plagioclase crystals are cloudy, and some have been albitized or partly replaced by epidote, muscovite/sericite, and calcite. Microcline commonly is much less altered, with minor sericitization of perthite lamellae and patchy alteration to sericite or epidote (in leucogranite). Biotite is locally altered to various combinations of chlorite, sericite, and epidote. In leucogranite, biotite also may have been altered to muscovite and hematite.

The amphibolites have had a more complex history of alteration than the granitic rocks. Amphibolite alteration history cannot be fully documented, but probably has included retrograde metamorphism, multiple episodes of hydrothermal alteration, some of which were as sociated with dike intrusions, contact metamorphism and recrystallization during assimilation into granitic magma, and post-assimilation alteration. The effects of different alteration episodes probably overlap and are not necessarily represented by unique alteration or recrystallization products.

The most prominent retrograde reactions in amphibolite involved replacement of hornblende by biotite or by variable combinations of actinolite, epidote, prehnite, calcite, and opaques. Chloritization of biotite and sausseritization of plagioclase both seem to have been most intense adjacent to quartz-plagioclase dikes and veins, which also are altered.

Other mafic rocks have been altered in a similar manner to the granitic rocks. Minor sericitization of plagioclase is common, and alteration of the feldspar to fine-grained epidote is a local feature of biotite-plagioclase rock. There has been minor chloritization of biotite. Hornblende generally appears unaltered, except adjacent to some leucogranite dikes. 
The rocks are more highly altered around fractures and breccia zones, although the alteration products are mostly the same deuteric minerals. In the granitic rocks, feldspar crystals (especially plagioclase) adjacent to fractures have a pink to orange color (in hand specimen) from minute inclusions of iron oxide. Granodiorite in the main breccia zone is so highly crushed that iron oxide has penetrated the entire rock, making it bright orange. There is no clear textural evidence to indicate the source of the iron oxide, but alteration of biotite was a possible source.

\section{A. Reassessment of Alteration Zones in EE-2}

When the lower part of EE-2 was being drilled through the Precambrian granitic rocks, many cutting samples consisted largely or entirely of non-granitic material. Laney, Lauglin, and Aldrich (1981) interpreted the material as representing heavily altered granitic rock from faults and shear zones.

It is difficult to explain why this EE-2 material bears no resemblance to any of the altered and brecciated granitic rocks in the better-quality cuttings from EE-3A and $-2 \mathrm{~A}$. The existence or nonexistence of alteration zones has been used as a criterion to help determine drilling trajectories and may also be a factor in interpreting geophysical data. Therefore, new thin sections of the material in question were prepared to replace the original sections, now missing, studied by Laney, Laughlin, and Aldrich (1981). Study of the new thin sections indicates that the published descriptions are accurate, but the unusual samples did not come from the depths they were supposed to represent.

The non-granitic material is basically similar in all samples examined and consists of clastic sedimentary rock fragments. The most common varieties contain fine quartz sand grains in a matrix with variable proportions of clay and carbonate. Fossil carbonate shell fragments are present but not abundant.

The unusual cuttings were compared with samples from the Paleozoic section of drill hole VC-1, located about $7 \mathrm{~km} \mathrm{SE}$ of Fenton Hill. This is a continuously cored hole, so there is little uncertainty about sample depths. There are strong textural and mineralogical similarities between the EE-2 material and locally fossiliferous sandy mudstones and claystones of the Sandia Formation and Madera Limestone in VC-1. These similarities suggest that the non-granitic material from EE-2 is contamination from the Paleozoic section overlying the Precambrian rocks.

\section{FRACTURES}

One of the goals for geologic study within the Hot Dry Rock project was to investigate the fractures that provide hydraulic connections between the drill holes. It was assumed by many project participants that the hydraulic fracturing experiments to create connections between the holes succeeded by reopening existing natural fractures, and the studies reported here tend to confirm this concept. The results of geologic fracture research are presented here as a series of topical studies designed to investigate large-scale patterns of fracture distribution, geologic associations and ages of fractures, differences in fracture development among rock types, and evidence of recent fracture-mineral deposition. With this information, it may be possible to correlate aspects of the geologic setting of fractures with the geometry and transmissive behavior of the geothermal reservoir.

The locations and orientations of the transmissive fractures have been inferred from microseismic data analysis, temperature logs, and borehole acoustic televiewer images. These are indirect techniques, and each technique detects a potentially different subset of all fractures. Results from these studies were compared to the fracture data from geologic samples, which present a more comprehensive picture of fracture distribution but do not distinguish fractures by geophysical character. 
Fractures were examined in cores and in cutting samples with average cutting sizes greater than about $0.5 \mathrm{~mm}$. Because most of EE-3A and all of EE-2A are represented only by cuttings, information about variations in fracture abundance and mineralogy with depth must come from cuttings. Detailed studies of cores provided information about possible relative ages and distinctive textural characteristics of fractures. Orientation data for fractures in cores are open to question because of malfunctions in the core-orienting equipment and because of large discrepancies between the mechanical core orientations and core orientations determined from remnant magnetism (Dey, 1985).

\section{A. Main Breccia Zone}

The main breccia zone, an interval of intensely brecciated rock, is the most prominent structural feature identified in the sidetracked holes. Because this zone has not been successfully cored, little is known about its macroscopic character or mechanical properties. The breccia zone was identified in cuttings from all the deep drill holes at Fenton Hill-EE-2A, EE-3A, EE-2, and EE-3 (Table V). A shallower hole, EE-1, intersected only the upper part of the breccia zone. Data for EE-1 and EE-3 are less precise because of poorer sample quality, and the EE-2 sample set is too incomplete to provide useful depth data. The boundaries of the zone tend to be gradational, making it difficult to establish their exact locations. The apparently greater thickness of the zone in EE-2A is really more a reflection of a locally increased intensity of brecciation and alteration that makes the zone easier to recognize in this hole. Because the thickness of the zone is large relative to the spacing between the drill holes, it is not possible to determine an accurate overall orientation. The lower boundary of the zone is slightly less irregular and perhaps less steeply inclined than the upper boundary. The zone is a relatively low-angle feature at Fenton Hill, with unknown amount and sense of offset.

\begin{tabular}{|l|l|l|}
\hline \multicolumn{2}{|c|}{ Table V. Main Breccia Zone Depth Intervals } \\
\hline \multicolumn{1}{|c|}{ Drill Hole } & \multicolumn{1}{|c|}{ Drilling Depth (ft/m) } & \multicolumn{1}{c|}{ True Vertical Depth (ft/m) } \\
\hline EE-1 & $9,960-? / 3,036-?$ & $9,960-? / 3,036-?$ \\
\hline EE-2A & $10,090-10,940 / 3,075-3,335$ & $9,974-10,784 / 3,040-3,287$ \\
\hline EE-3 & $10,720-11,020 / 3,268-3,359$ & $10,428-10,676 / 3,179-3,254$ \\
\hline EE-3A & $10,440-10,700 / 3,182-3,261$ & $10,232-10,485 / 3,119-3,196$ \\
\hline
\end{tabular}


Most of the rocks within the breccia zone are granodiorite, but granites, leucogranites, and amphibolite xenoliths within the zone have been affected as well. The distinguishing characteristics of the breccia zone in bit cuttings are the presence of thin (up to about $2 \mathrm{~mm}$ wide or more) veinlets of microbreccia and the intense orange alteration of the granitic rocks. Microbreccia is aphanitic and is light to dark green or dark red. Cutting samples from the microbreccia zone contain up to about $40 \%$ microbreccia (e.g., EE-2A 10530-40) in addition to abundant discrete fractures.

Microbreccia veinlets contain pulverized granodiorite and in situ secondary minerals. The secondary minerals are the same as the deuteric and hydrothermal alteration products characteristic of altered granitic rocks throughout the section: chlorite, epidote, calcite, hematite, quartz, and sericite.

\section{B. Fractures in Drill Cores}

\section{Fractures in EE-3A Core 1}

Fractures are common in both the host amphibolite and the leucogranite dikes, and are of two varieties. Older fractures, present predominantly or only in the amphibolite, generally follow the foliation. These fractures are of variable width and have poorly defined boundaries. Amphibole, plagioclase, and minor quartz microbreccias, with deformed biotite crystals, are common along the fractures. The most abundant secondary mineral filling fractures is potassium feldspar, as aggregates of small discrete crystals, as overgrowths on adjacent primary crystals, and as fracture linings of euhedral dog-tooth crystals. Fracture fillings of dog-tooth potassium feldspar also are present in the recrystallized amphibolites of the two deepest GT-2 cores [9,519-9,537 ft $(2,901-2,907 \mathrm{~m}) ; 9,607-9,609 \mathrm{ft}(2,928-2,929 \mathrm{~m})]$. The EE-3A core 1 fractures also contain chlorite in small veinlets between breccia clasts.

Younger fractures are filled exclusively with calcite. These factures are narrow, with sharp, well-defined boundaries, and cut both the amphibolite and the leucogranite dikes. Locally, the fractures may follow older fractures or the cleavages of biotite crystals aligned with the amphibolite foliation. Sparry calcite also fills the central cavity of a dog-tooth feldspar-lined fracture.

\section{Fractures in EE-3A Core 2}

This leucogranite core contains the most macrofractures per unit length of any core recovered at Fenton Hill. Fracture-filling minerals include plagioclase, quartz, sericite, hematite, and calcite. Cross-cutting fracture relationships indicate that plagioclase and, perhaps, quartz and sericite fill the older fractures, with hematite and calcite in younger fractures and reactivated segments of older fractures.

The manner in which older fractures were filled depended on the minerals that the fractures traversed. Fractures cutting across plagioclase crystals were completely filled by plagioclase in optical continuity with the host crystals. Plagioclase microbreccia was reincorporated into the original crystals by the newly deposited plagioclase. Fracture segments in quartz crystals were almost completely healed by deposition of new quartz in optical continuity with the host crystals and are nearly invisible or traceable only as discontinuous bubble trains. Some fracture segments in quartz were filled by plagioclase in optical continuity with adjacent plagioclase crystals.

There is no evidence of secondary microcline filling fractures in microcline or any other mineral. Most fracture segments in microcline crystals were incompletely filled with aggregates of fine-grained sericite; plagioclase and quartz fillings are less common. Because the sericite, plagioclase, and quartz fracture fillings are texturally and mineralogically distinct from the host microcline, fracture segments within microcline are much less thoroughly healed than in plagioclase and quartz. This variation in fracture fillings along fractures has given some of the older 
fractures - those that have not been reactivated-a discontinuous character. Many of the older fractures have been reactivated, and the preservation of unhealed fracture segments in microcline may have helped localize new fracturing activity along the old fracture traces.

In a few areas within microbreccia zones, displacement (and, possibly, dissolution) along fractures produced small gaps. The gaps were partly filled by euhedral, tabular plagioclase crystals $\left(\mathrm{An}_{0.2-0.4}\right)$ up to about $0.4 \mathrm{~mm}$ long and local overgrow ths on plagioclase crystals adjacent to the fractures. Most remaining void space was filled with calcite or hematite.

Compositional differences between fracture-filling plagioclase and the primary plagioclase crystals adjacent to fractures have been obscured by alteration. Primary plagioclase in this rock originally was at least as calcic as $\mathrm{An}_{12-14}$, but local deuteric alteration changed the compositions. Alteration was nearly complete in the vicinity of fractures, leaving cloudy plagioclase crystals with compositions in the range $\mathrm{An}_{1-5}$. The plagioclase fracture fillings, in optical continuity with adjacent or host plagioclase crystals, are generally less calcic $\left(\mathrm{An}_{0-2}\right)$ than the altered primary crystals. It is not clear whether this difference is original or is the result of more thorough alteration of fracture fillings that were originally more calcic. This compositional range also partly overlaps the ranges of the slightly less calcic, euhedral, void-filling plagioclase.

Plagioclase fracture fillings, other than euhedral crystals, can be divided into two groups based on degree of visible alteration. Just as the primary plagioclase has a pitted and cloudy appearance from deuteric alteration, so also do most of the plagioclase fracture fillings. As noted above, pitted plagioclase filled in both primary plagioclase and quartz along the oldest fractures. Plagioclase fracture fillings within microcline crystals are rare, for reasons discussed below.

In contrast to the fracture fillings of pitted plagioclase are plagioclase fillings with a clear appearance. Such fillings are relatively uncommon and are restricted to a few fractures, from which pitted plagioclase fracture fillings are absent. The clear fracture fillings seem to be related to the equally clear albite rims on primary plagioclase crystals. The rims were deposited onto the plagioclase crystals by diffusion of albitic material derived from the subsolvus unmixing of adjacent microcline crystals during the cooling of the solidified dike magma. Fractures containing clear plagioclase fillings apparently formed during the period of feldspar unmixing and are younger than the fractures that contain pitted plagioclase.

Additional effects of feldspar unmixing are exemplified by a filled fracture traversing a large plagioclase crystals and an adjacent area of several small microcline crystals. The fracture segment within plagioclase contains pitted plagioclase in optical continuity with the host crystal, whereas the portion of the fracture in the microcline is poorly-defined and contains a little sericite. The large plagioclase crystal also has a pitted appearance except in the clear albitic rim adjacent to the microcline crystals, a product of subsolvus unmixing in the microcline. During unmixing, the grain boundary between the microcline and plagioclase crystals migrated from its original position now marked by the interior boundary between pitted and clear plagioclase within the plagioclase crystal. As a result, the present plagioclase crystal is enlarged relative to its original size. The pitted plagioclase fracture filling within the clear plagioclase rim predates subsolvus unmixing and originally lay within the microcline crystals, but now lies entirely within the plagioclase crystal as a result of grain boundary migration.

The textural relations among feldspar grains and plagioclase fracture fillings indicate that the fractures must be very old. Fractures containing clear plagioclase fillings date to the period of initial cooling following plutonic emplacement. The pitted plagioclase fillings are present in still older fractures and may have been deposited from residual magma before the leucogranite was completely solidified. 
The calcite- and hematite-filled fractures do not contain any secondary plagioclase (except as noted above) and therefore postdate the periods of plagioclase deposition. Some of these fractures follow the traces of older fractures for at least several centimeters. Other fractures follow old fracture traces intermittently or not at all. Calcite is the most abundant filling in the younger fractures and also filled incompletely healed or reactivated segments of older fractures, void spaces in microbreccia, and the largest gaps in older fractures.

Hematite is a locally abundant fracture filling in both the younger fractures and the incompletely healed segments (mostly within microcline) of older fractures. In open fracture segments, the hematite forms $0.2-\mathrm{mm}$ rosettes. The hematite may have been derived from oxidation of biotite in the leucogranite.

\section{Fractures in EE-3A Core 3}

This core contains very few fractures. The granodiorite segment of the core contains a few short fractures (traces less than $1 \mathrm{~mm}$ long) that commonly follow cleavage traces in mineral grains. Fracture fillings include quartz (in optical continuity with neighboring quartz grains), epidote, chlorite, and calcite. The leucogranite contains one prominent slickensided fracture lined with epidote.

\section{Fractures in EE-3A Core 4}

The amphibolite contains a small number of prominent veins (quartz-plagioclase assemblage) up to $2 \mathrm{~cm}$ across and fractures, both parallel and at angles to the foliation. There is a more or less well-developed fabric of microcracks (about 0.2 - to $0.5-\mathrm{mm}$ spacings, transgressing grain boundaries), discordant to the amphibolite foliation, cutting both amphibolite and veins. Some fractures and veins are parallel to the microcrack fabric, and others are parallel to the amphibolite foliation. Fractures running along vein boundaries also are common.

The most abundant fracture-filling minerals, in both the amphibolite and the veins, are prehnite and chlorite. Quartz, plagioclase, and calcite fracture fillings are mostly confined to the veins, but the latter two minerals also fill a few fractures in the amphibolite proper. One prominent fracture cutting the amphibolite is locally coated with sphene. In fractures where prehnite is the main fracture-filling mineral, there is commonly a substantial amount of residual porosity. Figure 8 shows an area where several fractures intersect in quartz near the edge of a vein. The fracture in the upper left of the figure has been partly healed by deposition of new quartz, and the former extension of the fracture is marked by $<1$-micron round pores in the quartz. Platy prehnite filled most of the remaining fracture space, but considerable void space was left unfilled.

Prehnite-filled fractures with residual porosity also are present in a piece of amphibolite recovered from the 11,308-ft junk basket run in EE-2 (section EE-2 $11308 \mathrm{E}$ ). In this specimen, the pore spaces between prehnite crystals have been partly filled by feldspar, quartz, and calcite. These distinctive partly-open fractures might be mostly restricted to amphibolites in the deep drill holes, although sample coverage is too low to justify much certainty. The style of fracture filling in the amphiholite contrasts with the fracture-filling characteristics of the granitic rocks in which most fractures cutting quartz are completely filled with secondary quartz. In addition, calcite is a more common fracture filling in granitic rocks than in amphibolites. One possible explanation for these differences is that the amphibolites have not been in full communication with the hydrothermal solutions responsible for filling fractures in the granitic rocks. If most of the fractures in the amphibolite developed before it was incorporated into the granitic pluton, there would be some degree of discontinuity between the older fractures in the amphibolite xenoliths and younger fractures in the plutonic rocks. Alternatively, it may be that the individual pores in the prehnite-filled fractures are so lacking in connectivity as to minimize the invasion of calcite-saturated hydrothermal solutions. 


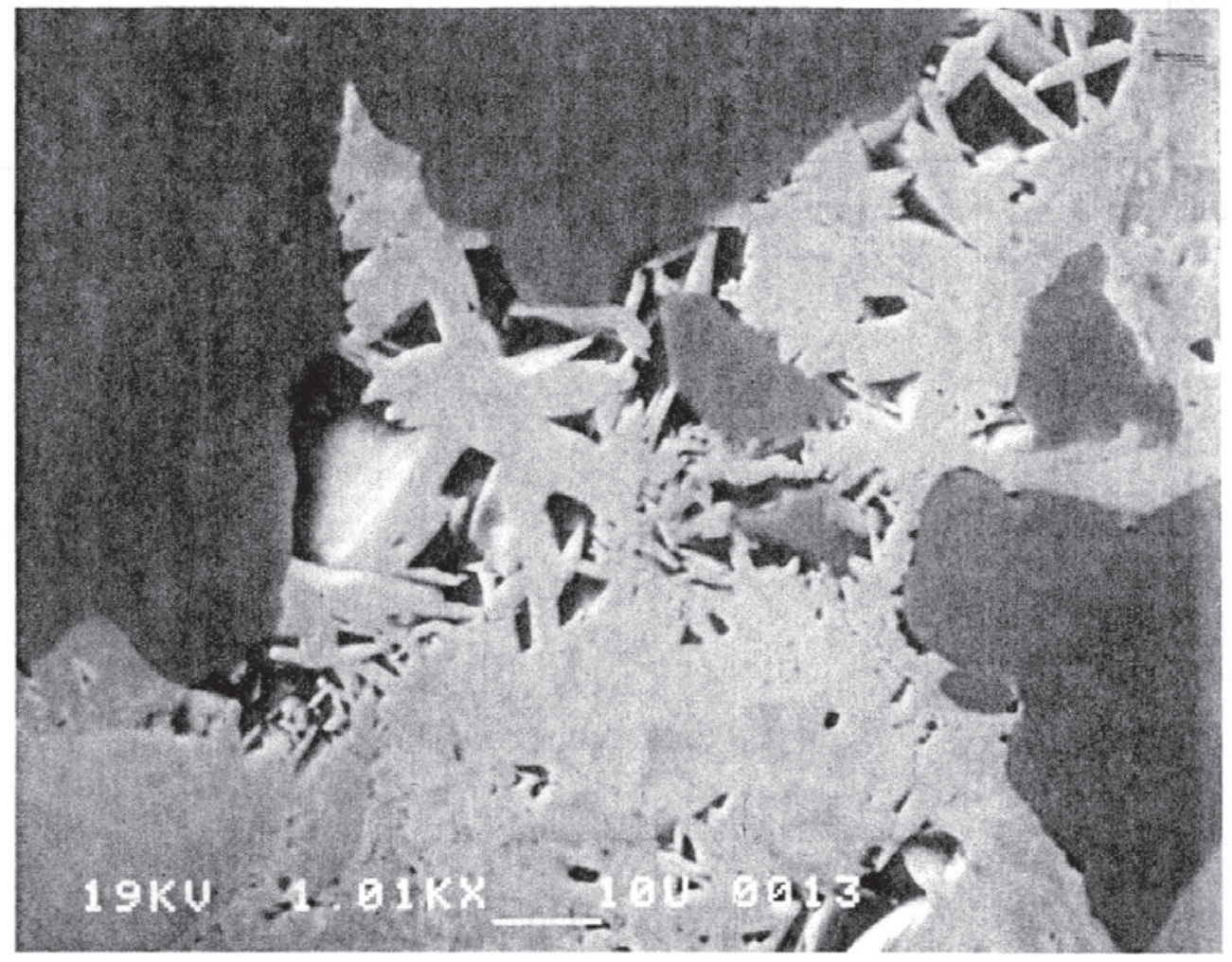

Figure 8. SEM back-scattered electron image of a fracture close to the margin of a small dike in amphibolite, EE-3A 12438-51A. Prehnite incompletely fills the fracture in a quartz grain, leaving some porosity. Scale bar is $10 \mu \mathrm{m}$.

\section{Characteristics of Fractures in Cuttings}

Fractures in cuttings from EE-2A and -3A were examined as time permitted. In general, the fillings in fractures from above and below the main breccia zone are similar to those observed in core specimens. Fracture fillings in granodiorites and biotite granites, the most common rock types although not well-represented in cores, include hematite, hematite-stained plagioclase, chlorite, epidote, and calcite. The following two sections describe specialized cutting fracture studies.

\section{Powdery Fracture Coatings}

A relatively rare type of fracture coating, identified in cuttings, has a distinctive powdery white appearance. One example of this coating was examined in detail as part of a study to investigate possible evidence of very recent mineral deposition in the reservoir fractures. There was a concern in the geothermal project that deposition of minerals from circulated fluids could reduce the permeability of fractures in the reservoir.

Powdery white fracture coatings were first observed in EE-3A cuttings from approximately the 9,700- to 9,900-ft (2,957 to 3,018-m) drilling depth interval, but nothing definite is known about the distribution of the material. A specimen of the white coating on a single fracture surface from the EE-3A 9810-20 cutting sample was studied by acid test, SEM imagery, and x-ray emission spectroscopy. The powdery coating consists of 100- $\mu \mathrm{m}$-long aggregates of calcite crystals scattered over an older fracture coating of potassium feldspar crystals. Calcite aggregates cover less than $50 \%$ of the fracture surface. The thickness of the calcite aggregates is about 10 to $20 \mu \mathrm{m}$. Individual 
calcite crystals are euhedral and mostly less than one micrometer across. The extremely small sizes of the calcite crystals distinguish these fracture coatings from other calcite fracture fillings in EE-3A. Calcite is a common fracture-filling mineral throughout most of the hole, but the crystals are typically in the 0.01 - to $0.1-\mathrm{mm}$ size range. Other components of the powdery aggregates, tentatively identified from energy-dispersive x-ray spectra, include minor barite $\left(\mathrm{BaSO}_{4}\right)$ and iron oxide or hydroxide. Because the crystals in the aggregates show no signs of growth interference from an opposite fracture wall, the local fracture aperture is estimated to have been more than 10 to $20 \mu \mathrm{m}$.

In addition to the aggregates of calcite crystals, a few crystals of a silica phase (probably quartz) have grown over the surfaces of older feldspar fracture coatings. Where silica and calcite are in close proximity, the silica is overlain by calcite and therefore is older.

The possible origins of the powdery fracture coatings fall into four general categories: 1) the coatings are of Precambrian age and are products of the modest deuteric and hydrothermal alteration experienced by the plutonic rocks during cooling, 2) the coatings formed during one or more hydrothermal events before the development of volcanic centers in the region, 3) the coatings are related in some way to thermal and hydrothermal processes associated with magmatic activity in the vicinity of the Valles caldera, 4) the coatings were deposited from fluids introduced during HDR drilling, hydraulic fracturing experiments, and circulation tests. There is at present no definitive evidence to support or eliminate any of these possibilities. Pertinent data are summarized in the following paragraphs.

The small sizes of the calcite crystals could be attributable to a relatively young age and/or highly restricted fluid circulation. In general, the sizes of calcite crystals in contact with fluids tend to increase over time; larger crystals grow at the expense of smaller crystals because smaller crystals have higher surface-to-volume ratios and are more easily dissolved. Another reason for grain size increase over time is the successive deposition of dissolved calcite onto seed crystals.

The inference of restricted fluid circulation is based on an assumption that greater fluid access would result in coarser crystallinity and more nearly complete filling of fractures with calcite. Partly-filled fractures with residual pore space have been observed in the Fenton Hill cores, as described in Section B. A feature common to the minerals (prehnite, quartz, potassium feldspar, calcite) in such fractures is that most crystals are at least $10 \mu \mathrm{m}$ across, and calcite crystals are up to $1 \mathrm{~mm}$ or more. This contrast to the extremely small crystal sizes in the powdery fracture coatings suggests a different origin and possibly younger age for the powdery calcite.

Fluid-inclusion studies of samples from GT-2 and EE-1 yielded data that may reflect the effects of magmatic activity in the Valles caldera region. Burruss and Hollister (1979) and Sasada (1988) determined the homogenization and melting temperatures of secondary fluid inclusions in Precambrian host rock quartz and both primary and secondary inclusions in vein calcite. They found that inclusions in quartz samples from depths between 1.5 and $3.0 \mathrm{~km}$ (bottom of EE-l) have re-equilibrated to thermal gradients higher than the present gradient. Inclusions in the calcite veins formed and re-equilibrated at temperatures equal to or lower than present-day borehole temperatures. This evidence for heating, cooling, and reheating is ascribed to the effects of magmatic activity in the Valles region, although no age data have yet been obtained to verify the connection.

The fluid inclusion melting temperature data reveal a wide range in salinity of inclusion fluids. In particular, Sasada's (1988) data show large differences in the salinity of inclusions along individual relict fractures. The compositional variability is taken as an indication that secondary inclusion fluids are mostly derived from recycling of pre-existing inclusion fluids and that the heating events 
were not associated with pervasive fluid circulation. This proposed scenario could be compatible with minor deposition of fine-grained calcite.

If one were to speculate about the locations of fractures where artificially-induced mineral precipitation would have been most likely to occur, a strong possibility might be recently reopened fractures that have received the largest cumulative volume of injected water or that have had the most contact time with introduced water. At the present, fractures in the Phase I reservoir may be the best candidates for having received the most water. The EE-3A 9,700- to 9,900-ft depth interval (2,900 to $2,958 \mathrm{~m}$ true vertical depth) brackets the depth of the EE-1 injection point $(2930 \mathrm{~m})$ for the 3/14/1978 hydraulic fracturing experiment (Pearson, 1981) and is about $230 \mathrm{~m}$ away from the injection point. This interval is more than $100 \mathrm{~m}$ away from the nearest microearthquake locations calculated for that experiment. However, many microearthquakes were located at equal or greater distances from the injection point, suggesting that water could have moved as much as $230 \mathrm{~m}$ away from the EE-1 wellbore.

In summary, it is not proved that the powdery calcite fracture coatings described in this section are either very young or are the products of crystallization from artificially-introduced water. There is some textural evidence to suggest that the fracture coatings represent the early stages of mineral deposition and may therefore be used as examples of new deposition that might occur in recently reopened fractures. If the mineral deposition was related to creation of the Phase I reservoir, then the powdery fracture coatings represent up to ten years' worth of deposition.

\section{Fracture Cutting Counts}

The objective of the fracture cutting-count studies was to obtain the best approximation to a continuous record of vertical variations in fracture abundance. The original goal was to accumulate fracture abundance data for all of EE-2A and -3A, but this could not be accomplished in the time available.

Each cutting sample examined for the fracture study was approximately equivalent in volume to a 5,000-cutting sample with 2-mm cutting size. Cuttings containing fractures were separated from selected cutting samples and counted. The semiquantitative results are roughly proportional to the amount of fracture surface with mineral coatings intersected by the borehole volume in a given interval. Fractures without mineral coatings or altered borders would not be detectable but are rare, based on core examination. In addition, the approximate relative abundances of various fracture fillings and coatings were determined for each sample examined.

Figures 9 and 10 show the fracture-cutting-abundance data for drill holes EE-3A and EE-2A (Appendix C). The cutting-abundance values were not corrected to account for cutting sizes other than $2 \mathrm{~mm}$. In addition, absolute fracture count amounts are not comparable between drill holes because the cuttings in drill hole EE-3A generally are larger than those in EE-2A. This means that a cutting sample from EE-3A would contain fewer (but larger) fracture cuttings than a sample from EE-2A with an equal amount of fracture surface.

Highly fractured intervals in EE-2A and -3A help define the main breccia zone identified in both holes. Fracture counts in the breccia zone underrepresent the true fracture abundances because individual fractures merge and lose their identities within the microbreccia veinlets. The incomplete data for EE-2A show a downward change at a little above 11,000 ft from a generally high fracture abundance typical of the main breccia zone to a lower overall fracture abundance with isolated highly fractured intervals. Figure 10 combines fracture abundance data with data on the abundance of leucogranite, a common dike rock, for the 10,700- to 12,200-ft drilling depths in EE-2A. Most of the highly fractured intervals are associated with dikes: 11,780 to $11,815,11,940$ to 11,945 , 12,025 to 12,050 , and 12,130 to $12,160 \mathrm{ft}$. One exception is the 11,650- to 11,665-ft interval, which is highly fractured but contains no leucogranite. 


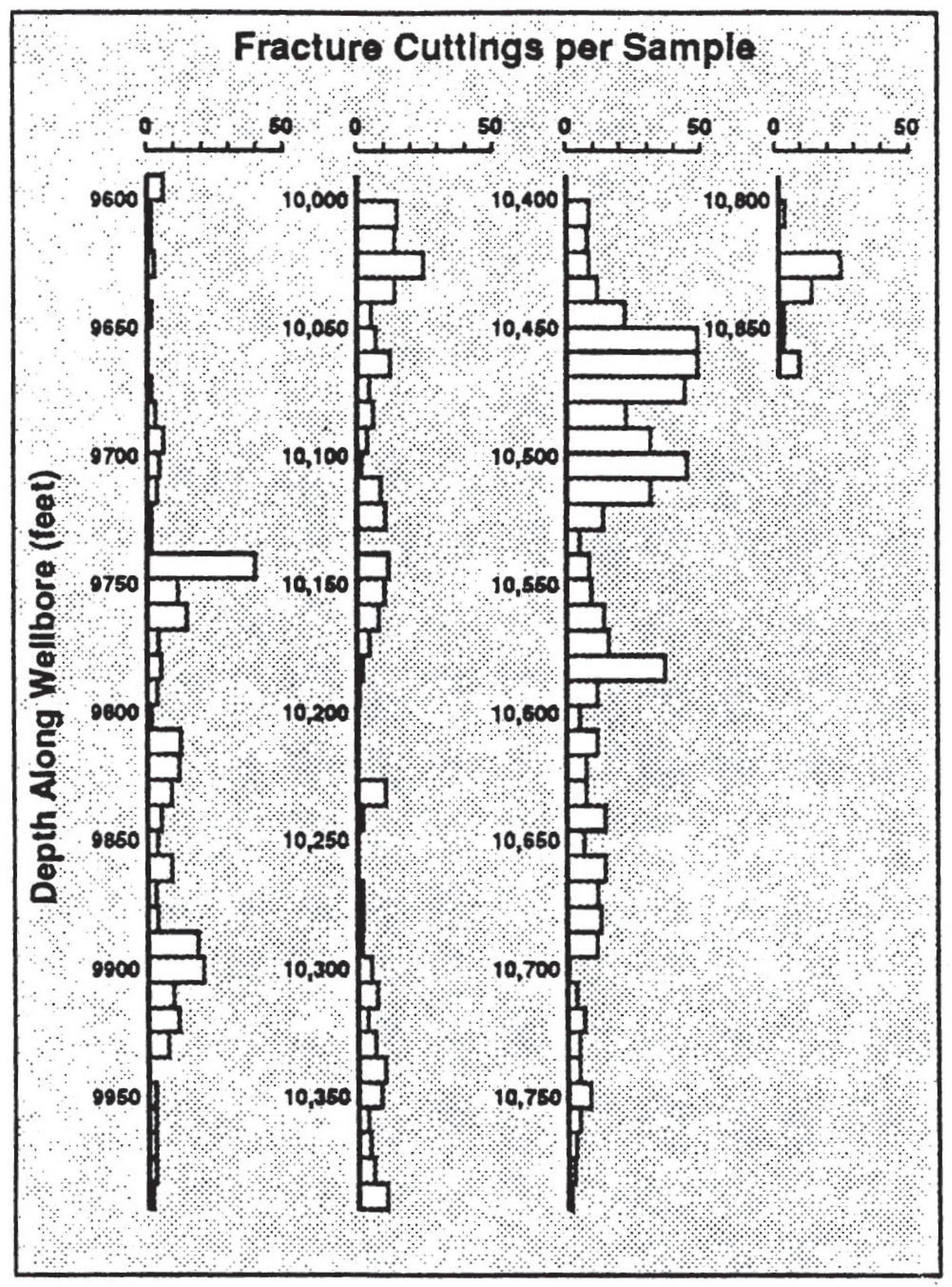

Figure 9. Fracture counts for cuttings from the upper part of EE-3A. Blank intervals represent no data. 


\section{EE-2A}
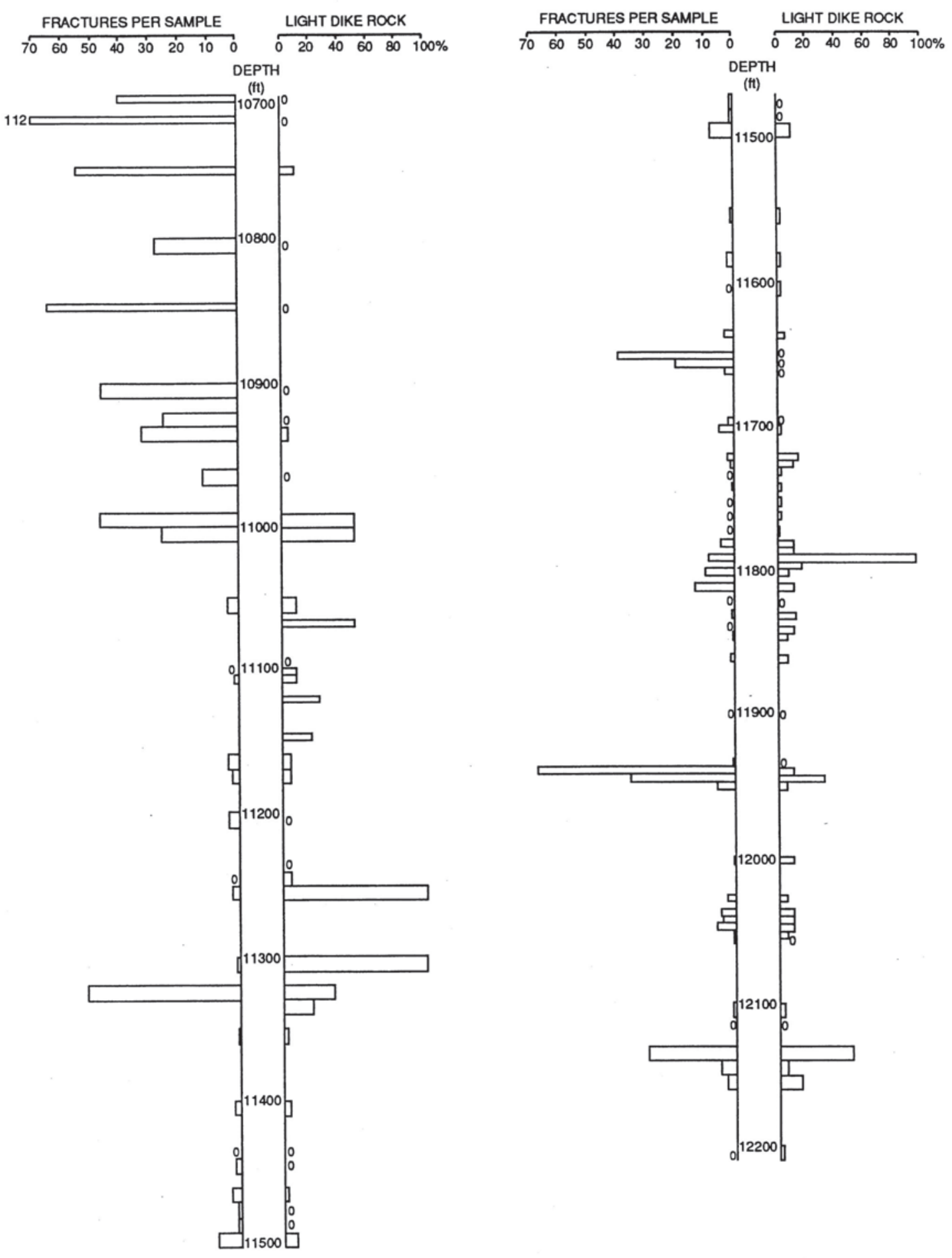

Figure 10. Fracture counts and leucogranite dike rock abundance in cuttings from EE-2A. Blank intervals represent no data. 
The fracture cutting counts were begun partly in the hope that planar zones of microseismicity identified from seismic data collected during fracturing experiments could be matched to certain intervals with high fracture counts. This would not only help confirm the existence of the planes, but would also make it possible to look for mineralogic or textural features characteristic of transmissive fractures. Preliminary comparisons of fracture counts and seismic data showed some promise; for example, at least one of the seismic planes intersects EE-3A within the highly fractured main breccia zone (Fehler, 1987a, 1987b). Although the fracture counts were not completed, it now appears less likely that precise correlations can be made. The main reason for this is that fractured intervals identified from cutting counts are too numerous or too closely spaced to make unique, unequivocal correlations with seismic planes. Uncertainties in the locations of seismic events (Fehler, House, and Kaieda, 1987; House, 1987) also limit the potential for correlation.

It does seem possible to make one significant conceptual correlation in addition to the seismic plane-breccia zone match described above. The three-point method used to identify planes in seismic data picks the best-defined plane first (Fehler, House, and Kaieda, 1987). This plane contains the largest number of three-event combinations whose uniform orientations define the plane. The trajectory of the EE-2A wellbore was selected to intersect the first plane picked from the massive hydraulic fracturing data, close to the greatest density of seismic event locations. The intersection of the best defined seismic plane and the EE-2A wellbore lies within a distinct region, described above, where most fractures are associated with leucogranite dikes. Because a dike is typically a thin, tabular body, seismic events along fractures confined to the dike would probably have a more nearly planar distribution than seismicity along a nonconfined fracture network. It is also probable that a dike has greater long-dimensional continuity than individual fractures. This provides the potential for seismic events along a dike-confined fracture system to maintain a consistent planar orientation over a larger area. Without attempting a correlation between the seismic plane and any particular dike or dike set, I would suggest that the geometric attributes of dike-confined fracture systems may have contributed to the strongly planar patterns of seismicity detected in this region by the three-point method.

\section{CONCLUSIONS}

The rock penetrated by wells EE-2A and $-3 \mathrm{~A}$ belongs to one or more generally granitic to granodioritic plutons. The plutonic rock contains two major xenolith zones of amphibolite, locally surrounded by partial envelopes of fine-grained mafic hybrid rock. Mineralogic and textural relations in EE-3A cores (also EE-2 and GT-2 cores) suggest a complex history of interaction between silicic magmas and between amphibolites and silicic magmas. A variety of hybrid rocks resulted from these interactions. The granodiorite is cut by numerous leucogranite dikes that diminish in abundance with increasing depth.

The most prominent structural feature identified in cuttings from all the deep wells is the main breccia zone, in which the rock is highly fractured and moderately altered. This zone is at least $75 \mathrm{~m}$ thick and is of uncertain but near-horizontal orientation. Fracture abundance generally decreases with increasing depth below the main breccia zone. In about the lower $183 \mathrm{~m}$ of EE-2A, incomplete data indicate that fractures tend to be associated with leucogranite dikes. One or more of these fracture systems confined by dikes probably correspond to the best defined plane(s) identified from seismic data collected during a fracturing experiment. This association suggests that at least some of the fractures providing access to the reservoir are of Precambrian age or have long-range orientations controlled by the orientations of Precambrian-age granitic dikes.

\section{REFERENCES}

D. Brookins, R. Forbes, D. Turner, A. Laughlin, and C. Naeser, "Rb-Sr, K-Ar, and Fission-Track Geochronological Studies of Samples from LASL Drill Holes GT-1, GT-2, and EE-1," Los Alamos Scientific Laboratory report LA-6829-MS (June 1977). 
D. Brookins and A. Laughlin, "Rb-Sr Geochronologic Investigation of Precambrian Samples from Deep Geothermal Drill Holes, Fenton Hill, New Mexico," J. Volcanology and Geothermal Res. 15, 43-58 (1983).

M. Brown, R. Duffield, C. Siciliano, and M. Smith, editors, "Hot Dry Rock Geothermal Energy Development Program Annual Report, Fiscal Year 1978," Los Alamos Scientific Laboratory report LA-7807-HDR (April 1979).

R. Burruss and L. Hollister, "Evidence from Fluid Inclusions for a Paleogeothermal Gradient at the Geothermal Test Well Sites, Los Alamos, New Mexico," J. Volcanol. Geotherm. Res. 5 163-177 (1979).

I. Carmichael, F. Turner, and J. Verhoogen, Igneous Petrology (McGraw-Hill, Inc., New York, 1974), 739 pp.

R. Compton, Manual of Field Geology (John Wiley and Sons, Inc., New York, 1962), 378 pp.

T. Dey, "Fracture Orientations from Last Two Cores and USGS Televiewer," Los Alamos National Laboratory memorandum ESS-3-1104-85 (November 1985).

J. Eichelberger, "Volcanic Equivalents of Mafic Inclusions in Granites," Eos Trans. AGU 69, 1495-1496 (1988).

M. Fehler, "Application of the Three Point Method to Experiment 2032: Results," Los Alamos National Laboratory memorandum ESS-4-87-32 (February 1987a).

M. Fehler, "Intersections of Seismic Planes with Boreholes," Los Alamos National Laboratory memorandum ESS-4-87-64 (March 1987b).

M. Fehler, L. House, and H. Kaieda, "Determining Planes Along Which Earthquakes Occur: Method and Application to Earthquakes Accompanying Hydraulic Fracturing," J. Geophys. Res. 92, 9407-9414 (1987).

M. Fleischer, "Relation of the Relative Concentrations of Lanthanides in Titanite to Type of Host Rocks," Am. Mineral. 63, 869-873 (1978).

R. Hill, "San Jacinto Intrusive Complex 1. Geology and Mineral Chemistry, and a Model for Intermittent Recharge of Tonalitic Magma Chambers," J. Geophys. Res. 93, 10,325-10,348 (1988).

L. House, "Locating Microearthquakes Induced by Hydraulic Fracturing in Crystalline Rock," Geophys. Res. Lett. 14, 919-921 (1987).

R. Hunter, "Textural Equilibrium in Layered Igneous Rocks," in Origins of Igneous Layering, Ian Parsons, ed. (D. Riedel Publishing Company, Dordrecht, The Netherlands, 1987) pp. 473-504.

R. Laney, A. Laughlin, and M. Aldrich, Jr., "Geology and Geochemistry of Samples from Los Alamos National Laboratory HDR Well EE-2, Fenton Hill, New Mexico," Los Alamos Scientific Laboratory report LA-8923-MS (July 1981).

A. Laughlin, and A. Eddy, "Petrography and Geochemistry of Precambrian Rocks from GT-2 and EE-1," Los Alamos Scientific Laboratory report LA-6930-MS (August 1977). 
A. Laughlin, A. Eddy, R. Laney, and M. Aldrich, Jr., "Geology of the Fenton Hill, New Mexico, Hot Dry Rock Site,” J. Volcanology and Geothermal Res., 15, 21-41 (1983).

C. Pearson, "The Relationship between Microseismicity and High Pore Pressures During Hydraulic Stimulation Experiments in Low Permeability Granitic Rocks," J. Geophys. Res. 86, 7855-7864 (1981).

M. Sasada, "Fluid Inclusion Evidence for Recent Temperature Rising at Fenton Hill Hot Dry Rock Test Site West of the Valles Caldera, New Mexico, USA," in Exploration and Development of Geothermal Resources, International Symposium on Geothermal Energy (Geothermal Research Society of Japan, Tokyo, Japan, 1988), pp. 526-529.

M. Smith, and G. Ponder, editors, "Hot Dry Rock Geothermal Energy Development Program Annual Report, Fisca1 Year 1981," Los Alamos National Laboratory report LA-9287-HDR (April 1982).

A. Streckeisen, chairman, "Plutonic rocks. Classsification and nomenclature recommended by the IUGS Subcommission on the Systematics of Igneous Rocks," Geotimes 18, 26-30, (1973).

F. West and A. Laughlin, "Spectral Gamma Logging in Crystalline Basement Rocks," Geology 4, 617-618.

H. Williams, F. Turner, and C. Gilbert, Petrography (W.H. Freeman and Company, San Francisco, 1954), $406 \mathrm{pp}$.

I. Zabavnikova, "Diadochic Substitutions in Sphene,” Geochemistry 3, 271-278 (1957). 


\section{APPENDIX A}

\section{ELECTRON MICROPROBE ANALYSES OF MINERALS}

Microprobe analyses are grouped first by mineral, in the order plagioclase and alkali feldspar, biotite, hornblende and other amphibole, clinopyroxene, garnet, tourmaline, and sphene. This order corresponds approximately to decreasing order of abundance in the Precambrian rocks. Within each mineral group, the analyses are arranged according to the rock type in which the minerals occur; the order is granodiorite, monzogranite, leucogranite, tonalite, amphibolite, and biotite-plagioclase rock. There is a further ordering of analyses for each rock type by drill hole, in the order EE-2, EE-2A, and EE-3A, and by increasing depth within each drill hole.

The notation "n.a." indicates that an analysis did not include the element oxide for which the notation appears. The notation "n.d." signifies that an element oxide is present in an amount below the detection limit. 


\begin{tabular}{|c|c|c|c|c|}
\hline \multicolumn{5}{|c|}{ EE-3A 11600-2 plagioclase (granodiorite, core 3) } \\
\hline & D-1 & D-2 & D-3 & $\mathrm{X}-1$ \\
\hline \multicolumn{5}{|c|}{ Weight percent } \\
\hline $\mathrm{SiO}_{2}$ & 60.2 & 60.5 & 60.7 & 59.6 \\
\hline $\mathrm{TiO}_{2}$ & n.d. & n.d. & n.d. & n.d. \\
\hline $\mathrm{Al}_{2} \mathrm{O}_{3}$ & 25.2 & 25.1 & 25.0 & 25.3 \\
\hline $\mathrm{FeO}$ & 0.14 & 0.13 & 0.12 & 0.05 \\
\hline $\mathrm{MgO}$ & n.d. & n.d. & n.d. & n.d. \\
\hline $\mathrm{BaO}$ & 0.14 & 0.11 & 0.11 & n.d. \\
\hline $\mathrm{CaO}$ & 6.1 & 6.1 & 6.1 & 6.3 \\
\hline $\mathrm{Na}_{2} \mathrm{O}$ & 8.3 & 8.4 & 8.6 & 8.3 \\
\hline $\mathrm{K}_{2} \mathrm{O}$ & 0.09 & 0.14 & 0.13 & 0.10 \\
\hline Total & 100.2 & 100.5 & 100.8 & 99.7 \\
\hline \multicolumn{5}{|c|}{ Stoichiometry based on 8 oxygens } \\
\hline $\mathrm{Si}$ & 2.677 & 2.683 & 2.689 & 2.667 \\
\hline $\mathrm{Ti}$ & 0.000 & 0.000 & 0.000 & 0.000 \\
\hline $\mathrm{Al}$ & 1.324 & 1.314 & 1.303 & 1.334 \\
\hline $\mathrm{Fe}$ & 0.005 & 0.005 & 0.005 & 0.002 \\
\hline $\mathrm{Mg}$ & 0.000 & 0.000 & 0.000 & 0.000 \\
\hline $\mathrm{Ba}$ & 0.002 & 0.002 & 0.002 & 0.000 \\
\hline $\mathrm{Ca}$ & 0.289 & 0.288 & 0.290 & 0.301 \\
\hline $\mathrm{Na}$ & 0.720 & 0.724 & 0.734 & 0.718 \\
\hline K & 0.005 & 0.008 & 0.007 & 0.006 \\
\hline \multicolumn{5}{|c|}{ End-member proportions } \\
\hline $\mathrm{Ab}$ & 70.8 & 70.8 & 71.0 & 70.0 \\
\hline $\mathrm{An}$ & 28.4 & 28.2 & 28.0 & 29.4 \\
\hline Or & 0.5 & 0.8 & 0.8 & 0.6 \\
\hline $\mathrm{Cn}$ & 0.3 & 0.2 & 0.2 & 0.0 \\
\hline
\end{tabular}




\begin{tabular}{|c|c|c|c|c|c|c|c|}
\hline \multicolumn{8}{|c|}{ EE-2 12849-3 plagioclase (monzogranite, core 2) } \\
\hline & \multicolumn{3}{|c|}{ Phenocryst, core to rim } & \multicolumn{2}{|c|}{ matrix } & \multirow{2}{*}{$\begin{array}{c}\text { phenocryst } \\
\text { A-7 } \\
\end{array}$} & \multirow{2}{*}{$\frac{\text { matrix }}{\mathrm{X}-4}$} \\
\hline & A-2 & A-3 & A-4 & A-5 & A-6 & & \\
\hline \multicolumn{8}{|c|}{ Weight percent } \\
\hline $\mathrm{SiO}_{2}$ & 55.4 & 60.3 & 61.8 & 60.1 & 61.4 & 54.4 & 60.5 \\
\hline $\mathrm{TiO}_{2}$ & 0.00 & 0.00 & 0.00 & 0.00 & 0.00 & 0.00 & 0.00 \\
\hline $\mathrm{Al}_{2} \mathrm{O}_{3}$ & 29.3 & 25.8 & 24.6 & 25.7 & 24.4 & 28.9 & 24.5 \\
\hline $\mathrm{FeO}$ & n.d. & 0.08 & 0.13 & 0.00 & 0.05 & 0.29 & 0.00 \\
\hline $\mathrm{MgO}$ & 0.00 & 0.00 & 0.00 & 0.00 & 0.00 & 0.00 & 0.00 \\
\hline $\mathrm{BaO}$ & 0.00 & 0.00 & n.d. & 0.00 & 0.00 & 0.00 & 0.00 \\
\hline $\mathrm{CaO}$ & 10.8 & 6.7 & 5.3 & 6.6 & 5.7 & 11.1 & 5.0 \\
\hline $\mathrm{Na}_{2} \mathrm{O}$ & 4.6 & 6.6 & 8.7 & 8.3 & 8.8 & 5.7 & 9.5 \\
\hline $\mathrm{K}_{2} \mathrm{O}$ & 0.09 & 0.13 & 0.18 & 0.12 & 0.14 & 0.09 & 0.00 \\
\hline Total & 100.2 & 99.6 & 100.7 & 100.8 & 100.5 & 100.5 & 99.5 \\
\hline \multicolumn{8}{|c|}{ Stoichiometry based on 8 oxygens } \\
\hline $\mathrm{Si}$ & 2.479 & 2.681 & 2.723 & 2.657 & 2.719 & 2.450 & 2.853 \\
\hline $\mathrm{Ti}$ & 0.000 & 0.000 & 0.000 & 0.000 & 0.000 & 0.000 & 0.000 \\
\hline $\mathrm{Al}$ & 1.547 & 1.351 & 1.280 & 1.342 & 1.274 & 1.536 & 1.362 \\
\hline $\mathrm{Fe}$ & 0.000 & 0.003 & 0.005 & 0.000 & 0.002 & 0.011 & 0.000 \\
\hline $\mathrm{Mg}$ & 0.000 & 0.000 & 0.000 & 0.000 & 0.000 & 0.000 & 0.000 \\
\hline $\mathrm{Ba}$ & 0.000 & 0.000 & 0.000 & 0.000 & 0.000 & 0.000 & 0.000 \\
\hline $\mathrm{Ca}$ & 0.519 & 0.321 & 0.251 & 0.313 & 0.268 & 0.533 & 0.250 \\
\hline $\mathrm{Na}$ & 0.396 & 0.564 & 0.746 & 0.714 & 0.755 & 0.499 & 0.870 \\
\hline $\mathrm{K}$ & 0.005 & 0.008 & 0.010 & 0.007 & 0.008 & 0.005 & 0.000 \\
\hline \multicolumn{8}{|c|}{ End-member proportions } \\
\hline $\mathrm{Ab}$ & 43.0 & 63.2 & 74.0 & 69.1 & 73.2 & 48.1 & 77.7 \\
\hline An & 56.4 & 36.0 & 25.0 & 30.3 & 26.0 & 51.4 & 22.3 \\
\hline Or & 0.6 & 0.8 & 1.0 & 0.6 & 0.8 & 0.5 & 0.0 \\
\hline $\mathrm{Cn}$ & 0.0 & 0.0 & 0.0 & 0.0 & 0.0 & 0.0 & 0.0 \\
\hline
\end{tabular}




\begin{tabular}{|c|c|c|c|c|c|}
\hline \multicolumn{6}{|c|}{ EE-2 12853-2 plagioclase (monzogranite, core 2) } \\
\hline & \multicolumn{5}{|c|}{ 1-mm phenocryst } \\
\hline & core & & & & rim \\
\hline & A-1 & A-2 & A-3 & A-4 & A-5 \\
\hline \multicolumn{6}{|c|}{ Weight percent } \\
\hline $\mathrm{SiO}_{2}$ & 60.8 & 60.9 & 60.8 & 62.0 & 61.0 \\
\hline $\mathrm{TiO}_{2}$ & 0.00 & n.d. & n.d. & 0.09 & n.d. \\
\hline $\mathrm{Al}_{2} \mathrm{O}_{3}$ & 24.8 & 24.2 & 24.4 & 23.7 & 23.8 \\
\hline $\mathrm{FeO}$ & n.d. & n.d. & 0.07 & 0.07 & 0.11 \\
\hline $\mathrm{MgO}$ & 0.00 & 0.00 & 0.00 & 0.00 & 0.00 \\
\hline $\mathrm{BaO}$ & n.d. & n.d. & 0.19 & n.d. & n.d. \\
\hline $\mathrm{CaO}$ & 6.22 & 5.62 & 6.03 & 4.86 & 5.72 \\
\hline $\mathrm{Na}_{2} \mathrm{O}$ & 7.1 & 8.5 & 8.0 & 8.9 & 8.2 \\
\hline $\mathrm{K}_{2} \mathrm{O}$ & 0.15 & 0.10 & 0.20 & 0.15 & 0.15 \\
\hline Total & 99.1 & 99.3 & 99.7 & 99.8 & 99.0 \\
\hline \multicolumn{6}{|c|}{ Stoichiometry based on 8 oxygens } \\
\hline $\mathrm{Si}$ & 2.715 & 2.721 & 2.713 & 2.754 & 2.734 \\
\hline $\mathrm{Ti}$ & 0.000 & 0.000 & 0.000 & 0.003 & 0.000 \\
\hline $\mathrm{Al}$ & 1.303 & 1.274 & 1.285 & 1.243 & 1.259 \\
\hline $\mathrm{Fe}$ & 0.000 & 0.000 & 0.003 & 0.003 & 0.004 \\
\hline $\mathrm{Mg}$ & 0.000 & 0.000 & 0.000 & 0.000 & 0.000 \\
\hline $\mathrm{Ba}$ & 0.000 & 0.000 & 0.003 & 0.000 & 0.000 \\
\hline $\mathrm{Ca}$ & 0.298 & 0.269 & 0.288 & 0.231 & 0.275 \\
\hline $\mathrm{Na}$ & 0.618 & 0.734 & 0.688 & 0.763 & 0.715 \\
\hline K & 0.008 & 0.006 & 0.011 & 0.009 & 0.009 \\
\hline \multicolumn{6}{|c|}{ End-member proportions } \\
\hline $\mathrm{Ab}$ & 66.9 & 72.8 & 69.5 & 76.1 & 71.6 \\
\hline An & 32.2 & 26.7 & 29.1 & 23.1 & 27.5 \\
\hline Or & 0.9 & 0.5 & 1.1 & 0.8 & 0.9 \\
\hline $\mathrm{Cn}$ & 0.0 & 0.0 & 0.3 & 0.0 & 0.0 \\
\hline
\end{tabular}




\begin{tabular}{|c|c|c|c|c|c|c|c|}
\hline \multicolumn{8}{|c|}{ EE-3A 11615-8A plagioclase (biotite monzogranite, core 3) } \\
\hline & A-1 & A-2 & A-3 & A-4 & A-5 & A-6 & A-7 \\
\hline \multicolumn{8}{|c|}{ Weight percent } \\
\hline $\mathrm{SiO}_{2}$ & 63.3 & 60.0 & 61.1 & 62.5 & 58.8 & 62.0 & 62.1 \\
\hline $\mathrm{TiO}_{2}$ & 0.00 & 0.00 & 0.04 & 0.00 & 0.00 & n.d. & 0.00 \\
\hline $\mathrm{Al}_{2} \mathrm{O}_{3}$ & 22.7 & 25.2 & 24.2 & 23.0 & 25.3 & 23.5 & 23.6 \\
\hline $\mathrm{FeO}$ & 0.11 & 0.05 & 0.08 & 0.08 & 0.07 & 0.07 & 0.12 \\
\hline $\mathrm{MgO}$ & 0.00 & 0.00 & 0.00 & 0.00 & 0.00 & 0.00 & 0.00 \\
\hline $\mathrm{BaO}$ & 0.00 & 0.06 & 0.00 & 0.00 & 0.11 & 0.00 & 0.00 \\
\hline $\mathrm{CaO}$ & 4.09 & 6.7 & 5.38 & 4.00 & 7.0 & 4.88 & 4.80 \\
\hline $\mathrm{Na}_{2} \mathrm{O}$ & 10.3 & 8.4 & 9.4 & 10.1 & 8.4 & 9.8 & 9.8 \\
\hline $\mathrm{K}_{2} \mathrm{O}$ & 0.18 & 0.13 & 0.16 & 0.12 & 0.14 & 0.11 & 0.21 \\
\hline Total & 100.7 & 100.5 & 100.4 & 99.8 & 99.8 & 100.4 & 100.6 \\
\hline \multicolumn{8}{|c|}{ Stoichiometry based on 8 oxygens } \\
\hline $\mathrm{Si}$ & 2.795 & 2.665 & 2.713 & 2.781 & 2.641 & 2.748 & 2.749 \\
\hline $\mathrm{Ti}$ & 0.000 & 0.000 & 0.001 & 0.000 & 0.000 & 0.000 & 0.000 \\
\hline $\mathrm{Al}$ & 1.178 & 1.321 & 1.269 & 1.204 & 1.338 & 1.229 & 1.230 \\
\hline $\mathrm{Fe}$ & 0.004 & 0.002 & 0.003 & 0.003 & 0.002 & 0.003 & 0.005 \\
\hline $\mathrm{Mg}$ & 0.000 & 0.000 & 0.000 & 0.000 & 0.000 & 0.000 & 0.000 \\
\hline $\mathrm{Ba}$ & 0.000 & 0.001 & 0.000 & 0.000 & 0.002 & 0.000 & 0.000 \\
\hline $\mathrm{Ca}$ & 0.193 & 0.319 & 0.256 & 0.191 & 0.336 & 0.232 & 0.228 \\
\hline $\mathrm{Na}$ & 0.880 & 0.725 & 0.808 & 0.868 & 0.735 & 0.844 & 0.837 \\
\hline K & 0.010 & 0.007 & 0.009 & 0.007 & 0.008 & 0.006 & 0.012 \\
\hline \multicolumn{8}{|c|}{ End-member proportions } \\
\hline $\mathrm{Ab}$ & 81.1 & 68.9 & 75.2 & 81.4 & 67.9 & 78.0 & 77.7 \\
\hline An & 17.9 & 30.3 & 23.9 & 17.9 & 31.1 & 21.4 & 21.2 \\
\hline Or & 1.0 & 0.7 & 0.9 & 0.7 & 0.8 & 0.6 & 1.1 \\
\hline $\mathrm{Cn}$ & 0.0 & 0.1 & 0.0 & 0.0 & 0.2 & 0.0 & 0.0 \\
\hline
\end{tabular}




\begin{tabular}{|c|c|c|c|c|c|c|c|}
\hline \multicolumn{8}{|c|}{ EE-3A 11615-8B plagioclase (biotite monzogranite and leucogranite, core 3) } \\
\hline & \multicolumn{3}{|c|}{ biotite monzogranite } & \multicolumn{4}{|c|}{ leucogranite } \\
\hline & $\mathbf{X - 3}$ & $\mathrm{X}-4$ & $\mathrm{X}-5$ & $\mathrm{X}-1$ & $\mathrm{X}-2$ & $\mathrm{X}-6$ & $\mathrm{X}-7$ \\
\hline \multicolumn{8}{|c|}{ Weight percent } \\
\hline $\mathrm{SiO}_{2}$ & 63.9 & 62.8 & 62.9 & 64.1 & 63.2 & 62.9 & 63.5 \\
\hline $\mathrm{TiO}_{2}$ & 0.00 & 0.00 & 0.00 & 0.00 & 0.00 & 0.00 & 0.00 \\
\hline $\mathrm{Al}_{2} \mathrm{O}_{3}$ & 23.2 & 23.8 & 23.7 & 22.9 & 23.6 & 23.6 & 23.1 \\
\hline $\mathrm{FeO}$ & 0.00 & 0.10 & 0.09 & 0.06 & n.d. & 0.06 & 0.08 \\
\hline $\mathrm{MgO}$ & 0.00 & 0.00 & 0.00 & 0.00 & 0.00 & 0.00 & n.d. \\
\hline $\mathrm{BaO}$ & n.d. & 0.00 & n.d. & 0.00 & 0.00 & 0.00 & 0.00 \\
\hline $\mathrm{CaO}$ & 3.62 & 4.16 & 4.14 & 2.54 & 4.02 & 4.36 & 3.68 \\
\hline $\mathrm{Na}_{2} \mathrm{O}$ & 9.2 & 9.3 & 9.4 & 9.7 & 8.9 & 9.1 & 9.8 \\
\hline $\mathrm{K}_{2} \mathrm{O}$ & 0.10 & 0.18 & 0.18 & 0.53 & 0.20 & 0.17 & 0.31 \\
\hline Total & 100.0 & 100.3 & 100.4 & 99.8 & 99.9 & 100.2 & 100.5 \\
\hline \multicolumn{8}{|c|}{ Stoichiometry based on 8 oxygens } \\
\hline $\mathrm{Si}$ & 2.812 & 2.770 & 2.774 & 2.831 & 2.791 & 2.778 & 2.798 \\
\hline $\mathrm{Ti}$ & 0.000 & 0.000 & 0.000 & 0.000 & 0.000 & 0.000 & 0.000 \\
\hline $\mathrm{Al}$ & 1.205 & 1.238 & 1.231 & 1.191 & 1.228 & 1.227 & 1.198 \\
\hline $\mathrm{Fe}$ & 0.000 & 0.004 & 0.003 & 0.002 & 0.000 & 0.002 & 0.003 \\
\hline $\mathrm{Mg}$ & 0.000 & 0.000 & 0.000 & 0.000 & 0.000 & 0.000 & 0.000 \\
\hline $\mathrm{Ba}$ & 0.000 & 0.000 & 0.000 & 0.000 & 0.000 & 0.000 & 0.000 \\
\hline $\mathrm{Ca}$ & 0.171 & 0.197 & 0.196 & 0.120 & 0.190 & 0.206 & 0.174 \\
\hline $\mathrm{Na}$ & 0.785 & 0.794 & 0.802 & 0.829 & 0.758 & 0.780 & 0.839 \\
\hline $\mathrm{K}$ & 0.005 & 0.010 & 0.010 & 0.030 & 0.011 & 0.010 & 0.018 \\
\hline \multicolumn{8}{|c|}{ End-member proportions } \\
\hline $\mathrm{Ab}$ & 81.6 & 79.3 & 79.6 & 84.7 & 79.0 & 78.3 & 81.4 \\
\hline An & 17.8 & 19.7 & 19.4 & 12.3 & 19.8 & 20.7 & 16.9 \\
\hline Or & 0.6 & 1.0 & 1.0 & 3.0 & 1.2 & 1.0 & 1.7 \\
\hline $\mathrm{Cn}$ & 0.0 & 0.0 & 0.0 & 0.0 & 0.0 & 0.0 & 0.0 \\
\hline
\end{tabular}




\begin{tabular}{|c|c|c|c|c|c|c|c|}
\hline \multicolumn{4}{|c|}{$\begin{array}{l}\text { EE-2A 12025-30A plagioclase } \\
\text { (leucogranite, bit cutting) }\end{array}$} & \multicolumn{4}{|c|}{$\begin{array}{l}\text { EE-3A 9450-5C-B plagioclase } \\
\text { (leucogranite dike in amphibolite, core } 1 \text { ) }\end{array}$} \\
\hline & A-4 & A-5 & A-6 & A-13 & A-14 & $X-1$ & $X-2$ \\
\hline \multicolumn{8}{|c|}{ Weight percent } \\
\hline $\mathrm{SiO}_{2}$ & 65.5 & 64.4 & 65.3 & 60.3 & 60.6 & 60.0 & 61.4 \\
\hline $\mathrm{TiO}_{2}$ & 0.00 & 0.06 & 0.11 & 0.00 & 0.03 & 0.00 & 0.00 \\
\hline $\mathrm{Al}_{2} \mathrm{O}_{3}$ & 21.6 & 23.4 & 22.2 & 25.5 & 25.0 & 25.1 & 24.4 \\
\hline $\mathrm{FeO}$ & 0.00 & n.d. & 0.00 & 0.09 & 0.09 & 0.14 & 0.04 \\
\hline $\mathrm{MgO}$ & 0.00 & 0.00 & 0.00 & 0.00 & 0.00 & 0.00 & 0.00 \\
\hline $\mathrm{BaO}$ & 0.16 & 0.14 & 0.32 & 0.00 & 0.00 & 0.00 & 0.00 \\
\hline $\mathrm{CaO}$ & 1.92 & 2.48 & 2.22 & 6.0 & 5.5 & 5.9 & 4.6 \\
\hline $\mathrm{Na}_{2} \mathrm{O}$ & 10.4 & 10.2 & 10.6 & 7.9 & 8.4 & 8.0 & 8.6 \\
\hline $\mathrm{K}_{2} \mathrm{O}$ & 0.06 & 0.09 & 0.12 & 0.11 & 0.09 & 0.09 & 0.12 \\
\hline Total & 99.6 & 100.8 & 100.9 & 99.9 & 99.7 & 99.2 & 99.2 \\
\hline \multicolumn{8}{|c|}{ Stoichiometry based on 8 oxygens } \\
\hline $\mathrm{Si}$ & 2.888 & 2.815 & 2.857 & 2.681 & 2.699 & 2.688 & 2.739 \\
\hline $\mathrm{Ti}$ & 0.000 & 0.002 & 0.003 & 0.000 & 0.001 & 0.000 & 0.000 \\
\hline $\mathrm{Al}$ & 1.122 & 1.208 & 1.143 & 1.335 & 1.314 & 1.324 & 1.281 \\
\hline $\mathrm{Fe}$ & 0.000 & 0.000 & 0.000 & 0.003 & 0.003 & 0.005 & 0.001 \\
\hline $\mathrm{Mg}$ & 0.000 & 0.000 & 0.000 & 0.000 & 0.000 & 0.000 & 0.000 \\
\hline $\mathrm{Ba}$ & 0.003 & 0.002 & 0.005 & 0.000 & 0.000 & 0.000 & 0.000 \\
\hline $\mathrm{Ca}$ & 0.091 & 0.116 & 0.104 & 0.286 & 0.261 & 0.284 & 0.221 \\
\hline $\mathrm{Na}$ & 0.890 & 0.868 & 0.902 & 0.684 & 0.725 & 0.694 & 0.746 \\
\hline K & 0.003 & 0.005 & 0.007 & 0.006 & 0.005 & 0.005 & 0.007 \\
\hline \multicolumn{8}{|c|}{ End-member proportions } \\
\hline $\mathrm{Ab}$ & 90.2 & 87.6 & 88.6 & 70.1 & 73.1 & 70.6 & 76.6 \\
\hline An & 9.2 & 11.7 & 10.2 & 29.3 & 26.4 & 28.9 & 22.7 \\
\hline Or & 0.3 & 0.5 & 0.7 & 0.6 & 0.5 & 0.5 & 0.7 \\
\hline $\mathrm{Cn}$ & 0.3 & 0.2 & 0.5 & $0, .0$ & 0.0 & 0.0 & 0.0 \\
\hline
\end{tabular}




\begin{tabular}{|c|c|c|c|c|c|c|c|}
\hline \multicolumn{8}{|c|}{ EE-3A 10877.8 plagioclase (leucogranite, core 2) } \\
\hline & \multicolumn{3}{|c|}{ primary crystals } & \multicolumn{2}{|c|}{ composite crystal } & \multicolumn{2}{|c|}{ composite crystal } \\
\hline & & & & \multirow{2}{*}{$\frac{\text { primary }}{\text { B1A-4 }}$} & \multirow{2}{*}{$\begin{array}{c}\text { overgrowth } \\
\text { B1A-3 } \\
\end{array}$} & \multirow{2}{*}{$\begin{array}{c}\text { primary } \\
\text { B1A-9 }\end{array}$} & \multirow{2}{*}{$\begin{array}{c}\text { overgrowth } \\
\text { B1A-8 }\end{array}$} \\
\hline & A1-3 & A1-7 & A2-6 & & & & \\
\hline \multicolumn{8}{|c|}{ Weight percent } \\
\hline $\mathrm{SiO}_{2}$ & 64.9 & 65.3 & 64.8 & 67.0 & 67.6 & 67.9 & 68.4 \\
\hline $\mathrm{TiO}_{2}$ & 0.00 & 0.00 & 0.00 & 0.00 & 0.00 & 0.02 & 0.02 \\
\hline $\mathrm{Al}_{2} \mathrm{O}_{3}$ & 21.0 & 21.1 & 21.6 & 20.0 & 20.4 & 20.1 & 19.9 \\
\hline $\mathrm{FeO}$ & n.d. & 0.05 & n.d. & 0.00 & 0.00 & 0.00 & 0.00 \\
\hline $\mathrm{MgO}$ & 0.00 & 0.00 & 0.00 & 0.00 & 0.00 & 0.00 & 0.00 \\
\hline $\mathrm{BaO}$ & 0.00 & 0.00 & 0.00 & 0.05 & 0.00 & 0.13 & n.d. \\
\hline $\mathrm{CaO}$ & 2.53 & 2.45 & 2.35 & 0.62 & 0.95 & 0.60 & 0.27 \\
\hline $\mathrm{Na}_{2} \mathrm{O}$ & 10.7 & 10.8 & 10.8 & 11.5 & 11.4 & 11.4 & 11.7 \\
\hline $\mathrm{K}_{2} \mathrm{O}$ & 0.12 & 0.13 & 0.10 & 0.04 & 0.07 & 0.09 & 0.09 \\
\hline Total & 99.3 & 99.8 & 99.7 & 99.2 & 100.4 & 100.2 & 100.4 \\
\hline \multicolumn{8}{|c|}{ Stoichiometry based on 8 oxygens } \\
\hline $\mathrm{Si}$ & 2.884 & 2.884 & 2.868 & 2.959 & 2.949 & 2.965 & 2.980 \\
\hline $\mathrm{Ti}$ & 0.000 & 0.000 & 0.000 & 0.000 & 0.000 & 0.001 & 0.001 \\
\hline $\mathrm{Al}$ & 1.098 & 1.100 & 1.124 & 1.039 & 1.049 & 1.035 & 1.020 \\
\hline $\mathrm{Fe}$ & 0.000 & 0.002 & 0.000 & 0.000 & 0.000 & 0.000 & 0.000 \\
\hline $\mathrm{Mg}$ & 0.000 & 0.000 & 0.000 & 0.000 & 0.000 & 0.000 & 0.000 \\
\hline $\mathrm{Ba}$ & 0.000 & 0.000 & 0.000 & 0.001 & 0.000 & 0.002 & 0.000 \\
\hline $\mathrm{Ca}$ & 0.120 & 0.116 & 0.111 & 0.029 & 0.045 & 0.028 & 0.013 \\
\hline $\mathrm{Na}$ & 0.923 & 0.922 & 0.927 & 0.983 & 0.964 & 0.964 & 0.984 \\
\hline $\mathrm{K}$ & 0.007 & 0.007 & 0.005 & 0.002 & 0.004 & 0.005 & 0.005 \\
\hline \multicolumn{8}{|c|}{ End-member proportions } \\
\hline $\mathrm{Ab}$ & 87.9 & 88.2 & 88.8 & 96.8 & 95.2 & 96.5 & 98.3 \\
\hline An & 11.5 & 11.1 & 10.7 & 2.9 & 4.4 & 2.8 & 1.2 \\
\hline Or & 0.6 & 0.7 & 0.5 & 0.2 & 0.4 & 0.5 & 0.5 \\
\hline $\mathrm{Cn}$ & 0.0 & 0.0 & 0.0 & 0.1 & 0.0 & 0.2 & 0.0 \\
\hline
\end{tabular}




\begin{tabular}{|c|c|c|c|c|c|}
\hline \multicolumn{6}{|c|}{ EE-3A 10877.8 plagioclase (leucogranite, core 2 ) continued } \\
\hline & \multicolumn{5}{|c|}{ primary crystal, associated fracture filling, and overgrowth } \\
\hline & \multicolumn{2}{|c|}{ primary } & \multicolumn{2}{|c|}{ fracture filling } & \multirow{2}{*}{$\begin{array}{c}\text { overgrowth } \\
\text { F-2 }\end{array}$} \\
\hline & F-3 & F-4 & F-1 & F-5 & \\
\hline \multicolumn{6}{|c|}{ Weight percent } \\
\hline $\mathrm{SiO}_{2}$ & 68.5 & 67.9 & 68.8 & 69.1 & 68.7 \\
\hline $\mathrm{TiO}_{2}$ & 0.00 & 0.00 & 0.07 & 0.00 & 0.00 \\
\hline $\mathrm{Al}_{2} \mathrm{O}_{3}$ & 20.4 & 20.6 & 19.9 & 19.6 & 20.0 \\
\hline $\mathrm{FeO}$ & n.d. & n.d. & 0.07 & 0.00 & 0.00 \\
\hline $\mathrm{MgO}$ & 0.00 & n.d. & n.d. & 0.00 & n.d. \\
\hline $\mathrm{BaO}$ & 0.00 & 0.00 & 0.00 & 0.00 & 0.00 \\
\hline $\mathrm{CaO}$ & 0.20 & 1.10 & 0.07 & 0.03 & 0.62 \\
\hline $\mathrm{Na}_{2} \mathrm{O}$ & 11.3 & 11.1 & 11.7 & 11.8 & 11.1 \\
\hline $\mathrm{K}_{2} \mathrm{O}$ & 0.35 & 0.07 & 0.00 & 0.04 & 0.07 \\
\hline Total & 100.8 & 100.8 & 100.6 & 100.6 & 100.5 \\
\hline \multicolumn{6}{|c|}{ Stoichiometry based on 8 oxygens } \\
\hline $\mathrm{Si}$ & 2.971 & 2.948 & 2.985 & 2.998 & 2.982 \\
\hline $\mathrm{Ti}$ & 0.000 & 0.000 & 0.002 & 0.000 & 0.000 \\
\hline $\mathrm{Al}$ & 1.043 & 1.055 & 1.019 & 1.003 & 1.024 \\
\hline $\mathrm{Fe}$ & 0.000 & 0.000 & 0.002 & 0.000 & 0.000 \\
\hline $\mathrm{Mg}$ & 0.000 & 0.000 & 0.000 & 0.000 & 0.000 \\
\hline $\mathrm{Ba}$ & 0.000 & 0.000 & 0.000 & 0.000 & 0.000 \\
\hline $\mathrm{Ca}$ & 0.009 & 0.051 & 0.003 & 0.001 & 0.029 \\
\hline $\mathrm{Na}$ & 0.947 & 0.933 & 0.980 & 0.993 & 0.935 \\
\hline $\mathrm{K}$ & 0.019 & 0.004 & 0.000 & 0.002 & 0.004 \\
\hline \multicolumn{6}{|c|}{ End-member proportions } \\
\hline $\mathrm{Ab}$ & 97.1 & 94.4 & 99.7 & 99.6 & 96.6 \\
\hline An & 0.9 & 5.2 & 0.3 & 0.2 & 3.0 \\
\hline Or & 2.0 & 0.4 & 0.0 & 0.2 & 0.4 \\
\hline $\mathrm{Cn}$ & 0.0 & 0.0 & 0.0 & 0.0 & 0.0 \\
\hline
\end{tabular}




\begin{tabular}{|c|c|c|c|c|c|c|}
\hline \multicolumn{7}{|c|}{ EE-3A 10877.8 plagioclase (leucogranite, core 2 ) continued } \\
\hline & \multicolumn{6}{|c|}{ primary crystal and associated fracture fillings } \\
\hline & \multicolumn{2}{|c|}{ primary } & \multicolumn{2}{|c|}{ older filling } & \multicolumn{2}{|c|}{ younger filling } \\
\hline & C1-5 & C1-6 & C1-3 & C1-4 & C1-1 & $\mathrm{Cl}-2$ \\
\hline \multicolumn{7}{|c|}{ Weight percent } \\
\hline $\mathrm{SiO}_{2}$ & 68.7 & 68.1 & 68.6 & 68.7 & 68.7 & 68.8 \\
\hline $\mathrm{TiO}_{2}$ & 0.06 & 0.00 & 0.00 & 0.00 & 0.04 & 0.00 \\
\hline $\mathrm{Al}_{2} \mathrm{O}_{3}$ & 20.0 & 20.5 & 19.4 & 19.5 & 19.5 & 19.7 \\
\hline $\mathrm{FeO}$ & n.d. & 0.05 & n.d. & 0.07 & 0.19 & 0.14 \\
\hline $\mathrm{MgO}$ & n.d. & 0.00 & 0.00 & 0.00 & 0.00 & 0.00 \\
\hline $\mathrm{BaO}$ & 0.00 & 0.06 & 0.00 & n.d. & 0.00 & 0.00 \\
\hline $\mathrm{CaO}$ & 0.21 & 0.76 & 0.05 & 0.06 & 0.04 & 0.04 \\
\hline $\mathrm{Na}_{2} \mathrm{O}$ & 11.3 & 11.1 & 11.7 & 11.8 & 12.0 & 11.6 \\
\hline $\mathrm{K}_{2} \mathrm{O}$ & 0.04 & 0.05 & n.d. & 0.05 & 0.04 & n.d. \\
\hline Total & 100.3 & 100.6 & 99.8 & 100.2 & 100.5 & 100.3 \\
\hline \multicolumn{7}{|c|}{ Stoichiometry based on 8 oxygens } \\
\hline $\mathrm{Si}$ & 2.986 & 2.958 & 2.998 & 2.995 & 2.989 & 2.994 \\
\hline $\mathrm{Ti}$ & 0.002 & 0.000 & 0.000 & 0.000 & 0.001 & 0.000 \\
\hline Al & 1.024 & 1.049 & 1.001 & 1.003 & 1.001 & 1.010 \\
\hline $\mathrm{Fe}$ & 0.000 & 0.002 & 0.000 & 0.003 & 0.007 & 0.005 \\
\hline $\mathrm{Mg}$ & 0.000 & 0.000 & 0.000 & 0.000 & 0.000 & 0.000 \\
\hline $\mathrm{Ba}$ & 0.000 & 0.001 & 0.000 & 0.000 & 0.000 & 0.000 \\
\hline $\mathrm{Ca}$ & 0.010 & 0.036 & 0.002 & 0.003 & 0.002 & 0.002 \\
\hline $\mathrm{Na}$ & 0.954 & 0.938 & 0.995 & 0.996 & 1.013 & 0.978 \\
\hline $\mathrm{K}$ & 0.002 & 0.003 & 0.000 & 0.003 & 0.002 & 0.001 \\
\hline \multicolumn{7}{|c|}{ End-member proportions } \\
\hline $\mathrm{Ab}$ & 98.8 & 96.0 & 99.8 & 99.4 & 99.6 & 99.7 \\
\hline An & 1.0 & 3.6 & 0.2 & 0.3 & 0.2 & 0.2 \\
\hline Or & 0.2 & 0.3 & 0.0 & 0.3 & 0.2 & 0.1 \\
\hline $\mathrm{Cn}$ & 0.0 & 0.1 & 0.0 & 0.0 & 0.0 & 0.0 \\
\hline
\end{tabular}




\begin{tabular}{|c|c|c|c|c|c|}
\hline \multicolumn{6}{|c|}{ EE-3A 10877.8 and $10877.8 b$ plagioclase (leucogranite, core 2 ) continued } \\
\hline & \multicolumn{5}{|c|}{ euhedral fracture-filling crystals } \\
\hline & \multicolumn{3}{|c|}{ pitted crystals } & \multicolumn{2}{|c|}{ clear crystals } \\
\hline & B2-4 & B2-5 & B2-6 & B2-3 & A-3 \\
\hline \multicolumn{6}{|c|}{ Weight percent } \\
\hline $\mathrm{SiO}_{2}$ & 69.7 & 67.9 & 68.8 & 68.1 & 68.6 \\
\hline $\mathrm{TiO}_{2}$ & 0.00 & 0.00 & 0.00 & 0.00 & 0.00 \\
\hline $\mathrm{Al}_{2} \mathrm{O}_{3}$ & 20.0 & 20.0 & 19.9 & 19.7 & 19.9 \\
\hline $\mathrm{FeO}$ & 0.20 & 0.33 & 0.08 & 0.67 & 0.16 \\
\hline $\mathrm{MgO}$ & 0.00 & 0.00 & 0.00 & 0.00 & 0.00 \\
\hline $\mathrm{BaO}$ & 0.00 & 0.06 & 0.09 & 0.04 & n.d. \\
\hline $\mathrm{CaO}$ & n.d. & n.d. & 0.04 & 0.03 & 0.08 \\
\hline $\mathrm{Na}_{2} \mathrm{O}$ & 11.0 & 11.9 & 11.9 & 12.1 & 12.1 \\
\hline $\mathrm{K}_{2} \mathrm{O}$ & n.d. & n.d. & n.d. & 0.03 & 0.05 \\
\hline Total & 100.9 & 100.2 & 100.8 & 100.7 & 100.9 \\
\hline \multicolumn{6}{|c|}{ Stoichiometry based on 8 oxygens } \\
\hline $\mathrm{Si}$ & 3.003 & 2.967 & 2.983 & 2.970 & 2.978 \\
\hline $\mathrm{Ti}$ & 0.000 & 0.000 & 0.000 & 0.000 & 0.000 \\
\hline $\mathrm{Al}$ & 1.017 & 1.031 & 1.018 & 1.013 & 1.016 \\
\hline $\mathrm{Fe}$ & 0.007 & 0.012 & 0.003 & 0.024 & 0.006 \\
\hline $\mathrm{Mg}$ & 0.000 & 0.000 & 0.000 & 0.000 & 0.000 \\
\hline $\mathrm{Ba}$ & 0.000 & 0.001 & 0.002 & 0.001 & 0.000 \\
\hline $\mathrm{Ca}$ & 0.000 & 0.000 & 0.002 & 0.001 & 0.004 \\
\hline $\mathrm{Na}$ & 0.920 & 1.009 & 1.000 & 1.026 & 1.016 \\
\hline $\mathrm{K}$ & 0.000 & 0.000 & 0.000 & 0.002 & 0.003 \\
\hline \multicolumn{6}{|c|}{ End-member proportions } \\
\hline $\mathrm{Ab}$ & 100.0 & 99.9 & 99.7 & 99.6 & 99.4 \\
\hline An & 0.0 & 0.0 & 0.2 & 0.1 & 0.4 \\
\hline Or & 0.0 & 0.0 & 0.0 & 0.2 & 0.2 \\
\hline $\mathrm{Cn}$ & 0.0 & 0.1 & 0.1 & 0.1 & 0.0 \\
\hline
\end{tabular}




\begin{tabular}{|c|c|c|c|c|c|c|c|}
\hline \multicolumn{8}{|c|}{ EE-3A 12438-14 plagioclase (tonalite, core 4) } \\
\hline & A1-1 & A1-2 & A1-3 & A1-4 & A1-5 & A1-6 & $\mathrm{X}-1$ \\
\hline \multicolumn{8}{|c|}{ Weight percent } \\
\hline $\mathrm{SiO}_{2}$ & 59.2 & 58.9 & 59.3 & 59.4 & 58.9 & 59.2 & 60.3 \\
\hline $\mathrm{TiO}_{2}$ & 0.00 & 0.00 & 0.00 & 0.00 & 0.03 & 0.00 & 0.00 \\
\hline $\mathrm{Al}_{2} \mathrm{O}_{3}$ & 25.7 & 25.4 & 25.4 & 25.7 & 25.3 & 25.4 & 24.9 \\
\hline $\mathrm{FeO}$ & 0.27 & 0.20 & 0.19 & 0.08 & 0.10 & 0.13 & 0.13 \\
\hline $\mathrm{MgO}$ & 0.00 & 0.00 & 0.00 & 0.00 & 0.00 & 0.00 & 0.00 \\
\hline $\mathrm{BaO}$ & n.d. & 0.00 & 0.00 & 0.00 & 0.00 & 0.00 & 0.00 \\
\hline $\mathrm{CaO}$ & 6.99 & 6.84 & 6.73 & 6.84 & 7.12 & 6.86 & 6.72 \\
\hline $\mathrm{Na}_{2} \mathrm{O}$ & 8.1 & 8.3 & 8.6 & 8.4 & 8.2 & 8.6 & 8.5 \\
\hline $\mathrm{K}_{2} \mathrm{O}$ & 0.13 & 0.16 & 0.14 & 0.11 & 0.10 & 0.07 & 0.14 \\
\hline Total & 100.4 & 99.8 & 100.4 & 100.5 & 99.8 & 100.3 & 100.7 \\
\hline \multicolumn{8}{|c|}{ Stoichiometry based on 8 oxygens } \\
\hline $\mathrm{Si}$ & 2.639 & 2.643 & 2.646 & 2.642 & 2.643 & 2.643 & 2.676 \\
\hline $\mathrm{Ti}$ & 0.000 & 0.000 & 0.000 & 0.000 & 0.001 & 0.000 & 0.000 \\
\hline $\mathrm{Al}$ & 1.349 & 1.341 & 1.337 & 1.348 & 1.337 & 1.337 & 1.303 \\
\hline $\mathrm{Fe}$ & 0.010 & 0.008 & 0.007 & 0.003 & 0.004 & 0.005 & 0.005 \\
\hline $\mathrm{Mg}$ & 0.000 & 0.000 & 0.000 & 0.000 & 0.000 & 0.000 & 0.000 \\
\hline $\mathrm{Ba}$ & 0.000 & 0.000 & 0.000 & 0.000 & 0.000 & 0.000 & 0.000 \\
\hline $\mathrm{Ca}$ & 0.334 & 0.329 & 0.322 & 0.326 & 0.342 & 0.328 & 0.320 \\
\hline $\mathrm{Na}$ & 0.702 & 0.722 & 0.742 & 0.726 & 0.714 & 0.744 & 0.730 \\
\hline $\mathrm{K}$ & 0.007 & 0.009 & 0.008 & 0.006 & 0.006 & 0.004 & 0.008 \\
\hline \multicolumn{8}{|c|}{ End-member proportions } \\
\hline $\mathrm{Ab}$ & 67.3 & 68.1 & 69.3 & 68.6 & 67.2 & 69.1 & 69.0 \\
\hline An & 32.0 & 31.0 & 30.0 & 30.8 & 32.2 & 30.5 & 30.2 \\
\hline Or & 0.7 & 0.9 & 0.7 & 0.6 & 0.6 & 0.4 & 0.8 \\
\hline $\mathrm{Cn}$ & 0.0 & 0.0 & 0.0 & 0.0 & 0.0 & 0.0 & 0.0 \\
\hline
\end{tabular}




\begin{tabular}{|c|c|c|c|c|c|}
\hline \multicolumn{6}{|c|}{ EE-3A 9450-5C-C plagioclase and alkali feldspar (amphibolite, core 1) } \\
\hline & \multicolumn{3}{|c|}{ groundmass } & \multicolumn{2}{|c|}{ fracture filling } \\
\hline & A-5 & A-6 & X-1 & A-1 & A-2 \\
\hline \multicolumn{6}{|c|}{ Weight percent } \\
\hline $\mathrm{SiO}_{2}$ & 59.3 & 59.4 & 59.2 & 63.9 & 64.4 \\
\hline $\mathrm{TiO}_{2}$ & 0.04 & 0.07 & n.d. & 0.00 & 0.00 \\
\hline $\mathrm{Al}_{2} \mathrm{O}_{3}$ & 25.4 & 25.4 & 25.8 & 18.5 & 18.5 \\
\hline $\mathrm{FeO}$ & 0.22 & 0.14 & 0.21 & 0.04 & 0.00 \\
\hline $\mathrm{MgO}$ & 0.00 & 0.00 & 0.00 & 0.03 & n.d. \\
\hline $\mathrm{BaO}$ & n.d. & 0.00 & 0.1 & 0.14 & 0.14 \\
\hline $\mathrm{CaO}$ & 6.6 & 6.4 & 6.7 & 0.17 & 0.07 \\
\hline $\mathrm{Na}_{2} \mathrm{O}$ & 7.9 & 7.8 & 7.8 & 0.06 & 0.11 \\
\hline $\mathrm{K}_{2} \mathrm{O}$ & 0.19 & 0.17 & 0.22 & 16.3 & 16.0 \\
\hline Total & 99.7 & 99.4 & 100.0 & 99.1 & 99.2 \\
\hline \multicolumn{6}{|c|}{ Stoichiometry based on 8 oxygens } \\
\hline $\mathrm{Si}$ & 2.657 & 2.664 & 2.642 & 2.986 & 2.997 \\
\hline $\mathrm{Ti}$ & 0.001 & 0.002 & 0.000 & 0.000 & 0.000 \\
\hline $\mathrm{Al}$ & 1.341 & 1.341 & 1.358 & 1.017 & 1.014 \\
\hline $\mathrm{Fe}$ & 0.008 & 0.005 & 0.008 & 0.001 & 0.000 \\
\hline $\mathrm{Mg}$ & 0.000 & 0.000 & 0.000 & 0.002 & 0.000 \\
\hline $\mathrm{Ba}$ & 0.000 & 0.000 & 0.001 & 0.003 & 0.003 \\
\hline $\mathrm{Ca}$ & 0.314 & 0.307 & 0.322 & 0.009 & 0.003 \\
\hline $\mathrm{Na}$ & 0.688 & 0.679 & 0.679 & 0.006 & 0.010 \\
\hline K & 0.011 & 0.010 & 0.013 & 0.970 & 0.948 \\
\hline \multicolumn{6}{|c|}{ End-member proportions } \\
\hline $\mathrm{Ab}$ & 67.9 & 68.2 & 66.9 & 0.6 & 1.0 \\
\hline An & 31.0 & 30.8 & 31.7 & 0.9 & 0.3 \\
\hline Or & 1.1 & 1.0 & 1.3 & 98.3 & 98.4 \\
\hline $\mathrm{Cn}$ & 0.0 & 0.0 & 0.1 & 0.2 & 0.3 \\
\hline
\end{tabular}




\begin{tabular}{|c|c|c|c|c|c|c|c|}
\hline \multicolumn{8}{|c|}{ EE-3A 12438-51C plagioclase (amphibolite, core 4) } \\
\hline & Plag 1 & Plag 2 & Plag 3 & Plag 4 & Plag 5 & Plag 6 & Plag 8 \\
\hline \multicolumn{8}{|c|}{ Weight percent } \\
\hline $\mathrm{SiO}_{2}$ & 57.7 & 59.7 & 58.9 & 57.8 & 58.1 & 57.8 & 60.1 \\
\hline $\mathrm{TiO}_{2}$ & 0.03 & 0.00 & 0.00 & 0.00 & 0.00 & 0.00 & 0.00 \\
\hline $\mathrm{Al}_{2} \mathrm{O}_{3}$ & 26.6 & 26.0 & 26.3 & 27.0 & 26.9 & 27.2 & 25.7 \\
\hline $\mathrm{FeO}$ & 0.15 & 0.10 & 0.16 & 0.17 & 0.16 & 0.14 & 0.13 \\
\hline $\mathrm{MgO}$ & n.d. & n.d. & n.d. & 0.03 & 0.0 & 0.02 & 0.00 \\
\hline $\mathrm{BaO}$ & 0.09 & n.d. & 0.07 & 0.05 & 0.07 & 0.09 & 0.13 \\
\hline $\mathrm{CaO}$ & 9.3 & 7.8 & 8.6 & 9.3 & 9.4 & 9.1 & 7.4 \\
\hline $\mathrm{Na}_{2} \mathrm{O}$ & 6.30 & 7.1 & 6.6 & 6.23 & 6.17 & 6.27 & 7.3 \\
\hline $\mathrm{K}_{2} \mathrm{O}$ & 0.13 & 0.06 & 0.07 & 0.10 & 0.07 & 0.05 & 0.07 \\
\hline Total & 100.3 & 100.8 & 100.7 & 100.7 & 100.9 & 100.7 & 100.8 \\
\hline \multicolumn{8}{|c|}{ Stoichiometry based on 8 oxygens } \\
\hline $\mathrm{Si}$ & 2.582 & 2.642 & 2.618 & 2.575 & 2.583 & 2.573 & 2.660 \\
\hline $\mathrm{Ti}$ & 0.000 & 0.000 & 0.000 & 0.000 & 0.000 & 0.000 & 0.000 \\
\hline $\mathrm{Al}$ & 1.402 & 1.358 & 1.375 & 1.416 & 1.407 & 1.426 & 1.339 \\
\hline $\mathrm{Fe}$ & 0.006 & 0.004 & 0.006 & 0.006 & 0.006 & 0.005 & 0.005 \\
\hline $\mathrm{Mg}$ & 0.000 & 0.000 & 0.000 & 0.002 & 0.000 & 0.001 & 0.000 \\
\hline $\mathrm{Ba}$ & 0.002 & 0.000 & 0.001 & 0.001 & 0.001 & 0.002 & 0.002 \\
\hline $\mathrm{Ca}$ & 0.447 & 0.370 & 0.410 & 0.444 & 0.449 & 0.435 & 0.350 \\
\hline $\mathrm{Na}$ & 0.546 & 0.606 & 0.567 & 0.539 & 0.531 & 0.541 & 0.622 \\
\hline $\mathrm{K}$ & 0.007 & 0.004 & 0.004 & 0.006 & 0.004 & 0.003 & 0.004 \\
\hline \multicolumn{8}{|c|}{ End-member proportions } \\
\hline $\mathrm{Ab}$ & 54.5 & 61.8 & 57.7 & 54.4 & 53.9 & 55.1 & 63.5 \\
\hline An & 44.5 & 37.7 & 41.7 & 44.9 & 45.5 & 44.3 & 35.8 \\
\hline Or & 0.8 & 0.4 & 0.4 & 0.6 & 0.4 & 0.4 & 0.4 \\
\hline $\mathrm{Cn}$ & 0.2 & 0.1 & 0.2 & 0.1 & 0.2 & 0.2 & 0.3 \\
\hline
\end{tabular}




\begin{tabular}{|c|c|c|c|c|c|c|c|}
\hline \multicolumn{8}{|c|}{ EE-3A 12438-51C plagioclase (amphibolite, core 4) continued } \\
\hline & Plag 9 & Plag 10 & Plag 11 & Plag 12 & Plag 13 & Plag 14 & Plag 15 \\
\hline \multicolumn{8}{|c|}{ Weight percent } \\
\hline $\mathrm{SiO}_{2}$ & 59.4 & 58.8 & 59.2 & 58.5 & 57.8 & 58.3 & 58.5 \\
\hline $\mathrm{TiO}_{2}$ & 0.00 & 0.00 & 0.00 & 0.00 & 0.00 & 0.00 & 0.00 \\
\hline $\mathrm{Al}_{2} \mathrm{O}_{3}$ & 26.1 & 26.6 & 26.1 & 26.7 & 27.1 & 26.6 & 26.8 \\
\hline $\mathrm{FeO}$ & 0.08 & 0.04 & 0.06 & 0.08 & 0.14 & 0.11 & 0.10 \\
\hline $\mathrm{MgO}$ & 0.00 & 0.00 & n.d. & 0.00 & 0.00 & n.d. & 0.00 \\
\hline $\mathrm{BaO}$ & 0.08 & 0.05 & 0.08 & 0.07 & 0.12 & n.d. & 0.12 \\
\hline $\mathrm{CaO}$ & 8.4 & 8.8 & 8.4 & 8.7 & 9.6 & 8.8 & 8.8 \\
\hline $\mathrm{Na}_{2} \mathrm{O}$ & 6.8 & 6.4 & 6.7 & 6.5 & 6.1 & 6.6 & 6.5 \\
\hline $\mathrm{K}_{2} \mathrm{O}$ & 0.08 & 0.07 & 0.05 & 0.07 & 0.07 & 0.06 & 0.09 \\
\hline Total & 100.9 & 100.8 & 100.6 & 100.6 & 100.9 & 100.5 & 100.9 \\
\hline \multicolumn{8}{|c|}{ Stoichiometry based on 8 oxygens } \\
\hline $\mathrm{Si}$ & 2.629 & 2.608 & 2.627 & 2.599 & 2.572 & 2.596 & 2.594 \\
\hline $\mathrm{Ti}$ & 0.000 & 0.000 & 0.000 & 0.000 & 0.000 & 0.000 & 0.000 \\
\hline $\mathrm{Al}$ & 1.363 & 1.390 & 1.368 & 1.400 & 1.420 & 1.398 & 1.404 \\
\hline $\mathrm{Fe}$ & 0.003 & 0.002 & 0.002 & 0.003 & 0.005 & 0.004 & 0.004 \\
\hline $\mathrm{Mg}$ & 0.000 & 0.000 & 0.001 & 0.000 & 0.000 & 0.000 & 0.000 \\
\hline $\mathrm{Ba}$ & 0.001 & 0.001 & 0.001 & 0.001 & 0.002 & 0.000 & 0.002 \\
\hline $\mathrm{Ca}$ & 0.398 & 0.418 & 0.398 & 0.415 & 0.457 & 0.418 & 0.418 \\
\hline $\mathrm{Na}$ & 0.585 & 0.554 & 0.580 & 0.562 & 0.522 & 0.568 & 0.558 \\
\hline K & 0.004 & 0.004 & 0.003 & 0.004 & 0.004 & 0.004 & 0.005 \\
\hline \multicolumn{8}{|c|}{ End-member proportions } \\
\hline $\mathrm{Ab}$ & 59.1 & 56.7 & 59.0 & 57.2 & 53.0 & 57.3 & 56.7 \\
\hline An & 40.2 & 42.7 & 40.5 & 42.2 & 46.4 & 42.2 & 42.5 \\
\hline Or & 0.5 & 0.5 & 0.3 & 0.5 & 0.4 & 0.4 & 0.6 \\
\hline $\mathrm{Cn}$ & 0.2 & 0.1 & 0.2 & 0.1 & 0.2 & 0.1 & 0.2 \\
\hline
\end{tabular}




\begin{tabular}{|c|c|c|c|c|c|c|c|}
\hline \multicolumn{8}{|c|}{ EE-2 12849-3 plagioclase (biotite-plagioclase rock, core 2) } \\
\hline & \multicolumn{7}{|c|}{ groundmass } \\
\hline & & & & & & center & rim \\
\hline & B-3 & B-4 & B-5 & C-5 & C-6 & D-1 & D-2 \\
\hline \multicolumn{8}{|c|}{ Weight percent } \\
\hline $\mathrm{SiO}_{2}$ & 59.1 & 61.3 & 58.6 & 59.8 & 60.4 & 59.3 & 61.0 \\
\hline $\mathrm{TiO}_{2}$ & 0.00 & 0.00 & 0.02 & 0.00 & 0.03 & 0.00 & 0.00 \\
\hline $\mathrm{Al}_{2} \mathrm{O}_{3}$ & 24.4 & 24.8 & 24.7 & 25.5 & 25.1 & 26.4 & 24.8 \\
\hline $\mathrm{FeO}$ & 0.11 & 0.06 & 0.04 & 0.06 & 0.13 & 0.05 & 0.19 \\
\hline $\mathrm{MgO}$ & 0.00 & 0.00 & 0.00 & 0.00 & 0.00 & 0.00 & 0.00 \\
\hline $\mathrm{BaO}$ & 0.10 & 0.00 & 0.19 & n.d. & 0.17 & 0.00 & 0.00 \\
\hline $\mathrm{CaO}$ & 6.6 & 5.5 & 7.7 & 6.5 & 5.7 & 7.2 & 5.4 \\
\hline $\mathrm{Na}_{2} \mathrm{O}$ & 8.8 & 9.1 & 8.6 & 8.5 & 8.9 & 7.7 & 9.1 \\
\hline $\mathrm{K}_{2} \mathrm{O}$ & 0.12 & 0.10 & 0.09 & 0.11 & 0.10 & 0.10 & 0.14 \\
\hline Total & 99.2 & 100.9 & 99.9 & 100.5 & 100.5 & 100.8 & 100.6 \\
\hline \multicolumn{8}{|c|}{ Stoichiometry based on 8 oxygens } \\
\hline $\mathrm{Si}$ & 2.670 & 2.705 & 2.639 & 2.657 & 2.683 & 2.627 & 2.702 \\
\hline $\mathrm{Ti}$ & 0.000 & 0.000 & 0.001 & 0.000 & 0.001 & 0.000 & 0.000 \\
\hline $\mathrm{Al}$ & 1.297 & 1.290 & 1.310 & 1.337 & 1.311 & 1.379 & 1.292 \\
\hline $\mathrm{Fe}$ & 0.004 & 0.002 & 0.001 & 0.002 & 0.005 & 0.002 & 0.007 \\
\hline $\mathrm{Mg}$ & 0.000 & 0.000 & 0.000 & 0.000 & 0.000 & 0.000 & 0.000 \\
\hline $\mathrm{Ba}$ & 0.002 & 0.000 & 0.003 & 0.000 & 0.003 & 0.000 & 0.000 \\
\hline $\mathrm{Ca}$ & 0.319 & 0.259 & 0.372 & 0.311 & 0.272 & 0.344 & 0.255 \\
\hline $\mathrm{Na}$ & 0.771 & 0.780 & 0.753 & 0.730 & 0.764 & 0.657 & 0.784 \\
\hline $\mathrm{K}$ & 0.007 & 0.006 & 0.005 & 0.006 & 0.006 & 0.006 & 0.008 \\
\hline \multicolumn{8}{|c|}{ End-member proportions } \\
\hline $\mathrm{Ab}$ & 70.2 & 74.6 & 66.5 & 69.7 & 73.1 & 65.3 & 74.9 \\
\hline An & 29.0 & 24.8 & 32.8 & 29.7 & 26.1 & 34.1 & 24.4 \\
\hline Or & 0.6 & 0.6 & 0.4 & 0.6 & 0.5 & 0.6 & 0.7 \\
\hline $\mathrm{Cn}$ & 0.2 & 0.0 & 0.3 & 0.0 & 0.3 & 0.0 & 0.0 \\
\hline
\end{tabular}




\begin{tabular}{|c|c|c|c|c|c|c|c|}
\hline \multicolumn{8}{|c|}{ EE-2 12849-3 plagioclase (biotite-plagioclase rock, core 2) continued } \\
\hline & \multicolumn{2}{|c|}{ 1-mm megacryst } & \multicolumn{3}{|c|}{ 0.5-mm megacryst } & \multirow[b]{3}{*}{ X-2 } & \multirow[b]{3}{*}{$\mathbf{X - 3}$} \\
\hline & \multirow{2}{*}{$\begin{array}{c}\text { core } \\
\text { B-1 }\end{array}$} & \multirow{2}{*}{$\begin{array}{l}\text { rim } \\
\text { B-2 }\end{array}$} & \multicolumn{2}{|l|}{ core } & rim & & \\
\hline & & & C-1 & C-2 & C-3 & & \\
\hline \multicolumn{8}{|c|}{ Weight percent } \\
\hline $\mathrm{SiO}_{2}$ & 60.1 & 59.9 & 61.0 & 60.3 & 61.3 & 61.7 & 61.6 \\
\hline $\mathrm{TiO}_{2}$ & 0.00 & 0.00 & 0.00 & 0.00 & 0.00 & 0.02 & 0.09 \\
\hline $\mathrm{Al}_{2} \mathrm{O}_{3}$ & 25.0 & 25.5 & 24.8 & 25.0 & 24.1 & 24.5 & 24.7 \\
\hline $\mathrm{FeO}$ & 0.17 & 0.04 & 0.10 & n.d. & 0.00 & 0.04 & n.d. \\
\hline $\mathrm{MgO}$ & 0.00 & 0.00 & 0.00 & 0.00 & 0.00 & 0.00 & 0.00 \\
\hline $\mathrm{BaO}$ & 0.00 & 0.00 & 0.00 & 0.00 & 0.12 & 0.00 & 0.00 \\
\hline $\mathrm{CaO}$ & 5.9 & 6.2 & 5.7 & 6.0 & 5.1 & 5.1 & 5.4 \\
\hline $\mathrm{Na}_{2} \mathrm{O}$ & 8.9 & 8.6 & 8.8 & 8.7 & 9.2 & 9.2 & 8.7 \\
\hline $\mathrm{K}_{2} \mathrm{O}$ & 0.21 & 0.09 & 0.17 & 0.10 & 0.13 & 0.14 & 0.08 \\
\hline Total & 100.3 & 100.3 & 100.6 & 100.1 & 100.0 & 100.7 & 100.6 \\
\hline \multicolumn{8}{|c|}{ Stoichiometry based on 8 oxygens } \\
\hline $\mathrm{Si}$ & 2.677 & 2.662 & 2.700 & 2.683 & 2.727 & 2.722 & 2.719 \\
\hline $\mathrm{Ti}$ & 0.000 & 0.000 & 0.000 & 0.000 & 0.000 & 0.001 & 0.003 \\
\hline $\mathrm{Al}$ & 1.311 & 1.337 & 1.296 & 1.311 & 1.266 & 1.275 & 1.283 \\
\hline $\mathrm{Fe}$ & 0.006 & 0.002 & 0.004 & 0.000 & 0.000 & 0.001 & 0.000 \\
\hline $\mathrm{Mg}$ & 0.000 & 0.000 & 0.000 & 0.000 & 0.000 & 0.000 & 0.000 \\
\hline $\mathrm{Ba}$ & 0.000 & 0.000 & 0.000 & 0.000 & 0.002 & 0.000 & 0.000 \\
\hline $\mathrm{Ca}$ & 0.283 & 0.297 & 0.269 & 0.287 & 0.243 & 0.242 & 0.258 \\
\hline $\mathrm{Na}$ & 0.767 & 0.738 & 0.758 & 0.751 & 0.797 & 0.789 & 0.741 \\
\hline $\mathrm{K}$ & 0.012 & 0.005 & 0.009 & 0.005 & 0.007 & 0.008 & 0.005 \\
\hline \multicolumn{8}{|c|}{ End-member proportions } \\
\hline $\mathrm{Ab}$ & 72.3 & 71.0 & 73.2 & 72.0 & 76.0 & 76.0 & 73.9 \\
\hline An & 26.6 & 28.5 & 25.9 & 27.5 & 23.1 & 23.3 & 25.7 \\
\hline Or & 1.1 & 0.5 & 0.9 & 0.5 & 0.7 & 0.7 & 0.4 \\
\hline $\mathrm{Cn}$ & 0.0 & 0.0 & 0.0 & 0.0 & 0.2 & 0.0 & 0.0 \\
\hline
\end{tabular}




\begin{tabular}{|c|c|c|c|c|c|c|c|}
\hline \multicolumn{8}{|c|}{ EE-2 12852-1C plagioclase (biotite-plagioclase rock, core 2) } \\
\hline & \multicolumn{3}{|c|}{ 0.7-mm crystal } & \multicolumn{4}{|c|}{ 1.6-mm crystal } \\
\hline & \multicolumn{2}{|l|}{ core } & rim & core & & & rim \\
\hline & A-1 & A-2 & A-3 & B-4 & B-3 & B-2 & B-1 \\
\hline \multicolumn{8}{|c|}{ Weight percent } \\
\hline $\mathrm{SiO}_{2}$ & 62.9 & 62.0 & 62.5 & 55.1 & 55.7 & 60.8 & 63.2 \\
\hline $\mathrm{TiO}_{2}$ & 0.00 & 0.00 & 0.00 & 0.00 & 0.03 & 0.03 & 0.05 \\
\hline $\mathrm{Al}_{2} \mathrm{O}_{3}$ & 24.1 & 24.4 & 24.2 & 29.2 & 28.4 & 25.2 & 25.0 \\
\hline $\mathrm{FeO}$ & 0.10 & 0.08 & 0.17 & 0.17 & 0.46 & 0.08 & 0.13 \\
\hline $\mathrm{MgO}$ & 0.00 & 0.00 & 0.00 & 0.04 & 0.02 & 0.00 & 0.00 \\
\hline $\mathrm{BaO}$ & n.d. & n.d. & 0.00 & 0.00 & 0.00 & 0.00 & 0.00 \\
\hline $\mathrm{CaO}$ & 4.64 & 5.30 & 5.55 & 10.7 & 9.6 & 6.1 & 5.7 \\
\hline $\mathrm{Na}_{2} \mathrm{O}$ & 9.2 & 8.9 & 8.3 & 5.54 & 6.07 & 8.3 & 5.48 \\
\hline $\mathrm{K}_{2} \mathrm{O}$ & 0.12 & 0.11 & 0.08 & 0.14 & 0.11 & 0.11 & 0.16 \\
\hline Total & 101.1 & 100.8 & 100.8 & 100.9 & 100.4 & 100.6 & 99.7 \\
\hline \multicolumn{8}{|c|}{ Stoichiometry based on 8 oxygens } \\
\hline $\mathrm{Si}$ & 2.758 & 2.731 & 2.746 & 2.464 & 2.499 & 2.689 & 2.771 \\
\hline $\mathrm{Ti}$ & 0.000 & 0.000 & 0.000 & 0.000 & 0.001 & 0.001 & 0.002 \\
\hline $\mathrm{Al}$ & 1.246 & 1.267 & 1.256 & 1.539 & 1.502 & 1.313 & 1.295 \\
\hline $\mathrm{Fe}$ & 0.004 & 0.003 & 0.006 & 0.006 & 0.017 & 0.003 & 0.005 \\
\hline $\mathrm{Mg}$ & 0.000 & 0.000 & 0.000 & 0.003 & 0.002 & 0.000 & 0.000 \\
\hline $\mathrm{Ba}$ & 0.000 & 0.000 & 0.000 & 0.000 & 0.000 & 0.000 & 0.000 \\
\hline $\mathrm{Ca}$ & 0.218 & 0.251 & 0.262 & 0.511 & 0.461 & 0.287 & 0.270 \\
\hline $\mathrm{Na}$ & 0.778 & 0.760 & 0.710 & 0.480 & 0.529 & 0.714 & 0.466 \\
\hline $\mathrm{K}$ & 0.006 & 0.006 & 0.005 & 0.008 & 0.006 & 0.006 & 0.009 \\
\hline \multicolumn{8}{|c|}{ End-member proportions } \\
\hline $\mathrm{Ab}$ & 77.6 & 74.8 & 72.7 & 48.1 & 53.1 & 70.9 & 62.6 \\
\hline An & 21.7 & 24.6 & 26.8 & 51.1 & 46.3 & 28.5 & 36.2 \\
\hline Or & 0.7 & 0.6 & 0.5 & 0.8 & 0.6 & 0.6 & 1.2 \\
\hline $\mathrm{Cn}$ & 0.0 & 0.0 & 0.0 & 0.0 & 0.0 & 0.0 & 0.0 \\
\hline
\end{tabular}




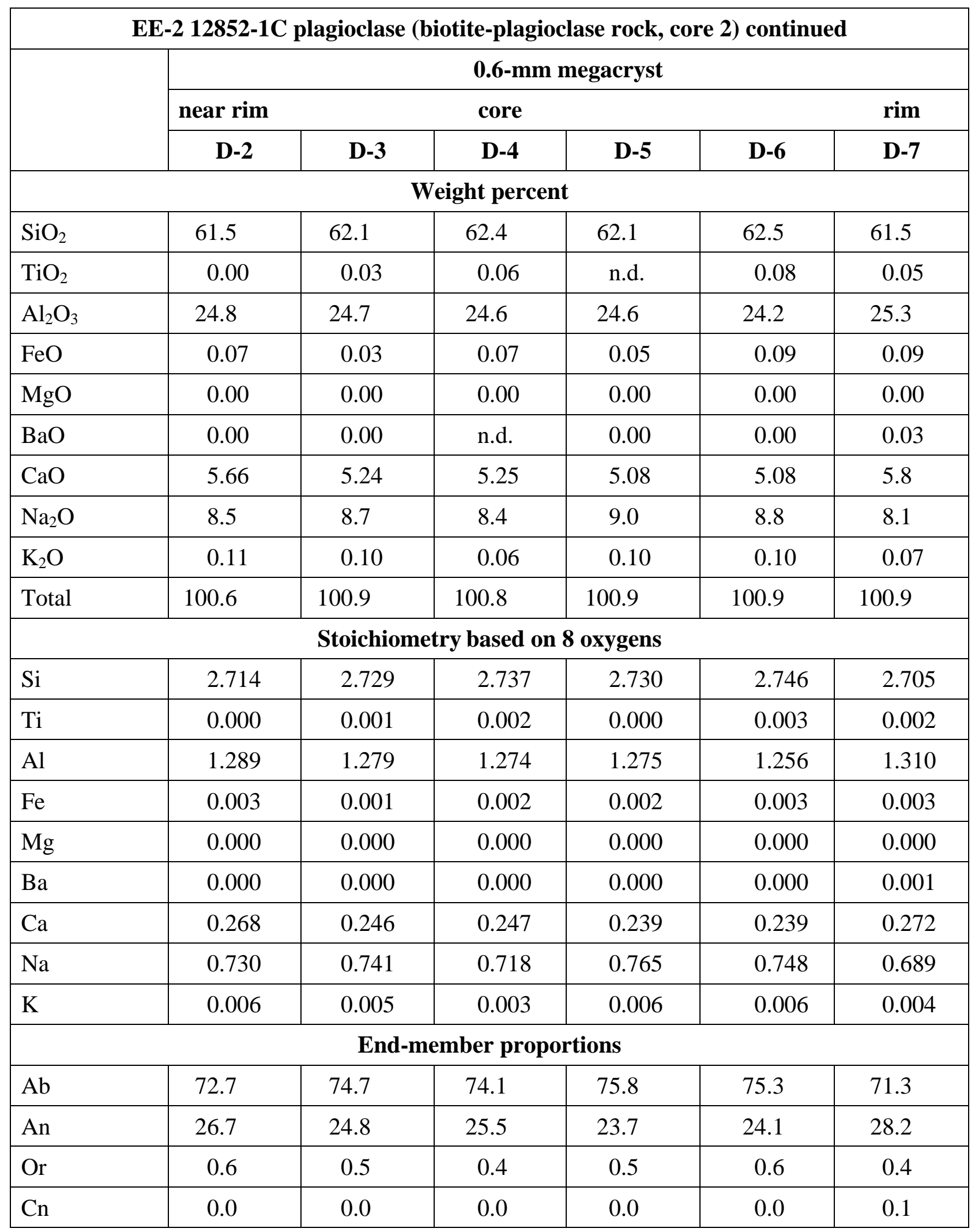




\begin{tabular}{|c|c|c|c|c|c|c|c|}
\hline \multicolumn{8}{|c|}{ EE-2 12852-1C plagioclase (biotite-plagioclase rock, core 2) continued } \\
\hline & \multicolumn{2}{|c|}{ 0.5-mm lath } & \multicolumn{2}{|c|}{ 0.3-mm lath } & \multicolumn{3}{|c|}{ groundmass } \\
\hline & C-1 & C-2 & C-4 & C-7 & B-5 & C-5 & D-1 \\
\hline \multicolumn{8}{|c|}{ Weight percent } \\
\hline $\mathrm{SiO}_{2}$ & 56.1 & 57.7 & 60.2 & 56.8 & 60.3 & 59.8 & 61.7 \\
\hline $\mathrm{TiO}_{2}$ & 0.00 & n.d. & 0.00 & 0.07 & 0.00 & 0.02 & n.d. \\
\hline $\mathrm{Al}_{2} \mathrm{O}_{3}$ & 28.5 & 27.2 & 25.5 & 28.1 & 25.2 & 25.4 & 24.7 \\
\hline $\mathrm{FeO}$ & 0.12 & 0.36 & 0.04 & 0.14 & 0.12 & 0.13 & 0.12 \\
\hline $\mathrm{MgO}$ & 0.00 & 0.07 & 0.00 & 0.00 & 0.00 & 0.00 & 0.00 \\
\hline $\mathrm{BaO}$ & 0.00 & 0.00 & 0.00 & 0.00 & 0.00 & 0.00 & n.d. \\
\hline $\mathrm{CaO}$ & 9.8 & 8.6 & 6.4 & 8.6 & 6.1 & 6.4 & 5.53 \\
\hline $\mathrm{Na}_{2} \mathrm{O}$ & 6.15 & 6.61 & 7.9 & 6.42 & 8.5 & 8.2 & 8.5 \\
\hline $\mathrm{K}_{2} \mathrm{O}$ & 0.07 & 0.30 & 0.07 & 0.45 & 0.09 & 0.06 & 0.08 \\
\hline Total & 100.7 & 100.8 & 100.1 & 100.6 & 100.3 & 100.0 & 100.6 \\
\hline \multicolumn{8}{|c|}{ Stoichiometry based on 8 oxygens } \\
\hline $\mathrm{Si}$ & 2.504 & 2.567 & 2.675 & 2.534 & 2.679 & 2.665 & 2.720 \\
\hline $\mathrm{Ti}$ & 0.000 & 0.000 & 0.000 & 0.002 & 0.000 & 0.001 & 0.000 \\
\hline $\mathrm{Al}$ & 1.498 & 1.428 & 1.335 & 1.479 & 1.318 & 1.335 & 1.284 \\
\hline $\mathrm{Fe}$ & 0.004 & 0.013 & 0.001 & 0.005 & 0.004 & 0.005 & 0.005 \\
\hline $\mathrm{Mg}$ & 0.000 & 0.005 & 0.000 & 0.000 & 0.000 & 0.000 & 0.000 \\
\hline $\mathrm{Ba}$ & 0.000 & 0.000 & 0.000 & 0.000 & 0.000 & 0.000 & 0.000 \\
\hline $\mathrm{Ca}$ & 0.471 & 0.411 & 0.306 & 0.413 & 0.291 & 0.306 & 0.261 \\
\hline $\mathrm{Na}$ & 0.533 & 0.571 & 0.678 & 0.555 & 0.732 & 0.708 & 0.730 \\
\hline $\mathrm{K}$ & 0.004 & 0.017 & 0.004 & 0.026 & 0.005 & 0.003 & 0.004 \\
\hline \multicolumn{8}{|c|}{ End-member proportions } \\
\hline $\mathrm{Ab}$ & 52.9 & 57.1 & 68.6 & 55.9 & 71.2 & 69.7 & 73.4 \\
\hline An & 46.7 & 41.2 & 31.0 & 41.5 & 28.3 & 30.0 & 26.2 \\
\hline Or & 0.4 & 1.7 & 0.4 & 2.6 & 0.5 & 0.3 & 0.4 \\
\hline $\mathrm{Cn}$ & 0.0 & 0.0 & 0.0 & 0.0 & 0.0 & 0.0 & 0.0 \\
\hline
\end{tabular}




\begin{tabular}{|c|c|c|c|c|}
\hline \multicolumn{5}{|c|}{ EE-3A 12230-40 plagioclase (biotite-plagioclase rock, cuttings) } \\
\hline & A-5 & A-9 & A-10 & A-12 \\
\hline \multicolumn{5}{|c|}{ Weight percent } \\
\hline $\mathrm{SiO}_{2}$ & 69.6 & 61.4 & 62.1 & 61.3 \\
\hline $\mathrm{TiO}_{2}$ & 0.04 & 0.00 & 0.07 & 0.00 \\
\hline $\mathrm{Al}_{2} \mathrm{O}_{3}$ & 18.9 & 24.9 & 24.4 & 24.3 \\
\hline $\mathrm{FeO}$ & 0.00 & 0.15 & 0.18 & 0.09 \\
\hline $\mathrm{MgO}$ & 0.00 & 0.00 & 0.00 & 0.00 \\
\hline $\mathrm{BaO}$ & 0.00 & 0.00 & 0.00 & 0.00 \\
\hline $\mathrm{CaO}$ & 1.09 & 5.58 & 5.00 & 5.18 \\
\hline $\mathrm{Na}_{2} \mathrm{O}$ & 10.5 & 8.8 & 8.9 & 8.9 \\
\hline $\mathrm{K}_{2} \mathrm{O}$ & 0.19 & 0.13 & 0.13 & 0.11 \\
\hline Total & 100.3 & 101.0 & 100.8 & 99.9 \\
\hline \multicolumn{5}{|c|}{ Stoichiometry based on 8 oxygens } \\
\hline $\mathrm{Si}$ & 3.024 & 2.705 & 2.736 & 2.726 \\
\hline $\mathrm{Ti}$ & 0.001 & 0.000 & 0.002 & 0.000 \\
\hline $\mathrm{Al}$ & 0.970 & 1.295 & 1.267 & 1.273 \\
\hline $\mathrm{Fe}$ & 0.000 & 0.006 & 0.007 & 0.003 \\
\hline $\mathrm{Mg}$ & 0.000 & 0.000 & 0.000 & 0.000 \\
\hline $\mathrm{Ba}$ & 0.000 & 0.000 & 0.000 & 0.000 \\
\hline $\mathrm{Ca}$ & 0.051 & 0.264 & 0.236 & 0.247 \\
\hline $\mathrm{Na}$ & 0.880 & 0.750 & 0.755 & 0.771 \\
\hline $\mathrm{K}$ & 0.011 & 0.007 & 0.007 & 0.006 \\
\hline \multicolumn{5}{|c|}{ End-member proportions } \\
\hline $\mathrm{Ab}$ & 93.5 & 73.5 & 75.6 & 75.3 \\
\hline An & 5.4 & 25.8 & 23.6 & 24.1 \\
\hline Or & 1.1 & 0.7 & 0.8 & 0.6 \\
\hline $\mathrm{Cn}$ & 0.0 & 0.0 & 0.0 & 0.0 \\
\hline
\end{tabular}




\begin{tabular}{|c|c|c|c|c|c|}
\hline \multicolumn{6}{|c|}{ EE-3A 12270-80B plagioclase (biotite-plagioclase rock, cuttings) } \\
\hline & A-1 & A-3 & A-5 & A-6 & A-8 \\
\hline \multicolumn{6}{|c|}{ Weight percent } \\
\hline $\mathrm{SiO}_{2}$ & 58.5 & 62.1 & 56.4 & 61.6 & 69.3 \\
\hline $\mathrm{TiO}_{2}$ & 0.00 & 0.00 & 0.00 & 0.04 & 0.00 \\
\hline $\mathrm{Al}_{2} \mathrm{O}_{3}$ & 26.7 & 24.0 & 28.1 & 24.2 & 19.4 \\
\hline $\mathrm{FeO}$ & 0.08 & 0.08 & n.d. & 0.09 & 0.09 \\
\hline $\mathrm{MgO}$ & 0.00 & 0.00 & 0.00 & 0.00 & 0.00 \\
\hline $\mathrm{BaO}$ & 0.00 & 0.10 & n.d. & n.d. & 0.00 \\
\hline $\mathrm{CaO}$ & 8.0 & 4.9 & 9.3 & 5.0 & 3.6 \\
\hline $\mathrm{Na}_{2} \mathrm{O}$ & 7.6 & 9.2 & 6.7 & 9.1 & 7.7 \\
\hline $\mathrm{K}_{2} \mathrm{O}$ & 0.05 & 0.12 & 0.07 & 0.13 & 0.06 \\
\hline Total & 100.9 & 100.5 & 100.6 & 100.2 & 100.2 \\
\hline \multicolumn{6}{|c|}{ Stoichiometry based on 8 oxygens } \\
\hline $\mathrm{Si}$ & 2.600 & 2.746 & 2.519 & 2.732 & 3.006 \\
\hline $\mathrm{Ti}$ & 0.000 & 0.000 & 0.000 & 0.001 & 0.000 \\
\hline $\mathrm{Al}$ & 1.397 & 1.251 & 1.481 & 1.265 & 0.994 \\
\hline $\mathrm{Fe}$ & 0.000 & 0.003 & 0.000 & 0.003 & 0.003 \\
\hline $\mathrm{Mg}$ & 0.000 & 0.000 & 0.000 & 0.000 & 0.000 \\
\hline $\mathrm{Ba}$ & 0.000 & 0.002 & 0.000 & 0.000 & 0.000 \\
\hline $\mathrm{Ca}$ & 0.379 & 0.231 & 0.447 & 0.240 & 0.167 \\
\hline $\mathrm{Na}$ & 0.651 & 0.785 & 0.579 & 0.780 & 0.650 \\
\hline $\mathrm{K}$ & 0.003 & 0.007 & 0.004 & 0.007 & 0.003 \\
\hline \multicolumn{6}{|c|}{ End-member proportions } \\
\hline $\mathrm{Ab}$ & 63.1 & 76.6 & 56.2 & 76.0 & 79.2 \\
\hline An & 36.6 & 22.5 & 43.4 & 23.3 & 20.4 \\
\hline Or & 0.3 & 0.7 & 0.4 & 0.7 & 0.4 \\
\hline $\mathrm{Cn}$ & 0.0 & 0.2 & 0.0 & 0.0 & 0.0 \\
\hline
\end{tabular}




\begin{tabular}{|c|c|c|c|c|c|}
\hline \multicolumn{6}{|c|}{ EE-3A 10877.7 microcline and perthite (leucogranite, core 2) } \\
\hline & \multicolumn{3}{|c|}{ microcline } & \multicolumn{2}{|c|}{ perthite lamellae in $\mathrm{B} 1 \mathrm{~A}-2$ crystal } \\
\hline & A1-1 & A1-2 & B1A-2 & B1A-1 & B1A-6 \\
\hline \multicolumn{6}{|c|}{ Weight percent } \\
\hline $\mathrm{SiO}_{2}$ & 64.3 & 65.2 & 64.9 & 68.4 & 68.2 \\
\hline $\mathrm{TiO}_{2}$ & 0.04 & n.d. & 0.02 & 0.00 & n.d. \\
\hline $\mathrm{Al}_{2} \mathrm{O}_{3}$ & 18.0 & 18.0 & 18.3 & 19.5 & 20.0 \\
\hline $\mathrm{FeO}$ & 0.05 & 0.05 & 0.05 & 0.00 & 0.00 \\
\hline $\mathrm{MgO}$ & 0.00 & 0.00 & 0.00 & 0.00 & 0.00 \\
\hline $\mathrm{BaO}$ & 0.00 & n.d. & 0.06 & 0.00 & n.d. \\
\hline $\mathrm{CaO}$ & 0.00 & 0.00 & 0.00 & 0.06 & 0.10 \\
\hline $\mathrm{Na}_{2} \mathrm{O}$ & 0.72 & 0.42 & 0.45 & 11.6 & 12.2 \\
\hline $\mathrm{K}_{2} \mathrm{O}$ & 16.7 & 16.3 & 16.4 & 0.23 & 0.19 \\
\hline Total & 99.8 & 100.0 & 100.2 & 99.8 & 100.7 \\
\hline \multicolumn{6}{|c|}{ Stoichiometry based on 8 oxygens } \\
\hline $\mathrm{Si}$ & 2.993 & 3.013 & 2.998 & 2.992 & 2.967 \\
\hline $\mathrm{Ti}$ & 0.001 & 0.000 & 0.001 & 0.000 & 0.000 \\
\hline $\mathrm{Al}$ & 0.989 & 0.981 & 0.997 & 1.008 & 1.028 \\
\hline $\mathrm{Fe}$ & 0.002 & 0.002 & 0.002 & 0.000 & 0.000 \\
\hline $\mathrm{Mg}$ & 0.000 & 0.000 & 0.000 & 0.000 & 0.000 \\
\hline $\mathrm{Ba}$ & 0.000 & 0.000 & 0.001 & 0.000 & 0.000 \\
\hline $\mathrm{Ca}$ & 0.000 & 0.000 & 0.000 & 0.003 & 0.005 \\
\hline $\mathrm{Na}$ & 0.065 & 0.038 & 0.040 & 0.988 & 1.026 \\
\hline $\mathrm{K}$ & 0.990 & 0.961 & 0.968 & 0.013 & 0.010 \\
\hline \multicolumn{6}{|c|}{ End-member proportions } \\
\hline $\mathrm{Ab}$ & 6.1 & 3.8 & 4.0 & 98.4 & 98.6 \\
\hline An & 0.0 & 0.0 & 0.0 & 0.3 & 0.4 \\
\hline Or & 93.9 & 96.2 & 95.9 & 1.3 & 1.0 \\
\hline $\mathrm{Cn}$ & 0.0 & 0.0 & 0.1 & 0.0 & 0.0 \\
\hline
\end{tabular}




\begin{tabular}{|c|c|c|c|c|c|c|c|}
\hline \multicolumn{8}{|c|}{ Biotite in granitic rocks, EE-3A } \\
\hline & \multicolumn{2}{|c|}{$\begin{array}{l}9450-5 C-B \text { core } 1 \\
\text { recrystallized } \\
\text { amphibolite in } \\
\text { leucogranite dike }\end{array}$} & \multicolumn{2}{|c|}{$\begin{array}{l}\text { 11600-2 core } 3 \\
\text { granodiorite }\end{array}$} & \multicolumn{3}{|c|}{$\begin{array}{c}\text { 11615-8A core } 3 \\
\text { biotite monzogranite }\end{array}$} \\
\hline & A-11 & A-12 & A-2 & A-3 & A-8 & A-9 & A-10 \\
\hline \multicolumn{8}{|c|}{ Weight percent } \\
\hline $\mathrm{SiO}_{2}$ & 37.3 & 37.4 & 37.1 & 36.7 & 35.9 & 36.1 & 35.7 \\
\hline $\mathrm{TiO}_{2}$ & 1.4 & 1.7 & 1.5 & 1.6 & 3.1 & 1.4 & 2.5 \\
\hline $\mathrm{Al}_{2} \mathrm{O}_{3}$ & 16.2 & 16.0 & 15.9 & 15.8 & 15.5 & 15.8 & 16.1 \\
\hline $\mathrm{FeO}$ & 17.9 & 16.7 & 16.1 & 16.5 & 20.2 & 19.0 & 19.5 \\
\hline $\mathrm{MnO}$ & 0.34 & 0.33 & 0.53 & 0.54 & 0.74 & 0.62 & 0.78 \\
\hline $\mathrm{MgO}$ & 13.9 & 13.3 & 13.6 & 12.8 & 9.6 & 10.8 & 9.9 \\
\hline $\mathrm{CaO}$ & n.d. & n.d. & 0.04 & 0.04 & 0.00 & n.d. & 0.00 \\
\hline $\mathrm{Na}_{2} \mathrm{O}$ & 0.00 & 0.00 & n.d. & n.d. & 0.00 & 0.00 & 0.00 \\
\hline $\mathrm{K}_{2} \mathrm{O}$ & 9.1 & 9.5 & 9.7 & 9.3 & 9.4 & 9.4 & 9.5 \\
\hline $\mathrm{F}$ & n.d. & n.d. & 0.00 & n.d. & 0.00 & n.d. & 0.00 \\
\hline $\mathrm{Cl}$ & n.d. & n.d. & n.d. & 0.00 & n.d. & n.d. & n.d. \\
\hline Total & 96.1 & 94.9 & 94.5 & 93.3 & 94.4 & 93.1 & 94.0 \\
\hline \multicolumn{8}{|c|}{ Stoichiometry based on 11 oxygens } \\
\hline $\mathrm{Si}$ & 2.906 & 2.946 & 2.940 & 2.944 & 2.908 & 2.945 & 2.899 \\
\hline $\mathrm{Ti}$ & 0.081 & 0.099 & 0.089 & 0.094 & 0.191 & 0.088 & 0.154 \\
\hline $\mathrm{Al}$ & 1.485 & 1.481 & 1.489 & 1.495 & 1.480 & 1.520 & 1.543 \\
\hline $\mathrm{Fe}$ & 1.164 & 1.100 & 1.070 & 1.108 & 1.370 & 1.296 & 1.325 \\
\hline $\mathrm{Mn}$ & 0.022 & 0.022 & 0.036 & 0.037 & 0.051 & 0.043 & 0.054 \\
\hline $\mathrm{Mg}$ & 1.613 & 1.564 & 1.603 & 1.537 & 1.160 & 1.317 & 1.201 \\
\hline $\mathrm{Ca}$ & 0.000 & 0.000 & 0.003 & 0.003 & 0.000 & 0.000 & 0.000 \\
\hline $\mathrm{Na}$ & 0.000 & 0.000 & 0.000 & 0.000 & 0.000 & 0.000 & 0.000 \\
\hline $\mathrm{K}$ & 0.903 & 0.954 & 0.986 & 0.949 & 0.970 & 0.973 & 0.987 \\
\hline $\mathrm{F}$ & 0.000 & 0.000 & 0.000 & 0.000 & 0.000 & 0.000 & 0.000 \\
\hline $\mathrm{Cl}$ & 0.000 & 0.000 & 0.000 & 0.000 & 0.000 & 0.000 & 0.000 \\
\hline $\mathrm{Mg} /(\mathrm{Mg}+\mathrm{Fe}+\mathrm{Mn})$ & 0.58 & 0.58 & 0.59 & 0.57 & 0.45 & 0.50 & 0.47 \\
\hline
\end{tabular}




\begin{tabular}{|c|c|c|c|c|c|c|c|}
\hline \multicolumn{8}{|c|}{ EE-3A 12438-14 biotite (tonalite dike in amphibolite, core 4) } \\
\hline & $\mathrm{X}-11$ & $\mathrm{X}-12$ & $\mathrm{X}-\mathbf{1 3}$ & $X-14$ & $\mathrm{X}-15$ & $\mathrm{X}-17$ & $\mathrm{X}-18$ \\
\hline \multicolumn{8}{|c|}{ Weight percent } \\
\hline $\mathrm{SiO}_{2}$ & 37.2 & 36.8 & 37.2 & 37.1 & 36.9 & 36.1 & 36.5 \\
\hline $\mathrm{TiO}_{2}$ & 2.4 & 2.7 & 2.5 & 2.0 & 2.1 & 3.5 & 2.3 \\
\hline $\mathrm{Al}_{2} \mathrm{O}_{3}$ & 16.7 & 16.0 & 15.9 & 16.4 & 16.2 & 16.2 & 16.7 \\
\hline $\mathrm{FeO}$ & 19.2 & 19.2 & 19.7 & 19.4 & 19.8 & 19.5 & 18.7 \\
\hline $\mathrm{MnO}$ & 0.26 & 0.18 & 0.31 & 0.24 & 0.36 & 0.29 & 0.25 \\
\hline $\mathrm{MgO}$ & 11.2 & 12.1 & 11.4 & 11.7 & 11.6 & 10.8 & 11.7 \\
\hline $\mathrm{CaO}$ & 0.00 & 0.00 & 0.00 & 0.00 & 0.00 & 0.00 & 0.00 \\
\hline $\mathrm{Na}_{2} \mathrm{O}$ & 0.00 & n.d. & n.d. & 0.00 & 0.00 & n.d. & 0.00 \\
\hline $\mathrm{K}_{2} \mathrm{O}$ & 9.59 & 9.45 & 9.43 & 9.40 & 9.29 & 9.24 & 9.47 \\
\hline $\mathrm{F}$ & 0.00 & n.d. & 0.00 & 0.00 & 0.00 & 0.00 & n.d. \\
\hline $\mathrm{Cl}$ & 0.00 & 0.00 & 0.00 & 0.00 & 0.00 & 0.00 & 0.00 \\
\hline Total & 96.6 & 96.4 & 96.4 & 96.2 & 96.3 & 95.6 & 95.6 \\
\hline \multicolumn{8}{|c|}{ Stoichiometry based on 11 oxygens } \\
\hline $\mathrm{Si}$ & 2.911 & 2.887 & 2.921 & 2.912 & 2.907 & 2.866 & 2.884 \\
\hline $\mathrm{Ti}$ & 0.144 & 0.162 & 0.147 & 0.119 & 0.122 & 0.206 & 0.136 \\
\hline $\mathrm{Al}$ & 1.539 & 1.479 & 1.474 & 1.519 & 1.502 & 1.512 & 1.554 \\
\hline $\mathrm{Fe}$ & 1.255 & 1.262 & 1.293 & 1.273 & 1.304 & 1.293 & 1.238 \\
\hline $\mathrm{Mn}$ & 0.017 & 0.012 & 0.021 & 0.016 & 0.024 & 0.020 & 0.017 \\
\hline $\mathrm{Mg}$ & 1.309 & 1.411 & 1.338 & 1.371 & 1.363 & 1.275 & 1.373 \\
\hline $\mathrm{Ca}$ & 0.000 & 0.000 & 0.000 & 0.000 & 0.000 & 0.000 & 0.000 \\
\hline $\mathrm{Na}$ & 0.000 & 0.000 & 0.005 & 0.000 & 0.000 & 0.000 & 0.000 \\
\hline $\mathrm{K}$ & 0.959 & 0.948 & 0.945 & 0.942 & 0.935 & 0.936 & 0.956 \\
\hline$F$ & 0.000 & 0.000 & 0.000 & 0.000 & 0.000 & 0.000 & 0.000 \\
\hline $\mathrm{Cl}$ & 0.000 & 0.000 & 0.000 & 0.000 & 0.000 & 0.000 & 0.000 \\
\hline $\mathrm{Mg} /(\mathrm{Mg}+\mathrm{Fe}+\mathrm{Mn})$ & 0.51 & 0.53 & 0.51 & 0.52 & 0.51 & 0.49 & 0.52 \\
\hline
\end{tabular}




\begin{tabular}{|c|c|c|c|c|c|c|c|}
\hline \multicolumn{8}{|c|}{ EE-3A 12438-14 biotite (recrystallized amphibolite in tonalite dike, core 4) } \\
\hline & $X-4$ & $X-5$ & $X-6$ & $X-7$ & $X-8$ & X-9 & $X-10$ \\
\hline \multicolumn{8}{|c|}{ Weight percent } \\
\hline $\mathrm{SiO}_{2}$ & 36.6 & 36.8 & 36.9 & 37.0 & 35.9 & 36.7 & 36.9 \\
\hline $\mathrm{TiO}_{2}$ & 2.3 & 1.9 & 1.7 & 2.1 & 2.1 & 1.7 & 2.0 \\
\hline $\mathrm{Al}_{2} \mathrm{O}_{3}$ & 16.3 & 16.2 & 16.3 & 16.4 & 16.1 & 15.9 & 16.1 \\
\hline $\mathrm{FeO}$ & 19.1 & 18.6 & 18.7 & 19.0 & 18.8 & 18.4 & 18.6 \\
\hline $\mathrm{MnO}$ & 0.32 & 0.27 & 0.22 & 0.33 & 0.34 & 0.34 & 0.30 \\
\hline $\mathrm{MgO}$ & 11.6 & 12.3 & 12.1 & 11.9 & 11.6 & 12.1 & 12.1 \\
\hline $\mathrm{CaO}$ & 0.00 & 0.00 & 0.00 & 0.00 & 0.00 & n.d. & 0.00 \\
\hline $\mathrm{Na}_{2} \mathrm{O}$ & 0.00 & 0.00 & 0.00 & 0.00 & 0.00 & n.d. & 0.00 \\
\hline $\mathrm{K}_{2} \mathrm{O}$ & 9.34 & 9.51 & 9.46 & 9.51 & 9.38 & 9.47 & 9.56 \\
\hline $\mathrm{F}$ & 0.00 & 0.00 & 0.00 & 0.00 & n.d. & 0.00 & n.d. \\
\hline $\mathrm{Cl}$ & 0.00 & 0.00 & 0.00 & 0.00 & 0.00 & n.d. & 0.00 \\
\hline Total & 95.6 & 95.6 & 95.4 & 96.2 & 94.2 & 94.6 & 95.6 \\
\hline \multicolumn{8}{|c|}{ Stoichiometry based on 11 oxygens } \\
\hline $\mathrm{Si}$ & 2.897 & 2.912 & 2.919 & 2.907 & 2.892 & 2.929 & 2.918 \\
\hline $\mathrm{Ti}$ & 0.136 & 0.110 & 0.102 & 0.123 & 0.129 & 0.103 & 0.118 \\
\hline $\mathrm{Al}$ & 1.520 & 1.507 & 1.524 & 1.516 & 1.523 & 1.496 & 1.505 \\
\hline $\mathrm{Fe}$ & 1.261 & 1.231 & 1.237 & 1.249 & 1.266 & 1.229 & 1.227 \\
\hline $\mathrm{Mn}$ & 0.022 & 0.018 & 0.015 & 0.022 & 0.023 & 0.023 & 0.020 \\
\hline $\mathrm{Mg}$ & 1.372 & 1.446 & 1.422 & 1.395 & 1.385 & 1.442 & 1.424 \\
\hline $\mathrm{Ca}$ & 0.000 & 0.000 & 0.000 & 0.000 & 0.000 & 0.000 & 0.000 \\
\hline $\mathrm{Na}$ & 0.000 & 0.000 & 0.000 & 0.000 & 0.000 & 0.000 & 0.000 \\
\hline $\mathrm{K}$ & 0.943 & 0.960 & 0.956 & 0.954 & 0.964 & 0.964 & 0.965 \\
\hline $\mathrm{F}$ & 0.000 & 0.000 & 0.000 & 0.000 & 0.000 & 0.000 & 0.000 \\
\hline $\mathrm{Cl}$ & 0.000 & 0.000 & 0.000 & 0.000 & 0.000 & 0.000 & 0.000 \\
\hline $\mathrm{Mg} /(\mathrm{Mg}+\mathrm{Fe}+\mathrm{Mn})$ & 0.52 & 0.54 & 0.53 & 0.52 & 0.52 & 0.54 & 0.53 \\
\hline
\end{tabular}




\begin{tabular}{|c|c|c|c|c|c|}
\hline \multicolumn{6}{|c|}{ Biotite in biotite-plagioclase rock } \\
\hline & \multirow{2}{*}{\begin{tabular}{|c|} 
EE-2 12852-1C \\
core 2 \\
$X-1$ \\
\end{tabular}} & \multicolumn{2}{|c|}{$\begin{array}{c}\text { EE-3A 12270-80 } \\
\text { bit cuttings }\end{array}$} & \multicolumn{2}{|c|}{$\begin{array}{c}\text { EE-3A 12310-20 } \\
\text { bit cuttings }\end{array}$} \\
\hline & & C1-5 & C1-6 & Biot-1 & Biot-2 \\
\hline \multicolumn{6}{|c|}{ Weight percent } \\
\hline $\mathrm{SiO}_{2}$ & 37.2 & 37.2 & 36.6 & 38.0 & 37.7 \\
\hline $\mathrm{TiO}_{2}$ & 1.85 & 2.04 & 2.08 & 1.40 & 1.61 \\
\hline $\mathrm{Al}_{2} \mathrm{O}_{3}$ & 16.7 & 15.3 & 15.4 & 16.3 & 16.2 \\
\hline $\mathrm{FeO}$ & 18.9 & 18.7 & 18.5 & 17.9 & 18.0 \\
\hline $\mathrm{MnO}$ & 0.45 & 0.52 & 0.49 & 0.46 & 0.50 \\
\hline $\mathrm{MgO}$ & 11.7 & 11.7 & 11.8 & 12.1 & 12.1 \\
\hline $\mathrm{CaO}$ & n.d. & 0.00 & 0.00 & n.d. & 0.02 \\
\hline $\mathrm{Na}_{2} \mathrm{O}$ & 0.00 & 0.07 & n.d. & 0.05 & 0.00 \\
\hline $\mathrm{K}_{2} \mathrm{O}$ & 10.0 & 9.7 & 9.8 & 9.7 & 9.6 \\
\hline $\mathrm{F}$ & 0.00 & n.a. & n.a. & n.d. & n.d. \\
\hline $\mathrm{Cl}$ & n.d. & n.a. & n.a. & n.d. & n.d. \\
\hline Total & 96.8 & 95.2 & 94.7 & 95.9 & 95.7 \\
\hline \multicolumn{6}{|c|}{ Stoichiometry based on 11 oxygens } \\
\hline $\mathrm{Si}$ & 2.915 & 2.837 & 2.810 & 2.976 & 2.962 \\
\hline $\mathrm{Ti}$ & 0.109 & 0.117 & 0.120 & 0.083 & 0.095 \\
\hline $\mathrm{Al}$ & 1.541 & 1.371 & 1.396 & 1.509 & 1.499 \\
\hline $\mathrm{Fe}$ & 1.240 & 1.191 & 1.186 & 1.172 & 1.186 \\
\hline $\mathrm{Mn}$ & 0.030 & 0.034 & 0.032 & 0.030 & 0.033 \\
\hline $\mathrm{Mg}$ & 1.362 & 1.332 & 1.348 & 1.416 & 1.415 \\
\hline $\mathrm{Ca}$ & 0.000 & 0.000 & 0.000 & 0.000 & 0.001 \\
\hline $\mathrm{Na}$ & 0.000 & 0.010 & 0.000 & 0.007 & 0.000 \\
\hline K & 0.996 & 0.943 & 0.957 & 0.967 & 0.959 \\
\hline $\mathrm{F}$ & 0.000 & 0.000 & 0.000 & 0.000 & 0.000 \\
\hline $\mathrm{Cl}$ & 0.000 & 0.000 & 0.000 & 0.000 & 0.000 \\
\hline $\mathrm{Mg} /(\mathrm{Mg}+\mathrm{Fe}+\mathrm{Mn})$ & 0.52 & 0.52 & 0.53 & 0.54 & 0.54 \\
\hline
\end{tabular}




\begin{tabular}{|c|c|c|c|c|c|c|}
\hline \multicolumn{7}{|c|}{ Residual hornblendes in granitic rocks } \\
\hline & \multicolumn{6}{|c|}{ EE-3A 9450-5C-B (monzogranite dike in amphibolite, core 1) } \\
\hline & A-1 & A-3 & A-5 & A-6 & A-9 & A-10 \\
\hline \multicolumn{7}{|c|}{ Weight Percent } \\
\hline $\mathrm{SiO}_{2}$ & 43.6 & 43.2 & 43.5 & 44.1 & 43.6 & 44.2 \\
\hline $\mathrm{TiO}_{2}$ & 1.2 & 1.8 & 0.9 & 0.93 & 1.7 & 1.5 \\
\hline $\mathrm{Al}_{2} \mathrm{O}_{3}$ & 9.7 & 9.8 & 9.8 & 9.6 & 10.2 & 9.6 \\
\hline $\mathrm{Cr}_{2} \mathrm{O}_{3}$ & n.d. & 0.06 & n.d. & 0.07 & n.d. & 0.05 \\
\hline $\mathrm{FeO}$ & 18.2 & 17.9 & 18.1 & 19.0 & 17.8 & 18.1 \\
\hline $\mathrm{MnO}$ & 0.42 & 0.50 & 0.39 & 0.43 & 0.37 & 0.39 \\
\hline $\mathrm{MgO}$ & 10.9 & 10.6 & 11.1 & 10.4 & 10.6 & 10.8 \\
\hline $\mathrm{BaO}$ & 0.1 & n.d. & n.d. & 0.08 & n.d. & 0.1 \\
\hline $\mathrm{CaO}$ & 11.8 & 11.3 & 11.4 & 11.4 & 11.2 & 11.2 \\
\hline $\mathrm{Na}_{2} \mathrm{O}$ & 1.22 & 1.29 & 1.25 & 1.18 & 1.19 & 1.21 \\
\hline $\mathrm{K}_{2} \mathrm{O}$ & 0.96 & 1.07 & 1.04 & 0.85 & 1.16 & 1.02 \\
\hline $\mathrm{F}$ & n.d. & 0.00 & n.d. & 0.00 & 0.00 & 0.00 \\
\hline Total & 98.1 & 97.5 & 97.5 & 98.0 & 97.8 & 98.2 \\
\hline \multicolumn{7}{|c|}{ Stoichiometry based on 23 oxygens } \\
\hline $\mathrm{Si}$ & 6.663 & 6.626 & 6.664 & 6.734 & 6.653 & 6.727 \\
\hline $\mathrm{Ti}$ & 0.135 & 0.204 & 0.102 & 0.107 & 0.192 & 0.172 \\
\hline $\mathrm{Al}$ & 1.738 & 1.776 & 1.775 & 1.728 & 1.831 & 1.714 \\
\hline $\mathrm{Cr}$ & 0.000 & 0.008 & 0.000 & 0.009 & 0.000 & 0.006 \\
\hline $\mathrm{Fe}$ & 2.330 & 2.299 & 2.327 & 2.431 & 2.277 & 2.299 \\
\hline Mn & 0.055 & 0.065 & 0.051 & 0.055 & 0.048 & 0.051 \\
\hline $\mathrm{Mg}$ & 2.473 & 2.431 & 2.544 & 2.358 & 2.399 & 2.448 \\
\hline $\mathrm{Ba}$ & 0.005 & 0.000 & 0.000 & 0.005 & 0.000 & 0.005 \\
\hline $\mathrm{Ca}$ & 1.928 & 1.865 & 1.878 & 1.864 & 1.831 & 1.820 \\
\hline $\mathrm{Na}$ & 0.362 & 0.383 & 0.372 & 0.350 & 0.353 & 0.357 \\
\hline $\mathrm{K}$ & 0.186 & 0.210 & 0.204 & 0.166 & 0.227 & 0.197 \\
\hline $\mathrm{F}$ & 0.000 & 0.000 & 0.000 & 0.000 & 0.000 & 0.000 \\
\hline $\mathrm{Mg} /(\mathrm{Mg}+\mathrm{Fe}+\mathrm{Mn})$ & 0.51 & 0.51 & 0.52 & 0.49 & 0.51 & 0.51 \\
\hline
\end{tabular}




\begin{tabular}{|c|c|c|c|c|c|}
\hline \multicolumn{6}{|c|}{ Residual hornblendes in granitic rocks } \\
\hline & \multicolumn{2}{|c|}{$\begin{array}{c}\text { EE-3A 11600-2 } \\
\text { Granodiorite, core } 3\end{array}$} & \multicolumn{3}{|c|}{$\begin{array}{c}\text { EE-3A 12438-14 } \\
\text { tonalite dike in amphibolite, core } 4\end{array}$} \\
\hline & A-1 & B-1 & A1-7 & A1-8 & A1-9 \\
\hline \multicolumn{6}{|c|}{ Weight Percent } \\
\hline $\mathrm{SiO}_{2}$ & 42.3 & 43.5 & 43.5 & 43.6 & 44.0 \\
\hline $\mathrm{TiO}_{2}$ & 1.2 & 0.56 & 0.76 & 0.69 & 0.62 \\
\hline $\mathrm{Al}_{2} \mathrm{O}_{3}$ & 10.8 & 9.7 & 9.2 & 9.4 & 9.5 \\
\hline $\mathrm{Cr}_{2} \mathrm{O}_{3}$ & n.d. & n.d. & n.d. & 0.00 & 0.05 \\
\hline $\mathrm{FeO}$ & 18.3 & 18.3 & 19.1 & 19.1 & 19.0 \\
\hline $\mathrm{MnO}$ & 1.07 & 0.83 & 0.56 & 0.54 & 0.59 \\
\hline $\mathrm{MgO}$ & 9.2 & 9.3 & 10.1 & 10.0 & 9.9 \\
\hline $\mathrm{BaO}$ & 0.2 & 0.1 & 0.2 & 0.1 & 0.1 \\
\hline $\mathrm{CaO}$ & 11.5 & 11.8 & 11.7 & 11.7 & 11.5 \\
\hline $\mathrm{Na}_{2} \mathrm{O}$ & 1.33 & 1.19 & 1.25 & 1.27 & 1.38 \\
\hline $\mathrm{K}_{2} \mathrm{O}$ & 1.21 & 0.88 & 0.84 & 0.81 & 0.81 \\
\hline $\mathrm{F}$ & n.d. & n.d. & 0.00 & 0.00 & 0.00 \\
\hline Total & 97.1 & 96.7 & 97.2 & 97.2 & 97.5 \\
\hline \multicolumn{6}{|c|}{ Stoichiometry based on 23 oxygens } \\
\hline $\mathrm{Si}$ & 6.581 & 6.782 & 6.731 & 6.740 & 6.782 \\
\hline $\mathrm{Ti}$ & 0.143 & 0.065 & 0.089 & 0.080 & 0.072 \\
\hline $\mathrm{Al}$ & 1.981 & 1.777 & 1.685 & 1.712 & 1.716 \\
\hline $\mathrm{Cr}$ & 0.000 & 0.000 & 0.000 & 0.000 & 0.006 \\
\hline $\mathrm{Fe}$ & 2.381 & 2.387 & 2.470 & 2.471 & 2.443 \\
\hline Mn & 0.142 & 0.109 & 0.073 & 0.070 & 0.077 \\
\hline $\mathrm{Mg}$ & 2.131 & 2.164 & 2.330 & 2.299 & 2.280 \\
\hline $\mathrm{Ba}$ & 0.011 & 0.007 & 0.012 & 0.008 & 0.003 \\
\hline $\mathrm{Ca}$ & 1.912 & 1.966 & 1.947 & 1.945 & 1.905 \\
\hline $\mathrm{Na}$ & 0.402 & 0.358 & 0.374 & 0.381 & 0.413 \\
\hline $\mathrm{K}$ & 0.240 & 0.175 & 0.166 & 0.160 & 0.159 \\
\hline $\mathrm{F}$ & 0.000 & 0.000 & 0.000 & 0.000 & 0.000 \\
\hline $\mathrm{Mg} /(\mathrm{Mg}+\mathrm{Fe}+\mathrm{Mn})$ & 0.46 & 0.46 & 0.48 & 0.48 & 0.48 \\
\hline
\end{tabular}




\begin{tabular}{|c|c|c|c|c|c|c|c|}
\hline \multicolumn{8}{|c|}{ EE-2 12853-2 hornblende (monzogranite, core 2) } \\
\hline & $\mathrm{X}-34$ & $\mathrm{X}-35$ & $\mathrm{X}-36$ & $\mathrm{X}-37$ & $\mathrm{X}-38$ & $\mathbf{X - 3 9}$ & $\mathrm{X}-40$ \\
\hline \multicolumn{8}{|c|}{ Weight Percent } \\
\hline $\mathrm{SiO}_{2}$ & 43.9 & 44.1 & 44.1 & 43.7 & 43.8 & 43.8 & 43.6 \\
\hline $\mathrm{TiO}_{2}$ & 0.77 & 0.97 & 0.78 & 1.23 & 0.70 & 0.65 & 0.69 \\
\hline $\mathrm{Al}_{2} \mathrm{O}_{3}$ & 9.6 & 9.2 & 9.5 & 9.2 & 9.6 & 9.4 & 9.9 \\
\hline $\mathrm{Cr}_{2} \mathrm{O}_{3}$ & 0.00 & n.d. & n.d. & 0.00 & 0.00 & 0.00 & n.d. \\
\hline $\mathrm{FeO}$ & 19.7 & 19.0 & 19.5 & 19.1 & 19.7 & 19.7 & 20.3 \\
\hline $\mathrm{MnO}$ & 0.78 & 0.77 & 0.81 & 0.81 & 0.81 & 0.78 & 0.87 \\
\hline $\mathrm{MgO}$ & 9.3 & 9.7 & 9.6 & 9.7 & 9.3 & 9.8 & 9.0 \\
\hline $\mathrm{BaO}$ & 0.00 & n.d. & 0.00 & n.d. & 0.00 & 0.00 & 0.00 \\
\hline $\mathrm{CaO}$ & 12.1 & 12.1 & 11.8 & 12.0 & 11.8 & 12.3 & 11.9 \\
\hline $\mathrm{Na}_{2} \mathrm{O}$ & 1.28 & 1.38 & 1.20 & 1.31 & 1.22 & 1.22 & 1.37 \\
\hline $\mathrm{K}_{2} \mathrm{O}$ & 1.08 & 1.15 & 1.02 & 1.15 & 1.08 & 1.02 & 1.05 \\
\hline $\mathrm{F}$ & 0.00 & 0.00 & 0.00 & 0.00 & 0.00 & 0.00 & 0.00 \\
\hline Total & 98.5 & 98.4 & 98.3 & 98.2 & 98.0 & 98.7 & 98.7 \\
\hline \multicolumn{8}{|c|}{ Stoichiometry based on 23 oxygens } \\
\hline $\mathrm{Si}$ & 6.738 & 6.767 & 6.756 & 6.724 & 6.748 & 6.715 & 6.697 \\
\hline $\mathrm{Ti}$ & 0.088 & 0.112 & 0.089 & 0.142 & 0.081 & 0.075 & 0.080 \\
\hline $\mathrm{Al}$ & 1.736 & 1.659 & 1.721 & 1.663 & 1.746 & 1.696 & 1.798 \\
\hline $\mathrm{Cr}$ & 0.000 & 0.000 & 0.000 & 0.000 & 0.000 & 0.000 & 0.000 \\
\hline $\mathrm{Fe}$ & 2.532 & 2.436 & 2.497 & 2.462 & 2.534 & 2.525 & 2.603 \\
\hline $\mathrm{Mn}$ & 0.101 & 0.100 & 0.105 & 0.105 & 0.106 & 0.101 & 0.113 \\
\hline $\mathrm{Mg}$ & 2.124 & 2.227 & 2.180 & 2.219 & 2.142 & 2.235 & 2.069 \\
\hline $\mathrm{Ba}$ & 0.000 & 0.000 & 0.000 & 0.000 & 0.000 & 0.000 & 0.000 \\
\hline $\mathrm{Ca}$ & 1.986 & 1.984 & 1.942 & 1.978 & 1.942 & 2.014 & 1.959 \\
\hline $\mathrm{Na}$ & 0.382 & 0.410 & 0.356 & 0.391 & 0.364 & 0.363 & 0.408 \\
\hline $\mathrm{K}$ & 0.211 & 0.225 & 0.200 & 0.226 & 0.213 & 0.199 & 0.206 \\
\hline $\mathrm{F}$ & 0.000 & 0.000 & 0.000 & 0.000 & 0.000 & 0.000 & 0.000 \\
\hline $\mathrm{Mg} /(\mathrm{Mg}+\mathrm{Fe}+\mathrm{Mn})$ & 0.45 & 0.47 & 0.46 & 0.46 & 0.45 & 0.46 & 0.43 \\
\hline
\end{tabular}




\begin{tabular}{|c|c|c|c|c|}
\hline \multicolumn{5}{|c|}{ EE-2 12853-2 hornblende (monzogranite, core 2) continued } \\
\hline & $\mathrm{X}-41$ & $\mathrm{X}-42$ & $\mathrm{X}-43$ & $X-44$ \\
\hline \multicolumn{5}{|c|}{ Weight Percent } \\
\hline $\mathrm{SiO}_{2}$ & 44.5 & 44.3 & 44.0 & 42.8 \\
\hline $\mathrm{TiO}_{2}$ & 1.11 & 1.16 & 0.56 & 0.76 \\
\hline $\mathrm{Al}_{2} \mathrm{O}_{3}$ & 9.4 & 9.1 & 9.6 & 10.1 \\
\hline $\mathrm{Cr}_{2} \mathrm{O}_{3}$ & n.d. & n.d. & 0.00 & n.d. \\
\hline $\mathrm{FeO}$ & 19.1 & 19.2 & 19.6 & 20.1 \\
\hline $\mathrm{MnO}$ & 0.89 & 1.03 & 0.69 & 0.83 \\
\hline $\mathrm{MgO}$ & 9.8 & 9.8 & 9.4 & 9.0 \\
\hline $\mathrm{BaO}$ & n.d. & 0.00 & n.d. & n.d. \\
\hline $\mathrm{CaO}$ & 12.2 & 12.0 & 12.3 & 12.4 \\
\hline $\mathrm{Na}_{2} \mathrm{O}$ & 1.45 & 1.33 & 1.22 & 1.20 \\
\hline $\mathrm{K}_{2} \mathrm{O}$ & 1.14 & 1.17 & 1.08 & 1.10 \\
\hline $\mathrm{F}$ & 0.00 & 0.00 & 0.00 & 0.00 \\
\hline Total & 99.6 & 99.1 & 98.5 & 98.3 \\
\hline \multicolumn{5}{|c|}{ Stoichiometry based on 23 oxygens } \\
\hline $\mathrm{Si}$ & 6.749 & 6.755 & 6.745 & 6.613 \\
\hline $\mathrm{Ti}$ & 0.127 & 0.132 & 0.064 & 0.089 \\
\hline $\mathrm{Al}$ & 1.672 & 1.642 & 1.734 & 1.832 \\
\hline $\mathrm{Cr}$ & 0.000 & 0.000 & 0.000 & 0.000 \\
\hline $\mathrm{Fe}$ & 2.423 & 2.449 & 2.513 & 2.597 \\
\hline $\mathrm{Mn}$ & 0.114 & 0.134 & 0.090 & 0.109 \\
\hline $\mathrm{Mg}$ & 2.210 & 2.220 & 2.151 & 2.074 \\
\hline $\mathrm{Ba}$ & 0.000 & 0.000 & 0.000 & 0.000 \\
\hline $\mathrm{Ca}$ & 1.984 & 1.958 & 2.024 & 2.061 \\
\hline $\mathrm{Na}$ & 0.427 & 0.393 & 0.361 & 0.359 \\
\hline K & 0.221 & 0.227 & 0.212 & 0.216 \\
\hline $\mathrm{F}$ & 0.000 & 0.000 & 0.000 & 0.000 \\
\hline $\mathrm{Mg} /(\mathrm{Mg}+\mathrm{Fe}+\mathrm{Mn})$ & 0.47 & 0.46 & 0.45 & 0.43 \\
\hline
\end{tabular}




\begin{tabular}{|c|c|c|c|c|}
\hline \multicolumn{5}{|c|}{ EE-3A 9450-5C-C hornblende (amphibolite, core 1) } \\
\hline & $\mathrm{X}-\mathbf{2}$ & $\mathrm{X}-\mathbf{3}$ & $X-4$ & $\mathrm{X}-5$ \\
\hline \multicolumn{5}{|c|}{ Weight Percent } \\
\hline $\mathrm{SiO}_{2}$ & 42.8 & 42.3 & 42.4 & 42.8 \\
\hline $\mathrm{TiO}_{2}$ & 1.8 & 2.0 & 2.0 & 1.9 \\
\hline $\mathrm{Al}_{2} \mathrm{O}_{3}$ & 10.2 & 10.4 & 10.7 & 9.9 \\
\hline $\mathrm{Cr}_{2} \mathrm{O}_{3}$ & 0.12 & 0.15 & 0.17 & 0.10 \\
\hline $\mathrm{FeO}$ & 17.5 & 17.8 & 17.4 & 17.4 \\
\hline $\mathrm{MnO}$ & 0.52 & 0.53 & 0.55 & 0.45 \\
\hline $\mathrm{MgO}$ & 10.4 & 9.9 & 10.2 & 10.3 \\
\hline $\mathrm{BaO}$ & 0.4 & 0.4 & 0.2 & 0.2 \\
\hline $\mathrm{CaO}$ & 11.4 & 11.3 & 11.4 & 11.4 \\
\hline $\mathrm{Na}_{2} \mathrm{O}$ & 1.50 & 1.54 & 1.54 & 1.51 \\
\hline $\mathrm{K}_{2} \mathrm{O}$ & 1.27 & 1.27 & 1.25 & 1.23 \\
\hline $\mathrm{F}$ & 1.0 & 1.2 & n.d. & 1.6 \\
\hline Total & 98.9 & 98.8 & 97.8 & 98.8 \\
\hline \multicolumn{5}{|c|}{ Stoichiometry based on 23 oxygens } \\
\hline $\mathrm{Si}$ & 6.594 & 6.540 & 6.536 & 6.621 \\
\hline $\mathrm{Ti}$ & 0.203 & 0.238 & 0.227 & 0.218 \\
\hline $\mathrm{Al}$ & 1.843 & 1.899 & 1.936 & 1.813 \\
\hline $\mathrm{Cr}$ & 0.015 & 0.019 & 0.021 & 0.012 \\
\hline $\mathrm{Fe}$ & 2.259 & 2.303 & 2.238 & 2.254 \\
\hline $\mathrm{Mn}$ & 0.068 & 0.069 & 0.072 & 0.059 \\
\hline $\mathrm{Mg}$ & 2.395 & 2.291 & 2.337 & 2.373 \\
\hline $\mathrm{Ba}$ & 0.021 & 0.025 & 0.014 & 0.015 \\
\hline $\mathrm{Ca}$ & 1.878 & 1.880 & 1.877 & 1.884 \\
\hline $\mathrm{Na}$ & 0.447 & 0.461 & 0.460 & 0.453 \\
\hline $\mathrm{K}$ & 0.249 & 0.251 & 0.246 & 0.242 \\
\hline $\mathrm{F}$ & 0.496 & 0.587 & 0.000 & 0.762 \\
\hline $\mathrm{Mg} /(\mathrm{Mg}+\mathrm{Fe}+\mathrm{Mn})$ & 0.51 & 0.49 & 0.50 & 0.51 \\
\hline
\end{tabular}




\begin{tabular}{|c|c|c|c|c|c|c|}
\hline \multicolumn{7}{|c|}{ EE-3A 12438-51C hornblende (amphibolite, core 4) } \\
\hline & Amph 1 & Amph 2 & Amph 3 & Amph 4 & C-1 & C-4 \\
\hline \multicolumn{7}{|c|}{ Weight Percent } \\
\hline $\mathrm{SiO}_{2}$ & 43.6 & 43.8 & 43.8 & 43.8 & 45.4 & 45.0 \\
\hline $\mathrm{TiO}_{2}$ & 1.71 & 1.63 & 1.66 & 1.69 & 0.31 & 1.24 \\
\hline $\mathrm{Al}_{2} \mathrm{O}_{3}$ & 10.7 & 10.6 & 10.6 & 10.5 & 9.3 & 9.5 \\
\hline $\mathrm{Cr}_{2} \mathrm{O}_{3}$ & 0.09 & n.d. & n.d. & 0.05 & n.d. & n.d. \\
\hline $\mathrm{FeO}$ & 18.0 & 17.8 & 18.1 & 18.2 & 17.6 & 16.8 \\
\hline $\mathrm{MnO}$ & 0.36 & 0.37 & 0.31 & 0.37 & 0.34 & 0.42 \\
\hline $\mathrm{MgO}$ & 10.2 & 10.2 & 10.3 & 10.2 & 10.9 & 11.3 \\
\hline $\mathrm{BaO}$ & 0.21 & 0.16 & 0.17 & 0.13 & n.d. & n.d. \\
\hline $\mathrm{CaO}$ & 11.8 & 12.1 & 12.1 & 11.9 & 11.8 & 11.7 \\
\hline $\mathrm{Na}_{2} \mathrm{O}$ & 1.36 & 1.42 & 1.34 & 1.35 & 1.20 & 1.25 \\
\hline $\mathrm{K}_{2} \mathrm{O}$ & 1.16 & 1.11 & 1.11 & 1.13 & 0.31 & 0.68 \\
\hline $\mathrm{F}$ & n.d. & n.d. & n.d. & n.d. & n.d. & n.d. \\
\hline Total & 99.2 & 99.2 & 99.5 & 99.3 & 97.2 & 97.9 \\
\hline \multicolumn{7}{|c|}{ Stoichiometry based on 23 oxygens } \\
\hline $\mathrm{Si}$ & 6.588 & 6.617 & 6.600 & 6.612 & 6.882 & 6.795 \\
\hline $\mathrm{Ti}$ & 0.194 & 0.185 & 0.188 & 0.192 & 0.035 & 0.140 \\
\hline $\mathrm{Al}$ & 1.910 & 1.892 & 1.881 & 1.869 & 1.671 & 1.683 \\
\hline $\mathrm{Cr}$ & 0.011 & 0.000 & 0.000 & 0.006 & 0.000 & 0.000 \\
\hline $\mathrm{Fe}$ & 2.277 & 2.244 & 2.284 & 2.303 & 2.228 & 2.121 \\
\hline $\mathrm{Mn}$ & 0.045 & 0.047 & 0.040 & 0.048 & 0.044 & 0.054 \\
\hline $\mathrm{Mg}$ & 2.305 & 2.299 & 2.314 & $2 .-287$ & 2.463 & 2.542 \\
\hline $\mathrm{Ba}$ & 0.013 & 0.010 & 0.010 & 0.008 & 0.000 & 0.000 \\
\hline $\mathrm{Ca}$ & 1.914 & 1.956 & 1.947 & 1.933 & 1.925 & 1.885 \\
\hline $\mathrm{Na}$ & 0.399 & 0.417 & 0.391 & 0.394 & 0.353 & 0.361 \\
\hline $\mathrm{K}$ & 0.224 & 0.214 & 0.214 & 0.218 & 0.060 & 0.132 \\
\hline $\mathrm{F}$ & 0.000 & 0.000 & 0.000 & 0.000 & 0.000 & 0.000 \\
\hline $\mathrm{Mg} /(\mathrm{Mg}+\mathrm{Fe}+\mathrm{Mn})$ & 0.50 & 0.50 & 0.50 & 0.49 & 0.52 & 0.54 \\
\hline
\end{tabular}




\begin{tabular}{|c|c|c|c|c|}
\hline & \multirow{2}{*}{\multicolumn{2}{|c|}{$\begin{array}{c}\text { EE-3A 12438-51C } \\
\text { amphiboles (amphibolite, core 4) } \\
\text { actinolite }\end{array}$}} & \multicolumn{2}{|c|}{$\begin{array}{c}\text { EE-2 } 11100 \text { hornblende } \\
\text { (junk basket, amphibolite) }\end{array}$} \\
\hline & & & \multirow[b]{2}{*}{ A-5 } & \multirow[b]{2}{*}{ A-6 } \\
\hline & $\mathrm{C}-2$ & C-3 & & \\
\hline \multicolumn{5}{|c|}{ Weight Percent } \\
\hline $\mathrm{SiO}_{2}$ & 53.1 & 52.9 & 40.8 & 41.0 \\
\hline $\mathrm{TiO}_{2}$ & 0.02 & 0.11 & 1.82 & 1.56 \\
\hline $\mathrm{Al}_{2} \mathrm{O}_{3}$ & 2.5 & 2.6 & 13.0 & 12.7 \\
\hline $\mathrm{Cr}_{2} \mathrm{O}_{3}$ & n.d. & n.d. & 0.06 & 0.12 \\
\hline $\mathrm{FeO}$ & 12.0 & 12.2 & 12.9 & 12.7 \\
\hline $\mathrm{MnO}$ & 0.30 & 0.28 & 0.26 & 0.26 \\
\hline $\mathrm{MgO}$ & 16.1 & 16.0 & 12.75 & 12.81 \\
\hline $\mathrm{BaO}$ & n.d. & n.d. & 0.07 & 0.16 \\
\hline $\mathrm{CaO}$ & 12.3 & 12.3 & 11.9 & 12.2 \\
\hline $\mathrm{Na}_{2} \mathrm{O}$ & 0.34 & 0.40 & 1.53 & 1.60 \\
\hline $\mathrm{K}_{2} \mathrm{O}$ & n.d. & n.d. & 1.95 & 1.72 \\
\hline $\mathrm{F}$ & n.d. & n.d. & n.d. & 1.5 \\
\hline $\mathrm{Cl}$ & n.a. & n.a. & n.a. & n.a. \\
\hline Total & 96.7 & 96.8 & 97.0 & 98.3 \\
\hline \multicolumn{5}{|c|}{ Stoichiometry based on 23 oxygens } \\
\hline $\mathrm{Si}$ & 7.73 & 7.70 & 6.25 & 6.29 \\
\hline $\mathrm{Ti}$ & 0.00 & 0.01 & 0.21 & 0.18 \\
\hline $\mathrm{Al}$ & 0.42 & 0.45 & 2.34 & 2.29 \\
\hline $\mathrm{Cr}$ & 0.00 & 0.00 & 0.01 & 0.02 \\
\hline $\mathrm{Fe}$ & 1.46 & 1.48 & 1.65 & 1.63 \\
\hline $\mathrm{Mn}$ & 0.04 & 0.03 & 0.03 & 0.03 \\
\hline $\mathrm{Mg}$ & 3.50 & 3.47 & 2.91 & 2.93 \\
\hline $\mathrm{Ba}$ & 0.00 & 0.00 & 0.00 & 0.01 \\
\hline $\mathrm{Ca}$ & 1.91 & 1.92 & 1.96 & 2.01 \\
\hline $\mathrm{Na}$ & 0.10 & 0.11 & 0.46 & 0.48 \\
\hline K & 0.00 & 0.00 & 0.38 & 0.34 \\
\hline $\mathrm{F}$ & 0.00 & 0.00 & 0.00 & 0.75 \\
\hline $\mathrm{Mg} /(\mathrm{Mg}+\mathrm{Fe}+\mathrm{Mn})$ & 0.70 & 0.70 & 0.63 & 0.64 \\
\hline
\end{tabular}




\begin{tabular}{|c|c|c|c|c|}
\hline \multicolumn{5}{|c|}{ EE-2 12849-3 hornblende (biotite-plagioclase rock and monzogranite, core 2) } \\
\hline & \multicolumn{3}{|c|}{ biotite-plagioclase rock } & \multirow{2}{*}{$\begin{array}{c}\text { monzogranite } \\
X-1\end{array}$} \\
\hline & E-4 & E-5 & E-6 & \\
\hline \multicolumn{5}{|c|}{ Weight Percent } \\
\hline $\mathrm{SiO}_{2}$ & 42.7 & 43.3 & 43.2 & 43.9 \\
\hline $\mathrm{TiO}_{2}$ & 0.48 & 0.68 & 0.46 & 0.79 \\
\hline $\mathrm{Al}_{2} \mathrm{O}_{3}$ & 10.1 & 9.3 & 9.8 & 9.6 \\
\hline $\mathrm{Cr}_{2} \mathrm{O}_{3}$ & 0.00 & 0.00 & 0.00 & n.d. \\
\hline $\mathrm{FeO}$ & 20.5 & 20.9 & 20.0 & 20.8 \\
\hline $\mathrm{MnO}$ & 0.66 & 0.71 & 0.67 & 0.75 \\
\hline $\mathrm{MgO}$ & 9.1 & 9.2 & 9.3 & 9.3 \\
\hline $\mathrm{BaO}$ & 0.00 & 0.00 & 0.00 & n.d. \\
\hline $\mathrm{CaO}$ & 11.5 & 11.4 & 11.3 & 11.4 \\
\hline $\mathrm{Na}_{2} \mathrm{O}$ & 1.35 & 1.46 & 1.42 & 1.47 \\
\hline $\mathrm{K}_{2} \mathrm{O}$ & 1.01 & 0.87 & 0.93 & 0.99 \\
\hline $\mathrm{F}$ & n.d. & n.d. & n.d. & n.d. \\
\hline Total & 97.4 & 97.8 & 97.1 & 99.0 \\
\hline \multicolumn{5}{|c|}{ Stoichiometry based on 23 oxygens } \\
\hline $\mathrm{Si}$ & 6.65 & 6.72 & 6.73 & 6.73 \\
\hline $\mathrm{Ti}$ & 0.06 & 0.08 & 0.05 & 0.09 \\
\hline $\mathrm{Al}$ & 1.86 & 1.70 & 1.79 & 1.73 \\
\hline $\mathrm{Cr}$ & 0.00 & 0.00 & 0.00 & 0.00 \\
\hline $\mathrm{Fe}$ & 2.67 & 2.72 & 2.61 & 2.66 \\
\hline $\mathrm{Mn}$ & 0.09 & 0.09 & 0.09 & 0.10 \\
\hline $\mathrm{Mg}$ & 2.12 & 2.14 & 2.15 & 2.12 \\
\hline $\mathrm{Sa}$ & 0.00 & 0.00 & 0.00 & 0.00 \\
\hline $\mathrm{Ca}$ & 1.92 & 1.89 & 1.89 & 1.87 \\
\hline $\mathrm{Na}$ & 0.41 & 0.44 & 0.43 & 0.44 \\
\hline K & 0.20 & 0.17 & 0.18 & 0.19 \\
\hline $\mathrm{F}$ & 0.00 & 0.00 & 0.00 & 0.00 \\
\hline $\mathrm{Mg} /(\mathrm{Mg}+\mathrm{Fe}+\mathrm{Mn})$ & 0.43 & 0.43 & 0.44 & 0.43 \\
\hline
\end{tabular}




\begin{tabular}{|c|c|c|c|c|c|c|c|}
\hline \multicolumn{8}{|c|}{ EE-2 12851-4A hornblende (biotite-plagioclase rock, core 2) } \\
\hline & \multicolumn{7}{|c|}{ mafic clot } \\
\hline & B1-1 & B1-2 & B1-3 & B2-2 & B2-3 & C-1 & C-3 \\
\hline \multicolumn{8}{|c|}{ Weight Percent } \\
\hline $\mathrm{SiO}_{2}$ & 44.8 & 44.1 & 46.6 & 43.4 & 45.2 & 45.4 & 49.7 \\
\hline $\mathrm{TiO}_{2}$ & 0.65 & 0.32 & 0.36 & 0.50 & 0.30 & 0.53 & 0.35 \\
\hline $\mathrm{Al}_{2} \mathrm{O}_{3}$ & 9.6 & 10.2 & 7.8 & 10.5 & 9.3 & 8.6 & 5.8 \\
\hline $\mathrm{Cr}_{2} \mathrm{O}_{3}$ & 0.07 & 0.08 & 0.08 & 0.10 & 0.06 & 0.17 & 0.23 \\
\hline $\mathrm{FeO}$ & 20.2 & 20.9 & 18.7 & 20.9 & 19.6 & 19.4 & 17.0 \\
\hline $\mathrm{MnO}$ & 0.66 & 0.58 & 0.61 & 0.70 & 0.67 & 0.74 & 0.62 \\
\hline $\mathrm{MgO}$ & 9.6 & 9.3 & 10.6 & 8.6 & 9.9 & 10.2 & 12.5 \\
\hline $\mathrm{BaO}$ & n.d. & n.d. & 0.00 & 0.00 & n.d. & n.d. & 0.00 \\
\hline $\mathrm{CaO}$ & 11.1 & 11.5 & 12.1 & 11.2 & 11.5 & 11.3 & 11.5 \\
\hline $\mathrm{Na}_{2} \mathrm{O}$ & 1.10 & 1.20 & 1.01 & 1.12 & 1.08 & 1.05 & 0.78 \\
\hline $\mathrm{K}_{2} \mathrm{O}$ & 0.94 & 0.99 & 0.70 & 1.03 & 0.81 & 0.79 & 0.41 \\
\hline $\mathrm{F}$ & 0.00 & 0.00 & n.d. & 0.00 & 0.00 & 0.00 & n.d. \\
\hline Total & 98.7 & 99.2 & 98.6 & 98.1 & 98.4 & 98.2 & 98.9 \\
\hline \multicolumn{8}{|c|}{ Stoichiometry based on 23 oxygens } \\
\hline $\mathrm{Si}$ & 6.82 & 6.72 & 7.02 & 6.70 & 6.87 & 6.91 & 7.32 \\
\hline $\mathrm{Ti}$ & 0.07 & 0.04 & 0.04 & 0.06 & 0.03 & 0.06 & 0.04 \\
\hline $\mathrm{Al}$ & 1.71 & 1.82 & 1.39 & 1.90 & 1.66 & 1.54 & 1.01 \\
\hline $\mathrm{Cr}$ & 0.01 & 0.01 & 0.01 & 0.01 & 0.01 & 0.02 & 0.03 \\
\hline $\mathrm{Fe}$ & 2.57 & 2.67 & 2.36 & 2.70 & 2.49 & 2.46 & 2.10 \\
\hline $\mathrm{Mn}$ & 0.08 & 0.08 & 0.08 & 0.09 & 0.09 & 0.10 & 0.08 \\
\hline $\mathrm{Mg}$ & 2.17 & 2.11 & 2.39 & 1.97 & 2.25 & 2.32 & 2.74 \\
\hline $\mathrm{Ba}$ & 0.00 & 0.00 & 0.00 & 0.00 & 0.00 & 0.00 & 0.00 \\
\hline $\mathrm{Ca}$ & 1.81 & 1.87 & 1.95 & 1.85 & 1.87 & 1.84 & 1.81 \\
\hline $\mathrm{Na}$ & 0.33 & 0.36 & 0.30 & 0.34 & 0.32 & 0.31 & 0.22 \\
\hline $\mathrm{K}$ & 0.18 & 0.19 & 0.14 & 0.20 & 0.16 & 0.15 & 0.08 \\
\hline $\mathrm{F}$ & 0.00 & 0.00 & 0.00 & 0.00 & 0.00 & 0.00 & 0.00 \\
\hline $\mathrm{Mg} /(\mathrm{Mg}+\mathrm{Fe}+\mathrm{Mn})$ & 0.45 & 0.44 & 0.50 & 0.41 & 0.47 & 0.48 & 0.56 \\
\hline
\end{tabular}




\begin{tabular}{|c|c|c|c|c|c|}
\hline \multicolumn{6}{|c|}{ EE-2 12851-4A hornblende (biotite-plagioclase rock, core 2) continued } \\
\hline & \multicolumn{2}{|c|}{ mafic clot } & $\begin{array}{l}\text { residual bleb in } \\
\text { plagioclase } \\
\text { within mafic clot }\end{array}$ & \multicolumn{2}{|c|}{ groundmass } \\
\hline & C-4 & C-5 & B2-1 & C-2 & C-6 \\
\hline \multicolumn{6}{|c|}{ Weight Percent } \\
\hline $\mathrm{SiO}_{2}$ & 43.7 & 46.3 & 47.4 & 43.6 & 44.2 \\
\hline $\mathrm{TiO}_{2}$ & 0.82 & 0.55 & 0.48 & 0.62 & 0.64 \\
\hline $\mathrm{Al}_{2} \mathrm{O}_{3}$ & 10.0 & 8.3 & 8.7 & 10.4 & 10.1 \\
\hline $\mathrm{Cr}_{2} \mathrm{O}_{3}$ & 0.09 & 0.09 & 0.08 & 0.06 & n.d. \\
\hline $\mathrm{FeO}$ & 20.2 & 19.1 & 18.5 & 21.1 & 20.4 \\
\hline $\mathrm{MnO}$ & 0.60 & 0.54 & 0.57 & 0.63 & 0.63 \\
\hline $\mathrm{MgO}$ & 9.7 & 10.9 & 9.6 & 9.1 & 9.4 \\
\hline $\mathrm{BaO}$ & n.d. & n.d. & n.d. & n.d. & 0.00 \\
\hline $\mathrm{CaO}$ & 11.3 & 11.3 & 11.3 & 11.4 & 11.4 \\
\hline $\mathrm{Na}_{2} \mathrm{O}$ & 1.42 & 1.01 & 1.10 & 1.24 & 1.08 \\
\hline $\mathrm{K}_{2} \mathrm{O}$ & 1.06 & 0.73 & 0.78 & 1.08 & 0.98 \\
\hline $\mathrm{F}$ & 0.00 & n.d. & n.d. & 0.00 & n.d. \\
\hline Total & 98.9 & 98.8 & 98.5 & 99.2 & 98.8 \\
\hline \multicolumn{6}{|c|}{ Stoichiometry based on 23 oxygens } \\
\hline $\mathrm{Si}$ & 6.69 & 6.97 & 7.11 & 6.67 & 6.73 \\
\hline $\mathrm{Ti}$ & 0.10 & 0.06 & 0.05 & 0.07 & 0.07 \\
\hline $\mathrm{Al}$ & 1.80 & 1.46 & 1.54 & 1.87 & 1.81 \\
\hline $\mathrm{Cr}$ & 0.01 & 0.01 & 0.01 & 0.01 & 0.00 \\
\hline $\mathrm{Fe}$ & 2.59 & 2.41 & 2.31 & 2.69 & 2.61 \\
\hline $\mathrm{Mn}$ & 0.08 & 0.07 & 0.07 & 0.08 & 0.08 \\
\hline $\mathrm{Mg}$ & 2.21 & 2.43 & 2.15 & 2.07 & 2.12 \\
\hline $\mathrm{Ba}$ & 0.00 & 0.00 & 0.00 & 0.00 & 0.00 \\
\hline $\mathrm{Ca}$ & 1.85 & 1.82 & 1.81 & 1.87 & 1.86 \\
\hline $\mathrm{Na}$ & 0.42 & 0.29 & 0.32 & 0.37 & 0.32 \\
\hline K & 0.21 & 0.14 & 0.14 & 0.21 & 0.19 \\
\hline $\mathrm{F}$ & 0.00 & 0.00 & 0.00 & 0.00 & 0.00 \\
\hline $\mathrm{Mg} /(\mathrm{Mg}+\mathrm{Fe}+\mathrm{Mn})$ & 0.45 & 0.50 & 0.47 & 0.43 & 0.44 \\
\hline
\end{tabular}




\begin{tabular}{|c|c|c|c|c|}
\hline \multicolumn{5}{|c|}{ EE-2 12851-4A hornblende (biotite-plagioclase rock. core 2) continued } \\
\hline & \multicolumn{4}{|c|}{ groundmass } \\
\hline & C-7 & C-8 & C-9 & C-10 \\
\hline \multicolumn{5}{|c|}{ Weight Percent } \\
\hline $\mathrm{SiO}_{2}$ & 43.6 & 44.4 & 43.4 & 43.6 \\
\hline $\mathrm{TiO}_{2}$ & 0.37 & 0.59 & 0.64 & 0.34 \\
\hline $\mathrm{Al}_{2} \mathrm{O}_{3}$ & 10.7 & 9.7 & 10.2 & 10.8 \\
\hline $\mathrm{Cr}_{2} \mathrm{O}_{3}$ & n.d. & 0.06 & 0.07 & 0.07 \\
\hline $\mathrm{FeO}$ & 20.9 & 20.1 & 20.3 & 20.9 \\
\hline $\mathrm{MnO}$ & 0.56 & 0.62 & 0.63 & 0.62 \\
\hline $\mathrm{MgO}$ & 9.2 & 9.4 & 9.3 & 8.7 \\
\hline $\mathrm{BaO}$ & 0.00 & n.d. & n.d. & 0.00 \\
\hline $\mathrm{CaO}$ & 11.4 & 10.9 & 11.2 & 11.1 \\
\hline $\mathrm{Na}_{2} \mathrm{O}$ & 1.32 & 1.11 & 1.24 & 1.15 \\
\hline $\mathrm{K}_{2} \mathrm{O}$ & 1.04 & 0.95 & 1.01 & 1.02 \\
\hline $\mathrm{F}$ & 0.00 & 0.00 & 0.00 & n.d. \\
\hline Total & 99.1 & 97.8 & 98.0 & 98.3 \\
\hline \multicolumn{5}{|c|}{ Stoichiometry based on 23 oxygens } \\
\hline $\mathrm{Si}$ & 6.66 & 6.81 & 6.68 & 6.70 \\
\hline $\mathrm{Ti}$ & 0.04 & 0.07 & 0.07 & 0.04 \\
\hline $\mathrm{Al}$ & 1.93 & 1.75 & 1.86 & 1.96 \\
\hline $\mathrm{Cr}$ & 0.00 & 0.01 & 0.01 & 0.01 \\
\hline $\mathrm{Fe}$ & 2.67 & 2.57 & 2.62 & 2.69 \\
\hline $\mathrm{Mn}$ & 0.07 & 0.08 & 0.08 & 0.08 \\
\hline $\mathrm{Mg}$ & 2.09 & 2.16 & 2.13 & 1.98 \\
\hline $\mathrm{Ba}$ & 0.00 & 0.00 & 0.00 & 0.00 \\
\hline $\mathrm{Ca}$ & 1.87 & 1.79 & 1.85 & 1.83 \\
\hline $\mathrm{Na}$ & 0.39 & 0.33 & 0.37 & 0.34 \\
\hline $\mathrm{K}$ & 0.20 & 0.19 & 0.20 & 0.20 \\
\hline $\mathrm{F}$ & 0.00 & 0.00 & 0.00 & 0.00 \\
\hline $\mathrm{Mg} /(\mathrm{Mg}+\mathrm{Fe}+\mathrm{Mn})$ & 0.43 & 0.45 & 0.44 & 0.42 \\
\hline
\end{tabular}




\begin{tabular}{|c|c|c|c|c|c|c|c|}
\hline \multicolumn{8}{|c|}{ EE-2 12852-1C hornblende (biotite-plagioclase rock, core 2) } \\
\hline & E-10 & E-11 & E-12 & E-14 & E-15 & E-16 & $X-2$ \\
\hline \multicolumn{8}{|c|}{ Weight Percent } \\
\hline $\mathrm{SiO}_{2}$ & 43.4 & 42.7 & 41.9 & 43.6 & 42.6 & 43.4 & 43.8 \\
\hline $\mathrm{TiO}_{2}$ & 0.63 & 0.61 & 0.58 & 0.62 & 0.59 & 0.70 & 0.50 \\
\hline $\mathrm{Al}_{2} \mathrm{O}_{3}$ & 9.9 & 10.4 & 10.2 & 10.0 & 10.5 & 10.2 & 10.1 \\
\hline $\mathrm{Cr}_{2} \mathrm{O}_{3}$ & n.d. & 0.00 & n.d. & 0.05 & 0.06 & 0.06 & 0.06 \\
\hline $\mathrm{FeO}$ & 20.3 & 20.7 & 19.7 & 20.1 & 20.4 & 20.4 & 20.0 \\
\hline $\mathrm{MnO}$ & 0.78 & 0.64 & 0.71 & 0.68 & 0.60 & 0.68 & 0.65 \\
\hline $\mathrm{MgO}$ & 9.4 & 9.1 & 8.8 & 9.3 & 8.9 & 9.0 & 9.4 \\
\hline $\mathrm{BaO}$ & n.d. & 0.19 & 0.00 & n.d. & n.d. & n.d. & n.d. \\
\hline $\mathrm{CaO}$ & 12.1 & 11.6 & 13.1 & 11.6 & 12.3 & 11.5 & 11.7 \\
\hline $\mathrm{Na}_{2} \mathrm{O}$ & 1.22 & 1.23 & 1.15 & 1.30 & 1.28 & 1.36 & 1.15 \\
\hline $\mathrm{K}_{2} \mathrm{O}$ & 1.08 & 1.07 & 1.08 & 1.07 & 1.09 & 1.12 & 1.03 \\
\hline $\mathrm{F}$ & 0.00 & 0.00 & 0.00 & 0.00 & 0.00 & 0.00 & 0.00 \\
\hline Total & 98.8 & 98.2 & 97.2 & 98.3 & 98.3 & 98.4 & 98.4 \\
\hline \multicolumn{8}{|c|}{ Stoichiometry based on 23 oxygens } \\
\hline $\mathrm{Si}$ & 6.661 & 6.601 & 6.559 & 6.706 & 6.588 & 6.681 & 6.709 \\
\hline $\mathrm{Ti}$ & 0.072 & 0.072 & 0.068 & 0.071 & 0.068 & 0.081 & 0.057 \\
\hline $\mathrm{Al}$ & 1.788 & 1.894 & 1.883 & 1.816 & 1.916 & 1.843 & 1.830 \\
\hline $\mathrm{Cr}$ & 0.000 & 0.000 & 0.000 & 0.006 & 0.008 & 0.007 & 0.007 \\
\hline $\mathrm{Fe}$ & 2.606 & 2.681 & 2.575 & 2.585 & 2.634 & 2.634 & 2.560 \\
\hline $\mathrm{Mn}$ & 0.101 & 0.084 & 0.094 & 0.089 & 0.079 & 0.089 & 0.085 \\
\hline $\mathrm{Mg}$ & 2.141 & 2.106 & 2.055 & 2.126 & 2.050 & 2.073 & 2.147 \\
\hline $\mathrm{Ba}$ & 0.000 & 0.011 & 0.000 & 0.000 & 0.000 & 0.000 & 0.000 \\
\hline $\mathrm{Ca}$ & 1.996 & 1.931 & 2.190 & 1.909 & 2.030 & 1.899 & 1.917 \\
\hline $\mathrm{Na}$ & 0.362 & 0.370 & 0.350 & 0.389 & 0.383 & 0.405 & 0.343 \\
\hline $\mathrm{K}$ & 0.212 & 0.211 & 0.216 & 0.210 & 0.215 & 0.220 & 0.201 \\
\hline $\mathrm{F}$ & 0.000 & 0.000 & 0.000 & 0.000 & 0.000 & 0.000 & 0.000 \\
\hline $\mathrm{Mg} /(\mathrm{Mg}+\mathrm{Fe}+\mathrm{Mn})$ & 0.44 & 0.43 & 0.44 & 0.44 & 0.43 & 0.43 & 0.45 \\
\hline
\end{tabular}




\begin{tabular}{|c|c|c|c|c|c|}
\hline \multicolumn{6}{|c|}{ EE-3A 12230-40 and 12270-80B hornblende (bit cuttings, biotite-plagioclase rock) } \\
\hline & \multicolumn{2}{|c|}{ 12230-40 } & \multicolumn{3}{|c|}{ 12270-80B } \\
\hline & A-15 & A-16 & C1-1 & C1-3 & C1-8 \\
\hline \multicolumn{6}{|c|}{ Weight Percent } \\
\hline $\mathrm{SiO}_{2}$ & 41.8 & 42.8 & 43.3 & 43.7 & 42.1 \\
\hline $\mathrm{TiO}_{2}$ & 0.45 & 0.44 & 0.46 & 0.44 & 0.64 \\
\hline $\mathrm{Al}_{2} \mathrm{O}_{3}$ & 10.3 & 10.0 & 10.9 & 10.9 & 10.3 \\
\hline $\mathrm{Cr}_{2} \mathrm{O}_{3}$ & n.d. & n.d. & n.a. & n.a. & n.a. \\
\hline $\mathrm{FeO}$ & 21.8 & 21.2 & 20.5 & 21.1 & 21.7 \\
\hline $\mathrm{MnO}$ & 0.61 & 0.67 & 1.08 & 0.84 & 0.76 \\
\hline $\mathrm{MgO}$ & 8.28 & 8.35 & 8.75 & 8.67 & 8.74 \\
\hline $\mathrm{BaO}$ & n.d. & n.d. & 0.14 & 0.10 & 0.04 \\
\hline $\mathrm{CaO}$ & 12.0 & 11.3 & 12.1 & 11.6 & 11.7 \\
\hline $\mathrm{Na}_{2} \mathrm{O}$ & 1.41 & 1.16 & 1.48 & 1.42 & 1.47 \\
\hline $\mathrm{K}_{2} \mathrm{O}$ & 1.13 & 1.10 & 1.30 & 1.30 & 1.36 \\
\hline F & n.d. & n.d. & n.a. & n.a. & n.a. \\
\hline Total & 97.8 & 97.0 & 100.0 & 100.1 & 98.8 \\
\hline \multicolumn{6}{|c|}{ Stoichiometry based on 23 oxygens } \\
\hline $\mathrm{Si}$ & 6.57 & 6.70 & 6.52 & 6.56 & 6.46 \\
\hline $\mathrm{Ti}$ & 0.05 & 0.05 & 0.05 & 0.05 & 0.06 \\
\hline $\mathrm{Al}$ & 1.90 & 1.85 & 1.92 & 1.92 & 1.88 \\
\hline $\mathrm{Cr}$ & 0.00 & 0.00 & 0.00 & 0.00 & 0.00 \\
\hline $\mathrm{Fe}$ & 2.86 & 2.77 & 2.58 & 2.65 & 2.71 \\
\hline $\mathrm{Mn}$ & 0.08 & 0.09 & 0.14 & 0.11 & 0.10 \\
\hline $\mathrm{Mg}$ & 1.94 & 1.95 & 1.96 & 1.94 & 2.01 \\
\hline $\mathrm{Ba}$ & 0.00 & 0.00 & 0.01 & 0.01 & 0.00 \\
\hline $\mathrm{Ca}$ & 2.02 & 1.90 & 1.95 & 1.86 & 1.88 \\
\hline $\mathrm{Na}$ & 0.43 & 0.35 & 0.43 & 0.41 & 0.42 \\
\hline K & 0.23 & 0.22 & 0.25 & 0.25 & 0.26 \\
\hline $\mathrm{F}$ & 0.00 & 0.00 & 0.00 & 0.00 & 0.00 \\
\hline $\mathrm{Mg} /(\mathrm{Mg}+\mathrm{Fe}+\mathrm{Mn})$ & 0.40 & 0.41 & 0.42 & 0.41 & 0.42 \\
\hline
\end{tabular}




\begin{tabular}{|c|c|c|c|c|}
\hline \multicolumn{5}{|c|}{ EE-2 11100 clinopyroxene (amphibolite, junk basket) } \\
\hline & A-1 & A-2 & $\mathbf{A}-\mathbf{3}$ & A-4 \\
\hline \multicolumn{5}{|c|}{ Weight percent } \\
\hline $\mathrm{SiO}_{2}$ & 54.8 & 53.6 & 54.2 & 52.9 \\
\hline $\mathrm{TiO}_{2}$ & 0.04 & 0.03 & 0.00 & 0.13 \\
\hline $\mathrm{Al}_{2} \mathrm{O}_{3}$ & 0.20 & 0.72 & 0.44 & 1.02 \\
\hline $\mathrm{Cr}_{2} \mathrm{O}_{3}$ & n.d. & 0.06 & n.d. & n.d. \\
\hline $\mathrm{FeO}$ & 4.33 & 4.82 & 4.79 & 4.86 \\
\hline $\mathrm{MnO}$ & 0.37 & 0.31 & 0.29 & 0.25 \\
\hline $\mathrm{MgO}$ & 15.5 & 15.3 & 15.3 & 15.1 \\
\hline $\mathrm{CaO}$ & 24.9 & 25.1 & 25.0 & 24.7 \\
\hline $\mathrm{Na}_{2} \mathrm{O}$ & n.d. & 0.12 & 0.12 & 0.09 \\
\hline Total & 100.1 & 100.1 & 100.1 & 99.1 \\
\hline \multicolumn{5}{|c|}{ Stoichiometry based on 6 oxygens } \\
\hline $\mathrm{Si}$ & 2.01 & 1.98 & 2.00 & 1.97 \\
\hline $\mathrm{Ti}$ & 0.00 & 0.00 & 0.00 & 0.00 \\
\hline $\mathrm{Al}$ & 0.01 & 0.03 & 0.02 & 0.04 \\
\hline $\mathrm{Cr}$ & 0.00 & 0.00 & 0.00 & 0.00 \\
\hline $\mathrm{Fe}$ & 0.13 & 0.15 & 0.15 & 0.15 \\
\hline $\mathrm{Mn}$ & 0.01 & 0.01 & 0.01 & 0.01 \\
\hline $\mathrm{Mg}$ & 0.85 & 0.84 & 0.84 & 0.84 \\
\hline $\mathrm{Ca}$ & 0.98 & 0.99 & 0.98 & 0.98 \\
\hline $\mathrm{Na}$ & 0.00 & 0.01 & 0.01 & 0.01 \\
\hline
\end{tabular}




\begin{tabular}{|c|c|c|c|c|}
\hline \multicolumn{5}{|c|}{ Varietal minerals in leucogranites (bit cuttings) } \\
\hline & EE-3A 10010-15 & \multicolumn{3}{|c|}{ EE-2A 12025-30 tourmaline } \\
\hline & G-3 & A-1 & A-2 & A-3 \\
\hline \multicolumn{2}{|c|}{ Weight percent } & \multicolumn{3}{|c|}{ Weight percent (partial analyses) } \\
\hline $\mathrm{SiO}_{2}$ & 36.6 & 35.3 & 35.9 & 35.4 \\
\hline $\mathrm{TiO}_{2}$ & 0.32 & 0.37 & 0.19 & 0.38 \\
\hline $\mathrm{Al}_{2} \mathrm{O}_{3}$ & 20.7 & 29.0 & 29.4 & 28.6 \\
\hline $\mathrm{Cr}_{2} \mathrm{O}_{3}$ & n.d. & n.d. & n.d. & 0.00 \\
\hline $\mathrm{FeO}$ & 14.21 & 11.3 & 11.2 & 11.8 \\
\hline $\mathrm{MnO}$ & 26.84 & 0.06 & 0.14 & 0.10 \\
\hline $\mathrm{MgO}$ & 0.67 & 6.16 & 6.27 & 6.42 \\
\hline $\mathrm{CaO}$ & 0.62 & 0.57 & 0.57 & 0.62 \\
\hline $\mathrm{Na}_{2} \mathrm{O}$ & n.a. & 2.44 & 2.37 & 2.50 \\
\hline $\mathrm{K}_{2} \mathrm{O}$ & n.a. & 0.04 & n.d. & n.d. \\
\hline Total & 99.9 & 85.2 & 86.0 & 85.8 \\
\hline \multicolumn{2}{|c|}{ Stoichiometry based on 12 oxygens } & \multicolumn{3}{|c|}{ Stoichiometry based on 18 oxygens } \\
\hline $\mathrm{Si}$ & 2.99 & 4.41 & 4.43 & 4.41 \\
\hline $\mathrm{Ti}$ & 0.02 & 0.04 & 0.02 & 0.04 \\
\hline $\mathrm{Al}$ & 2.00 & 4.26 & 4.27 & 4.19 \\
\hline $\mathrm{Cr}$ & 0.00 & 0.00 & 0.00 & 0.00 \\
\hline $\mathrm{Fe}$ & 0.97 & 1.18 & 1.16 & 1.22 \\
\hline $\mathrm{Mn}$ & 1.86 & 0.01 & 0.02 & 0.01 \\
\hline $\mathrm{Mg}$ & 0.08 & 1.15 & 1.15 & 1.19 \\
\hline $\mathrm{Ca}$ & 0.05 & 0.08 & 0.08 & 0.08 \\
\hline $\mathrm{Na}$ & & 0.59 & 0.57 & 0.60 \\
\hline K & & 0.01 & 0.00 & 0.00 \\
\hline Pyrope & 2.7 & & & \\
\hline Almandine & 32.8 & & & \\
\hline Spessartine & 62.7 & & & \\
\hline Grossularite & 1.8 & & & \\
\hline
\end{tabular}




\begin{tabular}{|c|c|c|c|c|c|c|c|}
\hline \multicolumn{8}{|c|}{ EE-2 12849-3 sphene (biotite monzogranite, core 2) } \\
\hline & X-5 & X-7 & X-8 & X-9 & X-10 & $X-11$ & $X-12$ \\
\hline \multicolumn{8}{|c|}{ Weight percent } \\
\hline $\mathrm{SiO}_{2}$ & 29.3 & 30.3 & 29.3 & 30.2 & 30.5 & 29.1 & 30.0 \\
\hline $\mathrm{TiO}_{2}$ & 32.4 & 33.7 & 32.3 & 33.9 & 34.7 & 32.9 & 35.5 \\
\hline $\mathrm{Al}_{2} \mathrm{O}_{3}$ & 2.27 & 2.04 & 2.50 & 1.88 & 1.84 & 1.96 & 1.73 \\
\hline $\mathrm{Fe}_{2} \mathrm{O}_{3}$ & 2.31 & 2.44 & 2.89 & 2.13 & 2.23 & 2.47 & 1.36 \\
\hline $\mathrm{MnO}$ & 0.00 & 0.00 & 0.00 & 0.00 & 0.00 & n.d. & 0.00 \\
\hline $\mathrm{MgO}$ & n.d. & 0.00 & n.d. & 0.00 & 0.00 & 0.00 & 0.00 \\
\hline $\mathrm{CaO}$ & 24.6 & 27.3 & 25.3 & 26.4 & 27.1 & 24.3 & 27.0 \\
\hline $\mathrm{F}$ & 0.00 & n.d. & n.d. & n.d. & 0.00 & 0.00 & 0.00 \\
\hline $\mathrm{Ce}_{2} \mathrm{O}_{3}$ & 1.32 & 0.00 & 0.84 & 0.00 & 0.00 & 0.88 & 0.00 \\
\hline Total & 92.2 & 95.8 & 93.1 & 94.5 & 96.4 & 91.6 & 95.6 \\
\hline
\end{tabular}

\begin{tabular}{|c|c|c|c|c|c|c|c|}
\hline \multicolumn{8}{|c|}{ EE-2 12853-2 sphene (biotite monzogranite, core 2) } \\
\hline & $\mathrm{X}-2$ & $\mathbf{X - 3}$ & $\mathrm{X}-4$ & X-9 & $\mathrm{X}-10$ & $\mathrm{X}-11$ & $\mathrm{X}-12$ \\
\hline \multicolumn{8}{|c|}{ Weight percent } \\
\hline $\mathrm{SiO}_{2}$ & 30.3 & 29.2 & 29.9 & 30.2 & 30.0 & 29.8 & 29.9 \\
\hline $\mathrm{TiO}_{2}$ & 35.0 & 32.6 & 33.7 & 34.4 & 35.9 & 33.2 & 35.0 \\
\hline $\mathrm{Al}_{2} \mathrm{O}_{3}$ & 2.06 & 2.14 & 1.98 & 1.76 & 1.55 & 1.99 & 1.46 \\
\hline $\mathrm{Fe}_{2} \mathrm{O}_{3}$ & 2.06 & 2.78 & 2.23 & 2.07 & 1.80 & 1.82 & 1.47 \\
\hline $\mathrm{MnO}$ & n.d. & n.d. & n.d. & n.d. & n.d. & 0.16 & 0.13 \\
\hline $\mathrm{MgO}$ & n.d. & n.d. & 0.00 & 0.00 & n.d. & 0.00 & 0.00 \\
\hline $\mathrm{CaO}$ & 29.9 & 27.0 & 28.8 & 28.6 & 28.8 & 27.6 & 28.7 \\
\hline $\mathrm{F}$ & n.d. & n.d. & n.d. & n.d. & n.d. & n.d. & n.d. \\
\hline $\mathrm{Ce}_{2} \mathrm{O}_{3}$ & 0.00 & 0.50 & 0.00 & 0.00 & 0.00 & 0.48 & 0.00 \\
\hline Total & 99.3 & 94.2 & 96.6 & 97.0 & 98.1 & 95.1 & 96.7 \\
\hline
\end{tabular}




\begin{tabular}{|c|c|c|c|c|c|c|c|}
\hline \multicolumn{8}{|c|}{ EE-2 12853-2 sphene (biotite monzogranite, core 2 ) continued } \\
\hline & $\mathrm{X}-13$ & $X-14$ & $\mathrm{X}-15$ & $X-16$ & $\mathrm{X}-17$ & $\mathrm{X}-18$ & $\mathrm{X}-19$ \\
\hline \multicolumn{8}{|c|}{ Weight percent } \\
\hline $\mathrm{SiO}_{2}$ & 29.7 & 29.8 & 29.5 & 29.5 & 29.9 & 28.7 & 29.1 \\
\hline $\mathrm{TiO}_{2}$ & 33.9 & 34.0 & 32.5 & 32.7 & 34.5 & 34.6 & 33.0 \\
\hline $\mathrm{Al}_{2} \mathrm{O}_{3}$ & 2.03 & 1.92 & 2.00 & 2.11 & 1.65 & 1.84 & 2.04 \\
\hline $\mathrm{Fe}_{2} \mathrm{O}_{3}$ & 2.16 & 2.36 & 2.56 & 2.53 & 1.77 & 2.08 & 2.49 \\
\hline $\mathrm{MnO}$ & 0.14 & n.d. & n.d. & 0.10 & 0.10 & n.d. & 0.14 \\
\hline $\mathrm{MgO}$ & 0.00 & 0.00 & 0.00 & 0.00 & n.d. & n.d. & n.d. \\
\hline $\mathrm{CaO}$ & 27.0 & 28.0 & 27.4 & 27.8 & 28.0 & 26.6 & 26.5 \\
\hline $\mathrm{F}$ & n.d. & n.d. & n.d. & n.d. & n.d. & n.d. & n.d. \\
\hline $\mathrm{Ce}_{2} \mathrm{O}_{3}$ & 0.32 & 0.21 & n.d. & 0.26 & 0.00 & 0.55 & 0.54 \\
\hline Total & 95.3 & 96.3 & 94.0 & 95.0 & 95.9 & 94.4 & 93.8 \\
\hline
\end{tabular}

\begin{tabular}{|l|c|c|c|c|c|c|c|c|}
\hline \multicolumn{7}{|c|}{ EE-2 12853-2 sphene (biotite monzogranite, core 2) continued } \\
\hline & $\mathbf{X - 2 0}$ & $\mathbf{X - 2 1}$ & $\mathbf{X - 2 2}$ & $\mathbf{X - 2 3}$ & $\mathbf{X - 2 4}$ & $\mathbf{X - 2 5}$ & $\mathbf{X - 2 6}$ \\
\hline \multicolumn{7}{|c|}{ Weight percent } \\
\hline $\mathrm{SiO}_{2}$ & 29.7 & 29.2 & 29.8 & 29.5 & 28.8 & 29.8 & 29.4 \\
\hline $\mathrm{TiO}_{2}$ & 33.8 & 35.3 & 35.9 & 33.9 & 33.1 & 36.6 & 34.9 \\
\hline $\mathrm{Al}_{2} \mathrm{O}_{3}$ & 2.16 & 1.95 & 1.58 & 1.68 & 1.93 & 1.55 & 1.60 \\
\hline $\mathrm{Fe}_{2} \mathrm{O}_{3}$ & 2.46 & 1.66 & 1.59 & 2.10 & 2.80 & 1.64 & 1.81 \\
\hline $\mathrm{MnO}^{2}$ & n.d. & n.d. & n.d. & 0.12 & 0.20 & 0.10 & n.d. \\
\hline $\mathrm{MgO}^{2}$ & n.d. & n.d. & 0.00 & n.d. & n.d. & 0.00 & 0.00 \\
\hline $\mathrm{CaO}^{2}$ & 27.4 & 28.0 & 28.7 & 26.7 & 25.9 & 27.9 & 27.4 \\
\hline $\mathrm{F}$ & 3.0 & n.d. & n.d. & 0.00 & 0.00 & n.d. & 0.00 \\
\hline $\mathrm{Ce} \mathrm{O}_{3}$ & 0.30 & 0.00 & 0.00 & 0.23 & 0.38 & 0.00 & 0.00 \\
\hline $\mathrm{Total}$ & 98.8 & 96.1 & 97.6 & 94.2 & 93.1 & 97.6 & 95.1 \\
\hline
\end{tabular}




\begin{tabular}{|c|c|c|c|c|c|c|c|}
\hline \multicolumn{8}{|c|}{ EE-2 12853-2 sphene (biotite monzogranite, core 2) continued } \\
\hline & X-27 & X-28 & X-29 & X-30 & X-31 & X-32 & X-33 \\
\hline \multicolumn{8}{|c|}{ Weight percent } \\
\hline $\mathrm{SiO}_{2}$ & 29.0 & 30.3 & 29.7 & 30.1 & 28.6 & 29.5 & 29.2 \\
\hline $\mathrm{TiO}_{2}$ & 34.1 & 35.5 & 34.6 & 35.5 & 32.6 & 34.6 & 35.3 \\
\hline $\mathrm{Al}_{2} \mathrm{O}_{3}$ & 2.06 & 1.94 & 1.84 & 1.86 & 1.98 & 2.07 & 1.64 \\
\hline $\mathrm{Fe}_{2} \mathrm{O}_{3}$ & 2.67 & 1.95 & 2.08 & 1.82 & 2.53 & 2.30 & 1.68 \\
\hline $\mathrm{MnO}$ & 0.09 & 0.09 & 0.11 & 0.14 & n.d. & 0.15 & n.d. \\
\hline $\mathrm{MgO}$ & 0.00 & 0.00 & n.d. & 0.00 & 0.05 & n.d. & n.d. \\
\hline $\mathrm{CaO}$ & 26.7 & 28.2 & 26.8 & 27.7 & 24.7 & 27.3 & 26.4 \\
\hline $\mathrm{F}$ & n.d. & n.d. & 0.00 & n.d. & n.d. & n.d. & n.d. \\
\hline $\mathrm{Ce}_{2} \mathrm{O}_{3}$ & n.d. & 0.00 & 0.00 & 0.00 & 0.73 & 0.00 & 0.00 \\
\hline Total & 94.6 & 98.0 & 95.1 & 97.1 & 91.2 & 95.9 & 94.2 \\
\hline
\end{tabular}

\begin{tabular}{|c|c|c|c|c|c|}
\hline \multicolumn{6}{|c|}{ EE-2 12853-2 sphene (biotite monzogranite, core 2) continued } \\
\hline & \multicolumn{5}{|c|}{ biotite-plagioclase inclusions } \\
\hline & $\mathrm{X}-34$ & $\mathrm{X}-5$ & X-6 & $\mathrm{X}-7$ & $\mathbf{X - 8}$ \\
\hline \multicolumn{6}{|c|}{ Weight percent } \\
\hline $\mathrm{SiO}_{2}$ & 28.6 & 30.0 & 30.2 & 30.1 & 30.1 \\
\hline $\mathrm{TiO}_{2}$ & 32.5 & 34.7 & 35.9 & 35.1 & 35.9 \\
\hline $\mathrm{Al}_{2} \mathrm{O}_{3}$ & 2.20 & 1.69 & 1.87 & 1.77 & 1.70 \\
\hline $\mathrm{Fe}_{2} \mathrm{O}_{3}$ & 2.70 & 1.78 & 1.88 & 1.71 & 1.68 \\
\hline $\mathrm{MnO}$ & 0.13 & n.d. & n.d. & n.d. & 0.00 \\
\hline $\mathrm{MgO}$ & 0.09 & 0.00 & 0.00 & 0.00 & 0.00 \\
\hline $\mathrm{CaO}$ & 25.1 & 28.3 & 29.0 & 28.9 & 29.3 \\
\hline $\mathrm{F}$ & n.d. & n.d. & n.d. & n.d. & n.d. \\
\hline $\mathrm{Ce}_{2} \mathrm{O}_{3}$ & 0.71 & 0.00 & 0.00 & 0.00 & 0.00 \\
\hline Total & 92.0 & 96.5 & 98.9 & 97.6 & 98.7 \\
\hline
\end{tabular}




\begin{tabular}{|c|c|c|c|c|c|c|c|}
\hline \multicolumn{8}{|c|}{ EE-3A 11615-8A sphene (biotite monzogranite, core 3) } \\
\hline & X-1 & $X-2$ & $X-3$ & $X-4$ & $X-5$ & X-8 & X-10 \\
\hline \multicolumn{8}{|c|}{ Weight percent } \\
\hline $\mathrm{SiO}_{2}$ & 29.8 & 29.9 & 29.7 & 29.7 & 29.6 & 29.8 & 29.2 \\
\hline $\mathrm{TiO}_{2}$ & 35.3 & 34.0 & 33.6 & 34.2 & 33.9 & 34.1 & 34.2 \\
\hline $\mathrm{Al}_{2} \mathrm{O}_{3}$ & 1.67 & 1.99 & 2.01 & 1.95 & 2.25 & 1.90 & 1.68 \\
\hline $\mathrm{Fe}_{2} \mathrm{O}_{3}$ & 1.51 & 2.27 & 2.24 & 2.48 & 2.13 & 2.03 & 2.18 \\
\hline $\mathrm{MnO}$ & n.d. & n.d. & n.d. & 0.10 & 0.40 & n.d. & 0.00 \\
\hline $\mathrm{MgO}$ & 0.00 & 0.00 & 0.00 & 0.00 & 0.00 & 0.00 & n.d. \\
\hline $\mathrm{CaO}$ & 28.0 & 28.6 & 27.3 & 28.6 & 26.7 & 28.5 & 27.5 \\
\hline $\mathrm{F}$ & 0.00 & n.d. & n.d. & n.d. & n.d. & n.d. & 0.00 \\
\hline $\mathrm{Ce}_{2} \mathrm{O}_{3}$ & n.d. & 0.00 & 0.00 & 0.00 & 0.32 & 0.00 & n.d. \\
\hline Total & 96.3 & 96.8 & 94.9 & 97.0 & 95.3 & 96.3 & 94.8 \\
\hline
\end{tabular}

\begin{tabular}{|c|c|c|c|c|c|c|c|}
\hline \multicolumn{8}{|c|}{ EE-3A 11615-8A sphene (biotite monzogranite. core 3), continued } \\
\hline & X-11 & X-12 & X-14 & X-15 & X-16 & F-1 & F-2 \\
\hline \multicolumn{8}{|c|}{ Weight percent } \\
\hline $\mathrm{SiO}_{2}$ & 29.4 & 29.7 & 29.7 & 29.3 & 29.2 & 30.6 & 30.2 \\
\hline $\mathrm{TiO}_{2}$ & 34.8 & 33.4 & 33.8 & 33.3 & 34.4 & 34.3 & 33.5 \\
\hline $\mathrm{Al}_{2} \mathrm{O}_{3}$ & 1.76 & 1.82 & 1.90 & 2.04 & 1.95 & 2.98 & 2.92 \\
\hline $\mathrm{Fe}_{2} \mathrm{O}_{3}$ & 1.83 & 2.32 & 1.90 & 2.54 & 2.40 & 1.39 & 1.44 \\
\hline $\mathrm{MnO}$ & n.d. & n.d. & n.d. & n.d. & n.d. & n.d. & n.d. \\
\hline $\mathrm{MgO}$ & 0.00 & 0.00 & 0.00 & n.d. & 0.00 & 0.00 & 0.00 \\
\hline $\mathrm{CaO}$ & 27.4 & 27.1 & 28.4 & 27.4 & 28.0 & 30.5 & 29.1 \\
\hline $\mathrm{F}$ & n.d. & 0.00 & 0.00 & n.d. & 0.00 & n.d. & n.d. \\
\hline $\mathrm{Ce}_{2} \mathrm{O}_{3}$ & 0.00 & 0.21 & 0.00 & n.d. & 0.00 & 0.00 & 0.00 \\
\hline Total & 95.2 & 94.6 & 95.7 & 94.6 & 96.0 & 99.8 & 97.2 \\
\hline
\end{tabular}




\begin{tabular}{|c|c|c|c|c|c|}
\hline \multicolumn{6}{|c|}{ EE-3A 9450-5C-8 sphene (partly recrystallized amphibolite in leucogranite dike, core 1) } \\
\hline & $\mathrm{X}-5$ & X-6 & $\mathbf{X}-7$ & A-15 & A-16 \\
\hline \multicolumn{6}{|c|}{ Weight percent } \\
\hline $\mathrm{SiO}_{2}$ & 29.1 & 29.8 & 29.9 & 29.7 & 30.0 \\
\hline $\mathrm{TiO}_{2}$ & 34.8 & 35.0 & 34.6 & 33.9 & 34.7 \\
\hline $\mathrm{Al}_{2} \mathrm{O}_{3}$ & 1.49 & 1.62 & 1.50 & 1.75 & 1.56 \\
\hline $\mathrm{Fe}_{2} \mathrm{O}_{3}$ & 1.75 & 1.92 & 1.77 & 1.80 & 1.72 \\
\hline $\mathrm{MnO}$ & n.d. & 0.27 & n.d. & n.d. & 0.10 \\
\hline $\mathrm{MgO}$ & 0.00 & 0.00 & 0.00 & 0.00 & 0.00 \\
\hline $\mathrm{CaO}$ & 27.9 & 28.8 & 27.4 & 28.4 & 28.5 \\
\hline $\mathrm{F}$ & n.d. & n.d. & n.d. & n.d. & n.d. \\
\hline $\mathrm{Ce}_{2} \mathrm{O}_{3}$ & 0.00 & 0.00 & 0.00 & 0.00 & 0.00 \\
\hline Total & 95.0 & 97.4 & 95.2 & 95.6 & 96.6 \\
\hline
\end{tabular}

\begin{tabular}{|c|c|c|c|c|c|c|c|}
\hline \multicolumn{8}{|c|}{ EE-3A 12438-51C sphene (amphibolite, core 4) } \\
\hline & $\mathrm{X}-1$ & $\mathrm{X}-2$ & $\mathrm{X}-3$ & $X-4$ & $\mathrm{X}-5$ & X-6 & $\mathrm{X}-7$ \\
\hline \multicolumn{8}{|c|}{ Weight percent } \\
\hline $\mathrm{SiO}_{2}$ & 30.4 & 30.0 & 30.6 & 29.8 & 30.1 & 30.1 & 30.3 \\
\hline $\mathrm{TiO}_{2}$ & 34.9 & 36.5 & 36.6 & 36.2 & 36.2 & 37.0 & 37.6 \\
\hline $\mathrm{Al}_{2} \mathrm{O}_{3}$ & 1.31 & 1.20 & 1.22 & 1.17 & 1.37 & 1.29 & 1.00 \\
\hline $\mathrm{Fe}_{2} \mathrm{O}_{3}$ & 1.27 & 1.09 & 1.34 & 1.24 & 1.40 & 1.20 & 0.82 \\
\hline $\mathrm{MnO}$ & n.d. & n.d. & 0.09 & 0.14 & n.d. & 0.11 & 0.08 \\
\hline $\mathrm{MgO}$ & 0.00 & 0.00 & 0.00 & 0.00 & 0.00 & 0.00 & 0.00 \\
\hline $\mathrm{CaO}$ & 29.9 & 28.8 & 30.0 & 28.7 & 29.5 & 29.1 & 29.6 \\
\hline $\mathrm{F}$ & 0.00 & 0.00 & 0.00 & 0.00 & 0.00 & 0.00 & 0.00 \\
\hline $\mathrm{Ce}_{2} \mathrm{O}_{3}$ & 0.00 & 0.00 & 0.00 & 0.00 & 0.00 & 0.00 & 0.00 \\
\hline Total & 97.8 & 97.6 & 99.9 & 97.3 & 98.6 & 98.8 & 99.4 \\
\hline
\end{tabular}




\begin{tabular}{|c|c|c|c|c|}
\hline \multicolumn{5}{|c|}{ EE-2 12849-3 sphene (biotite-plagioclase rock, core 2) } \\
\hline & $\mathrm{X}-16$ & $\mathrm{X}-17$ & $X-18$ & X-19 \\
\hline \multicolumn{5}{|c|}{ Weight percent } \\
\hline $\mathrm{SiO}_{2}$ & 30.2 & 30.3 & 29.9 & 30.4 \\
\hline $\mathrm{TiO}_{2}$ & 33.8 & 33.4 & 33.6 & 34.2 \\
\hline $\mathrm{Al}_{2} \mathrm{O}_{3}$ & 1.90 & 2.05 & 1.85 & 1.81 \\
\hline $\mathrm{Fe}_{2} \mathrm{O}_{3}$ & 2.06 & 2.19 & 1.89 & 1.84 \\
\hline $\mathrm{MnO}$ & 0.15 & 0.09 & 0.13 & 0.09 \\
\hline $\mathrm{MgO}$ & 0.00 & 0.00 & 0.00 & 0.00 \\
\hline $\mathrm{CaO}$ & 27.9 & 28.6 & 27.2 & 27.9 \\
\hline $\mathrm{F}$ & n.d. & 0.00 & 0.00 & 0.00 \\
\hline $\mathrm{Ce}_{2} \mathrm{O}_{3}$ & 0.00 & 0.00 & n.d. & 0.00 \\
\hline Total & 96.0 & 96.6 & 94.6 & 96.2 \\
\hline
\end{tabular}

\begin{tabular}{|c|c|c|c|c|c|c|c|}
\hline \multicolumn{8}{|c|}{ EE-2 12851-4A sphene (biotite-plagioclase rock, core 2) } \\
\hline & \multicolumn{4}{|c|}{ 0.6-mm subhedral crystal } & \multicolumn{3}{|c|}{ groundmass crystals } \\
\hline & A-1 & A-3 & A-4 & A-5 & A-6 & A-7 & $\mathrm{X}-1$ \\
\hline \multicolumn{8}{|c|}{ Weight percent } \\
\hline $\mathrm{SiO}_{2}$ & 30.0 & 29.9 & 29.3 & 30.5 & 30.4 & 30.7 & 30.4 \\
\hline $\mathrm{TiO}_{2}$ & 33.8 & 34.4 & 34.1 & 35.6 & 35.5 & 34.4 & 35.4 \\
\hline $\mathrm{Al}_{2} \mathrm{O}_{3}$ & 1.46 & 1.33 & 1.43 & 1.24 & 1.35 & 1.56 & 1.28 \\
\hline $\mathrm{Fe}_{2} \mathrm{O}_{3}$ & 1.83 & 1.18 & 1.78 & 1.07 & 1.48 & 1.50 & 1.17 \\
\hline $\mathrm{MnO}$ & 0.00 & n.d. & n.d. & n.d. & n.d. & 0.00 & n.d. \\
\hline $\mathrm{MgO}$ & 0.00 & 0.00 & 0.00 & 0.00 & 0.00 & 0.00 & 0.00 \\
\hline $\mathrm{CaO}$ & 27.2 & 28.6 & 27.9 & 28.5 & 28.7 & 28.6 & 29.3 \\
\hline $\mathrm{F}$ & n.d. & 0.00 & 0.00 & 0.00 & 0.00 & 0.00 & 0.00 \\
\hline $\mathrm{Ce}_{2} \mathrm{O}_{3}$ & n.d. & 0.00 & 0.17 & 0.00 & 0.00 & 0.00 & 0.00 \\
\hline Total & 94.3 & 95.4 & 94.7 & 96.9 & 97.4 & 96.8 & 97.6 \\
\hline
\end{tabular}




\begin{tabular}{|c|c|c|c|c|c|c|c|}
\hline \multicolumn{8}{|c|}{ EE-2 12852-1C sphene (biotite-plagioclase rock, core 2) } \\
\hline & \multicolumn{7}{|c|}{ pale brown, irregular groundmass crystals $<0.25 \mathrm{~mm}$} \\
\hline & B-6 & C-6 & D-8 & E-4 & E-6 & E-7 & E-8 \\
\hline \multicolumn{8}{|c|}{ Weight percent } \\
\hline $\mathrm{SiO}_{2}$ & 30.0 & 30.4 & 30.1 & 30.0 & 29.5 & 30.4 & 30.4 \\
\hline $\mathrm{TiO}_{2}$ & 35.7 & 36.0 & 37.0 & 34.7 & 33.3 & 34.8 & 34.6 \\
\hline $\mathrm{Al}_{2} \mathrm{O}_{3}$ & 1.89 & 1.85 & 1.72 & 2.04 & 1.66 & 1.93 & 2.52 \\
\hline $\mathrm{Fe}_{2} \mathrm{O}_{3}$ & 2.31 & 2.03 & 1.73 & 2.39 & 1.77 & 2.09 & 1.47 \\
\hline $\mathrm{MnO}$ & 0.04 & 0.12 & 0.06 & 0.17 & 0.00 & 0.00 & 0.00 \\
\hline $\mathrm{MgO}$ & n.d. & n.d. & n.d. & n.d. & 0.00 & 0.00 & 0.00 \\
\hline $\mathrm{CaO}$ & 27.8 & 28.3 & 27.4 & 27.3 & 29.2 & 27.4 & 28.4 \\
\hline $\mathrm{F}$ & n.d. & n.d. & n.d. & n.d. & 0.00 & 0.00 & 0.00 \\
\hline $\mathrm{Ce}_{2} \mathrm{O}_{3}$ & n.d. & n.d. & n.d. & n.d. & 0.00 & 0.00 & 0.00 \\
\hline $\mathrm{La}_{2} \mathrm{O}_{3}$ & n.a. & n.a. & n.a. & n.a. & 0.24 & 0.17 & 0.11 \\
\hline $\mathrm{Y}_{2} \mathrm{O}_{3}$ & n.a. & n.a. & n.a. & n.a. & 0.06 & 0.06 & n.d. \\
\hline $\mathrm{ZrO}_{2}$ & n.a. & n.a. & n.a. & n.a. & 0.00 & 0.00 & 0.00 \\
\hline Total & 97.7 & 98.7 & 98.0 & 96.6 & 95.7 & 96.9 & 97.5 \\
\hline
\end{tabular}




\begin{tabular}{|c|c|c|c|c|c|}
\hline \multicolumn{6}{|c|}{ EE-2 12852-1C sphene (biotite-plagioclase rock, core 2) continued } \\
\hline & groundmass & $\begin{array}{c}\text { rim on euhedral } \\
\text { crystal }\end{array}$ & \multicolumn{3}{|c|}{ 0.4-mm euhedral crystal } \\
\hline & E-9 & E-2 & E-1 & E-3 & E-5 \\
\hline \multicolumn{6}{|c|}{ Weight percent } \\
\hline $\mathrm{SiO}_{2}$ & 28.8 & 30.2 & 28.8 & 28.9 & 28.9 \\
\hline $\mathrm{TiO}_{2}$ & 34.7 & 36.4 & 33.0 & 31.9 & 32.7 \\
\hline $\mathrm{Al}_{2} \mathrm{O}_{3}$ & 1.68 & 1.48 & 2.27 & 2.29 & 2.20 \\
\hline $\mathrm{Fe}_{2} \mathrm{O}_{3}$ & 1.88 & 1.54 & 3.02 & 2.99 & 2.90 \\
\hline $\mathrm{MnO}$ & 0.00 & 0.00 & n.d. & n.d. & n.d. \\
\hline $\mathrm{MgO}$ & 0.00 & 0.00 & n.d. & n.d. & 0.00 \\
\hline $\mathrm{CaO}$ & 28.4 & 26.7 & 24.9 & 24.9 & 25.2 \\
\hline $\mathrm{F}$ & 0.00 & 0.00 & n.d. & 0.00 & 0.00 \\
\hline $\mathrm{Ce}_{2} \mathrm{O}_{3}$ & 0.00 & 0.00 & 0.78 & 0.91 & 0.95 \\
\hline $\mathrm{La}_{2} \mathrm{O}_{3}$ & 0.1 & 0.25 & 0.53 & 0.56 & 0.67 \\
\hline $\mathrm{Y}_{2} \mathrm{O}_{3}$ & n.d. & 0.14 & 1.45 & 1.34 & 0.89 \\
\hline $\mathrm{ZrO}_{2}$ & 0.00 & 0.00 & 0.00 & 0.00 & 0.00 \\
\hline Total & 95.6 & 96.7 & 94.8 & 93.8 & 94.4 \\
\hline
\end{tabular}




\section{APPENDIX B \\ LEUCOGRANITE DISTRIBUTION AT FENTON HILL}

The values reported here are in volume percent of cutting samples from the indicated drilling depth intervals (in feet), based on visual estimates. For samples with low leucogranite contents, accuracy of estimate varies with factors that make it more or less difficult to identify the leucogranite. In many cases, leucogranite contents of about $3 \%$ or less may be lag materials unrelated to the nominal sample depth. Fine-grained or contaminated cuttings, cuttings of highly altered rock, and cuttings with main rock types similar to leucogranite all hinder the estimation of leucogranite content. A "--" in the percent column indicates samples that are too fine, contaminated, missing, or not examined.

\section{EE-2A}

9,742-50: 0

9,750-60: 0

9,760-70: 0

9,770-80: 10

9,780-90: 5

9,790-800: 1

9,800-10: 0

9,810-20: >0

9,820-30: 0

9,830-40: 0

9,840-50: 10

9,850-60: 0

9,860-70: 5

9,870-80: 5

9,880-90: 5

9,890-900: 2

9,900-10: 2

9,910-20: 1

9,920-30: 10

9,930-40: 10

9,940-50: 5

9,950-60: 0
9,960-70: 90

9,970-80: 60

9,980-90: 20

9,990-10,000: 20

10,000-10: 10

10,010-20: 5

10,020-30: 20

10,030-40: 20

10,040-50: --

10,050-60: 0

10,060-70: 5

10,070-80: 20

10,080-90: 0

10,090-10,100: 10

10,100-10: 40

10,110-20: 30

10,120-30: 20

10,130-40: 5

10,140-50: 3

10,150-60: 3

10,160-70: 0

10,170-80: 2
10,180-90: 0

10,190-200: 2

10,200-10: 5

10,210-20: 5

10,220-30: 5

10,230-40: 5

10,240-50: 3

10,250-60: 15

10,260-70: 10

10,270-80: 5

10,280-90: 0

10,290-300: 10

10,300-10: 0

10,310-20: 0

10,320-30: 0

10,330-40: 0

10,340-50: 0

10,350-60: 0

10,360-70: 0

10,370-80: 0

10,380-90: 0

10,390-400: 0 
10,400-10: 0

10,410-20: 10

10,420-30: --

10,430-40: 0

10,440-50: 0

10,450-60: 2

10,460-70: 1

10,470-80: 10

10,480-90: 3

10,490-500: 5

10,500-10: 10

10,510-20: 10

10,520-30: 10

10,530-40: 10

10,540-50: 60

10,550-60: 5

10,560-70: 20

10,570-80: 15

10,580-90: 20

10,590-600: 30

10,600-10: 20

10,610-20: 40

10,620-30: 50

10,630-40: 10

10,640-45: 10

10,650-60: --

10,660-70: --

10,670-80:--

10,680-85: 0

10,690-95: 0

10,700-05: 0

10,710-15: 0

10,720-30: --

10,730-40:--

10,740-50: --

10,750-55: 10
10,760-65: --

10,770-75: --

10,780-85: --

10,790-95: --

10,800-05: 0

10,810-15: --

10,820-25: --

10,825-30: 2

10,830-35: 2

10,840-45: --

10,845-50: 0

10,850-55: 0

10,860-70: --

10,870-80: --

10,880-90: --

10,890-900: --

10,900-10: 0

10,910-20: --

10,920-30: 0

10,930-40: 5

10,940-50: --

10,950-60: --

10,960-70: 0

10,970-80: --

10,980-90: --

10,990-11,000: 50

11,000-10: 50

11,010-20: --

11,020-30: --

11,030-40: 5

11,040-50: --

11,050-60: 10

11,065-70: 50

11,070-80: --

11,080-90: --
11,095-100: 0

11,100-05: 10

11,105-10: 10

11,110-15: 10

11,120-25: 25

11,125-30: >0

11,130-40: 0

11,140-45: 20

11,145-50: 20

11,150-60: --

11,165-70: 5

11,170-75: 5

11,180-90: --

11,190-200: --

11,200-10: >0

11,210-20: --

11,220-30:--

11,230-40: 0

11,240-50: 5

11,250-60: 98

11,260-70: --

11,270-80:--

11,280-90: --

11,290-300 :--

11,300-10: 98

11,310-20: --

11,320-30: 70

11,330-40: 40

11,340-50: --

11,350-60: 3

11,360-70: --

11,370-80:--

11,380-90: --

11,390-400: --

11,400-10: 4

11,410-20: <1 
11,420-30: 0

11,430-40: 0

11,440-50: 0

11,450-60: <1

11,460-70: 2

11,470-80: 0

11,480-90: 0

11,490-500: 10

11,500-10: 0

11,510-20: 1

11,520-30: 5

11,530-40: 0

11,540-50: <1

11,550-60: 3

11,560-70: 0

11,570-80: <1

11,580-90: 5

11,590-600:0

11,600-10: 0

$11,610-20:<1$

11,620-30: 5

11,630-35: 1

11,635-40: 5

$11,640-45:<1$

11,650-55: 0

11,655-60: 0

11,660-65: 0

11,670-75: 0

11,680-90: <1

11,690-95:<1

11,695-700: 0

11,700-05: 3

11,710-15: 5

11,720-25: 15

11,725-30: 10
11,730-35: 1

11,740-45: 2

11,750-55: 1

11,760-65: 1

11,770-75: 1

11,780-85: 10

11,790-95: 95

11,795-800: 15

11,800-05: 5

11,810-15: 10

11,820-25: 0

11,830-35: 10

11,840-45: 10

11,845-50: 5

11,850-55: 2

11,860-65: 5

11,870-80: --

11,880-85: 1

11,890-95: 3

11,900-05: 0

11,910-15: 0

11,920-25: 0

11,930-35: 0

11,935-40: 0

11,940-45: 10

11,945-50: 30

11,950-55: 5

11,960-65: 0

11,970-75: 5

11,980-85: 5

11,990-95: 1

12,000-05: 10

12,010-15: 0

12,015-20: 1

12,020-25: 2

12,025-30: 5
12,035-40: 20

12,040-45: 20

12,045-50: 20

12,050-55: 20

12,055-60: 0

12,060-70: 0

12,070-80: 2

12,080-90: 0

12,090-100:5

12,100-10: 3

12,110-20: 1

12,120-30: --

12,130-40: 50

12,140-50: 5

12,150-60: 15

12,160-70: 5

12,170-80: 0

12,180-90: 0

12,190-200: 0

12,200-10: 2

12,210-20: 0

12,220-30: 0

12,230-40: 25

12,240-50: 10

12,250-60: 3

12,260-70: 90

12,270-80: 0

12,280-90: 0

12,290-300: 3

12,300-10: 0

12,310-20: 2

12,320-30: 20

12,330-40: 0

12,340-50: --

12,350: 2 


\section{EE-3A}

\begin{tabular}{|c|c|c|}
\hline $9,595-600: 5$ & $9,940-45: 90$ & 10,290-300: 2 \\
\hline $9,600-05: 5$ & $9,950-55: 90$ & 10,300-10: 2 \\
\hline $9,610-15: 5$ & $9,960-65: 20$ & 10,310-20: 2 \\
\hline $9,620-25:>0$ & $9,970-75: 5$ & 10,320-30: 2 \\
\hline 9,630-35: 60 & $9,980-85: 5$ & 10,330-40: 10 \\
\hline $9,640-45: 90$ & $9,990-95: 5$ & $10,340-50: 3$ \\
\hline $9,650-55: 70$ & 10,000-05: 20 & $10,350-60: 3$ \\
\hline $9,660-65: 25$ & 10,010-15: 20 & $10,360-70: 5$ \\
\hline $9,670-75: 20$ & $10,020-25: 20$ & 10,370-80: 5 \\
\hline $9,680-85: 20$ & $10,030-35: 20$ & 10,380-90: 5 \\
\hline $9,690-95: 3$ & 10,040-45: 10 & 10,390-400: 5 \\
\hline 9,700-05: 40 & $10,050-55: 5$ & $10,400-10: 5$ \\
\hline $9,710-15: 3$ & $10,060-65: 5$ & 10,410-20: 5 \\
\hline $9,720-25: 3$ & $10,070-75: 5$ & $10,420-30: 5$ \\
\hline $9,730-35: 5$ & $10,080-85: 2$ & $10,430-40: 5$ \\
\hline 9,740-45: 90 & $10,090-95: 2$ & 10,440-50: 10 \\
\hline $9,750-55: 50$ & $10,100-05: 5$ & 10,450-60: >0 highly altered \\
\hline $9,760-65: 15$ & $10,110-15: 5$ & 10,460-70: >0 highly altered \\
\hline $9,770-75: 5$ & $10,120-25: 5$ & 10,470-80: >0 highly altered \\
\hline $9,780-85: 5$ & $10,130-40: 5$ & 10,480-90: >0 highly altered \\
\hline $9,790-95: 5$ & 10,140-50: 10 & 10,490-500: $>0$ highly altered \\
\hline 9,800-05: 30 & 10,150-60: 15 & 10,500-10: >0 highly altered \\
\hline 9,810-15: 80 & 10,160-70: 10 & 10,510-20: >0 highly altered \\
\hline $9,820-25: 80$ & 10,170-80: 5 & 10,520-30: >0 highly altered \\
\hline 9,830-35: 95 & 10,180-90: 5 & 10,530-40: >0 highly altered \\
\hline 9,840-45: 95 & 10,190-200: 2 & $10,540-50: 2$ \\
\hline 9,850-55: 99 & 10,200-10: -- & $10,550-60: 5$ \\
\hline 9,860-65: 99 & 10,210-20: -- & $10,560-70: 5$ \\
\hline 9,870-75: 95 & 10,220-30: -- & \\
\hline 9,880-85: 10 & $10,230-40: 5$ & \\
\hline 9,890-95: 85 & 10,240-50: 2 & \\
\hline 9,900-05: 98 & 10,250-60: -- & \\
\hline 9,910-15: 98 & 10,260-70: -- & \\
\hline $9,920-25: 50$ & 10,270-80: 5 & \\
\hline 9,930-35: 20 & 10,280-90: 2 & \\
\hline
\end{tabular}




\begin{tabular}{|c|c|c|}
\hline 10,570-80: -- & 10,930-40: 10 & 11,280-90: 10 \\
\hline 10,580-90: -- & 10,940-50: $>0$ & 11,290-300: 5 \\
\hline 10,590-600: -- & 10,950-60: >0 & 11,300-10: 5 \\
\hline 10,600-10: 20 & 10,960-70: $>0$ & 11,310-20: \\
\hline 10,610-20: 20 & 10,970-80: >0 & 11,320-30: \\
\hline 10,620-30: 20 & 10,980-90: >0 & 11,330-40: \\
\hline 10,630-40: 20 & 10,990-11,000: 0 & 11,340-50: 3 \\
\hline 10,640-50: 20 & 11,350-60: 2 & 11,360-70: 2 \\
\hline 10,650-60: 20 & 11,000-10: 0 & 11,370-80: 20 \\
\hline 10,660-70: 25 & 11,010-20: $>0$ & 11,380-90: 20 \\
\hline 10,670-80: -- & 11,020-30: $>0$ & 11,390-11,400: 20 \\
\hline 10,680-90: -- & 11,030-40: $>0$ & 11,400-10: 10 \\
\hline 10,690-700: -- & 11,040-50: >0 & 11,410-20: 50 \\
\hline 10,700-10: 0 & 11,050-60: >0 & 11,420-30: 20 \\
\hline 10,710-20: $>0$ & 11,060-70: $>0$ & 11,430-40: 20 \\
\hline 10,720-30: $>0$ & 11,070-80: 25 & 11,440-50: 20 \\
\hline $10,730-40:>0$ & 11,080-90: 10 & 11,450-60: 10 \\
\hline 10,740-50: $>0$ & 11,090-100: 50 & 11,460-70: 0 \\
\hline 10,750-60: $>0$ & 11,100-10: 50 & 11,470-80: 1 \\
\hline $10,760-70: 5$ & 11,110-20: 50 & 11,480-90: 10 \\
\hline 10,770-80: 5 & 11,120-30: 30 & 11,490-500: 5 \\
\hline $10,780-90: 5$ & 11,130-40: 30 & $11,500-10: 5$ \\
\hline 10,790-800: 5 & 11,140-50: 30 & 11,510-20: 5 \\
\hline 10,800-10: 30 & 11,150-60: 20 & 11,520-30: 5 \\
\hline 10,810-20: -- & 11,160-70: 20 & 11,530-40: 5 \\
\hline 10,820-30: 1 & 11,170-80: 20 & 11,540-50: 5 \\
\hline 10,830-40: 0 & 11,180-90: 20 & 11,550-60: 5 \\
\hline 10,840-50: $>0$ & 11,190-200: 20 & 11,560-70: 10 \\
\hline 10,850-60: $>0$ & 11,200-10: 20 & 11,570-80: 30 \\
\hline 10,860-70: 10 & 11,210-20: 20 & 11,580-90: 50 \\
\hline 10,870-80: >30 & 11,220-30: 10 & 11,590-600: 50 \\
\hline 10,880-90: 95 & 11,230-40: 10 & 11,600-10: 100 \\
\hline 10,890-900: 95 & 11,240-50: 10 & 11,610-20: 70 \\
\hline 10,900-10: 0 & 11,250-60: 10 & 11,620-30: -- \\
\hline 10,910-20: 0 & 11,260-70: 10 & \\
\hline 10,920-30: 10 & 11,270-80: 10 & \\
\hline
\end{tabular}




$\begin{array}{lll}11,630-40:-- & 11,990-12,000: 1 & 12,340-50: 5 \\ 11,640-50:-- & 12,000-10: 2 & 12,350-60: 5 \\ 11,650-60: 3 & 12,010-20: 1 & 12,360-70: 20 \\ 11,660-70: 5 & 12,020-30: 0 & 12,370-80: 70 \\ 11,670-80: 10 & 12,030-40: 1 & 12,380-90: 40 \\ 11,680-90:-- & 12,040-50: 1 & 12,390-400: 60 \\ 11,690-700: 10 & 12,050-60: 60 & 12,400-10: 40 \\ 11,700-10: 5 & 12,060-70: 1 & 12,410-20: 15 \\ 11,710-20: 5 & 12,070-80: 5 & 12,420-30: 10 \\ 11,720-30: 5 & 12,080-90: 1 & 12,430-40:-- \\ 11,730-40: 15 & 12,090-100: 2 & 12,440-50:-- \\ 11,740-50: 2 & 12,100-10: 10 & 12,450-60:>0 \\ 11,750-60: 5 & 12,110-20: 5 & 12,460-70:>0 \\ 11,760-70: 5 & 12,120-30: 35 & 12,470-80:>0 \\ 11,770-80: 2 & 12,130-40: 60 & 12,480-90:>0 \\ 11,780-90: 2 & 12,140-50: 10 & 12,490-500:>0 \\ 11,790-800: 10 & 12,150-60: 10 & 12,500-10:-- \\ 11,800-10: 0 & 12,160-70: 30 & 12,510-20:>0 \\ 11,810-20: 0 & 12,170-80: 0 & 12,520-30:>0 \\ 11,820-30: 5 & 12,180-90:>0 & 12,530-40:>0 \\ 11,830-40: 2 & 12,190-200: 0 & 12,540-50:>0 \\ 11,840-50: 2 & 12,200-10:-- & 12,550-60:>0 \\ 11,850-60: 5 & 12,210-20: 5 & 12,560-70:>0 \\ 11,860-70: 5 & 12,220-30: 5 & 12,570-80:>0 \\ 11,870-80: 5 & 12,230-40: 40 & 12,580-90:>0 \\ 11,880-90: 10 & 12,240-50: 60 & 12,590-600: 5 \\ 11,890-900: 10 & 12,250-60: 50 & 12,600-10: 98 \\ 11,900-10: 3 & 12,260-70: 5 & 12,610-20: 98 \\ 11,910-20: 20 & 12,270-80: 20 & 12,620-30: 50 \\ 11,920-30: 2 & 12,280-90: 20 & 12,630-40: 5 \\ 11,930-40: 2 & 12,290-300: 10 & 12,640-50: 5 \\ 11,940-50: 1 & 12,300-10: 10 & 12,650-60: 5 \\ 11,950-60:-- & 12,660-70: 2 \\ 11,960-70: 2 & 12,310-20: 10 & 12,670-80: 50 \\ 11,970-80: 2 & 12,320-30:>0 & 12,680-90: 50 \\ 11,980-90: 1 & 12,330-40:>0 & 12,690-700:>0 \\ & & \end{array}$




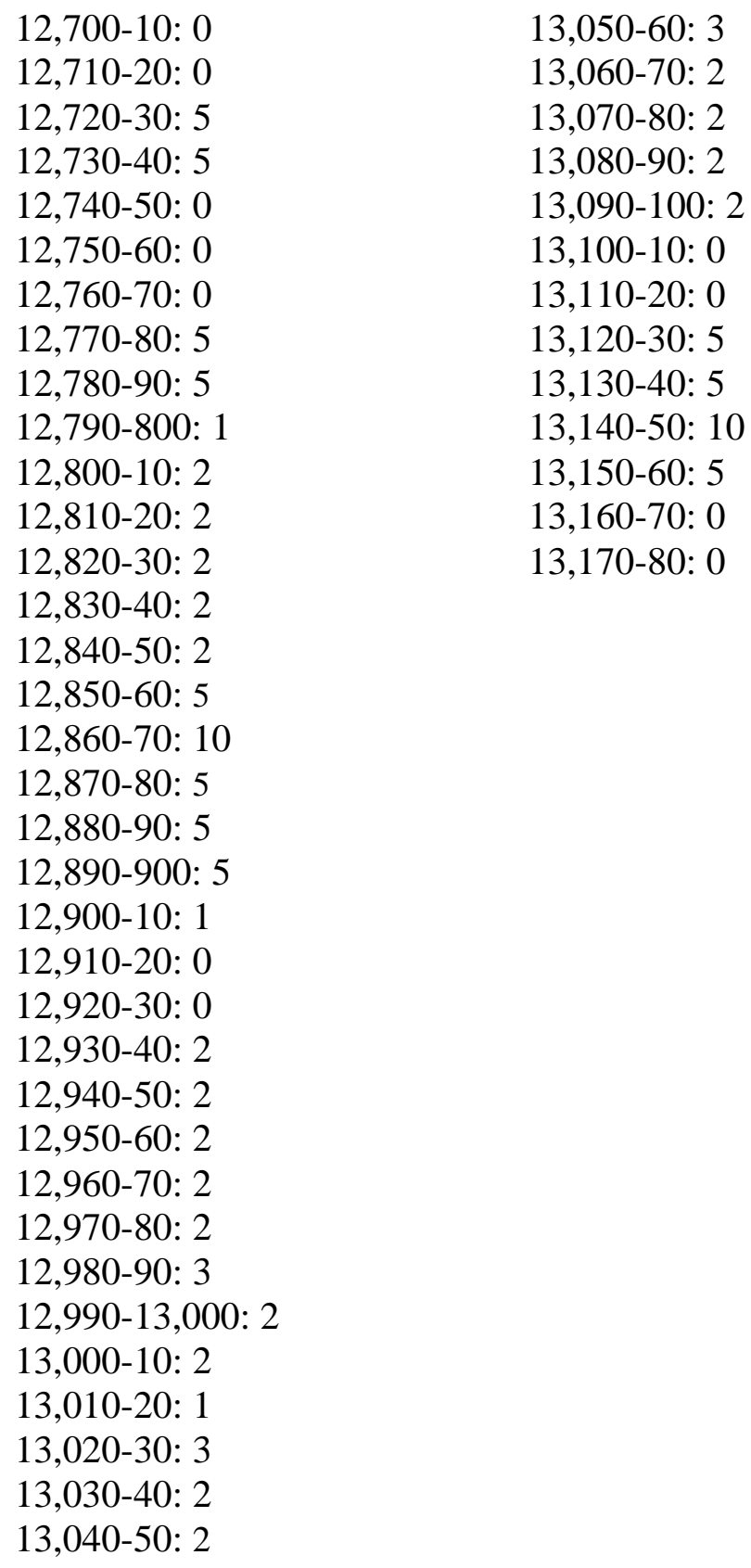




\section{APPENDIX C FRACTURE CUTTING COUNTS}

The methodology of fracture cutting counts is described in Section C. Cuttings containing both walls of a fracture count as one fracture; those containing only one wall count as half a fracture. Sample depth intervals are given in feet, followed by the fracture cutting count. A ì--1̂ following the depth interval indicates samples that are too fine, contaminated, missing, or not examined.

\section{EE-2A}

9,742-50: 7

9,750-60: 2

9,760-70: 0

9,770-80: 1

9,780-90: 1

9,790-800: 0

9,800-10: 0

9,810-20: 7.5

9,820-30: 0.5

9,830-40: 4.5

9,840-50: 10.5

9,850-60: 11

9,860-70: 0

9,870-80: 3

9,880-90: 9

9,890-9,900: 3

9,900-10: --

9,910-20:

9,920-30: 8.5

9,930-40:

9,940-50:

9,950-60:

9,960-70:

9,970-80:

9,980-90:

9,990-10,000: --

10,000-10: 14

10,010-20: --

10,020-30: --

10,030-40: 5

10,040-50:

10,050-60: --

10,060-70: --

10,070-80: --

10,080-90: --

10,090-100: 21

10,100-10: 40.5

10,110-20: 34

10,120-30: 39.5

10,130-40: --

10,140-50: --

\author{
10,150-60: 22 \\ 10,160-70: - \\ 10,170-80: -- \\ 10,180-90: -- \\ 10,190-200: -- \\ 10,200-10: 17 \\ 10,210-20: -- \\ 10,220-30: -- \\ 10,230-40: -- \\ 10,240-50: -- \\ 10,250-60: 16 \\ 10,260-70: - \\ 10,270-80: -- \\ 10,280-90: -- \\ 10,290-300: -- \\ 10,300-10: 17.5 \\ 10,310-20: 18 \\ 10,320-30: 11.5 \\ 10,330-40: 15.5 \\ 10,340-50: 9.5 \\ 10,350-60: 22.5 \\ 10,360-70: 46.5 \\ 10,370-80: 94.5 \\ 10,380-90: 3 \\ 10,390-400: 4.5 \\ 10,400-10: 11 \\ 10,410-20: 25 \\ 10,420-30:-- \\ 10,430-40: -- \\ 10,440-50: -- \\ 10,450-60: -- \\ 10,460-70: -- \\ 10,470-80: -- \\ 10,480-90: -- \\ 10,490-500: 59.5 \\ 10,500-10: -- \\ 10,510-20: -- \\ 10,520-30: 68 \\ 10,530-40: 75.5 \\ 10,540-50: -- \\ 10,550-60: 72.5
}

\author{
10,560-70: -- \\ 10,570-80: 92.5 \\ 10,580-90: -- \\ 10,590-600: -- \\ 10,600-10: 41 \\ 10,610-20: -- \\ 10,620-30: -- \\ 10,630-40: -- \\ 10,640-50:-- \\ 10,650-60: -- \\ 10,660-70: -- \\ 10,670-80: -- \\ 10,680-90: -- \\ 10,690-95: 37.5 \\ 10,695-700: 31 \\ 10,700-05: 41 \\ 10,715-20: 56 \\ 10,720-30: -- \\ 10,730-40: -- \\ 10,740-50:-- \\ 10,750-60: 55 \\ 10,760-70: -- \\ 10,770-80: -- \\ 10,780-90: -- \\ 10,790-800: -- \\ 10,800-10: 27.5 \\ 10,810-20: -- \\ 10,820-30: -- \\ 10,830-40: -- \\ 10,845-50: 75 \\ 10,850-60: -- \\ 10,860-70: -- \\ 10,870-80: -- \\ 10,880-90: -- \\ 10,890-900: -- \\ 10,900-10: 46.5 \\ 10,910-20: -- \\ 10,920-30: 26 \\ 10,930-40: 33 \\ 10,940-50: -- \\ 10,950-60: -- \\ 10,960-70: 12
}

12,000-05: 0.5

10,970-80: --

11,500-10: 5.5

C-1 


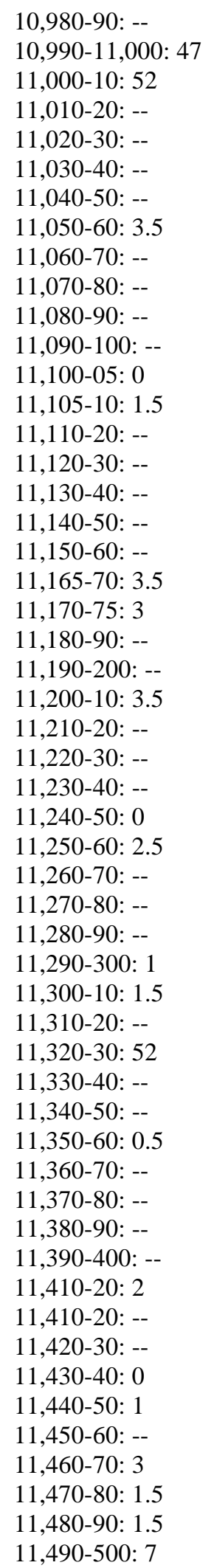

10,980-90: -11,000-10: 52

11,010-20: --

11,020-30:

11,040-50: --

11,050-60: 3.5

11,060-70: --

11,070-80: --

11,090-100: --

11,100-05: 0

11,105-10: 1.5

11,130-40: --

11,140-50: --

11,150-60: --

11,165-70: 3.5

11,190-200: --

11,200-10: 3.5

11,220-30: -.

11,230-40: --

11,240-50: 0

11,250-60: 2.5

11,270-80:

11,280-90: --

11,290-300: 1

11,300-10: 1.5

11,310-20: --

11,320-30: 52

11,330-40: --

$11,350-60: 0.5$

11,360-70: --

11,370-80: --

11,380-90: --

11,390-400: -

11,410-20: 2

11,410-20: --

11,420-30: --

11,430-40: 0

11,440-50: 1

11,450-60: -

11,470-80: 1.5

11,490-500: 7

\begin{tabular}{|c|c|}
\hline 11,510-20: -- & 12,010-20: -- \\
\hline 11,520-30: -- & 12,025-30: 3 \\
\hline 11,530-40: -- & $12,035-40: 5$ \\
\hline 11,540-50:-- & $12,040-45: 4$ \\
\hline 11,550-60: 1 & 12,045-50: 7 \\
\hline 11,560-70: -- & $12,050-55: 0.5$ \\
\hline 11,570-80: -- & 12,055-60: 0.5 \\
\hline 11,580-90: 2.5 & 12,060-70: -- \\
\hline 11,590-600: -- & 12,070-80: -- \\
\hline 11,600-10: -- & 12,080-90: -- \\
\hline 11,610-20: -- & 12,090-100: -- \\
\hline 11,620-30: -- & 12,100-10: 1 \\
\hline 11,635-40: 3 & 12,110-20: 0 \\
\hline 11,640-50: -- & 12,120-30: -- \\
\hline $11,650-55: 46.5$ & 12,130-40: 31 \\
\hline 11,655-60: 21 & 12,140-50: 5.5 \\
\hline $11,660-65: 3$ & 12,150-60: 3 \\
\hline 11,670-80: -- & 12,160-70: -- \\
\hline 11,680-90: -- & 12,170-80: -- \\
\hline 11,695-700: 2 & 12,180-90: -- \\
\hline $11,700-05: 6.5$ & 12,190-200: -- \\
\hline 11,710-20: -- & 12,200-10: 0 \\
\hline $11,720-25: 2.5$ & 12,210-20: -- \\
\hline $11,725-30: 1.5$ & 12,220-30: -- \\
\hline 11,730-35: 0 & 12,230-40: -- \\
\hline 11,740-45: 1 & 12,240-50: -- \\
\hline $11,750-55: 0$ & 12,250-60: 0 \\
\hline 11,760-65: 0 & 12,260-70: -- \\
\hline 11,770-75: 0 & 12,270-80: -- \\
\hline $11,780-85: 5.5$ & 12,280-90: -- \\
\hline 11,790-95: 9 & $12,290-300: 3.5$ \\
\hline 11,800-05: 10 & 12,300-10: 0 \\
\hline $1,810-15: 13.5$ & 12,310-20: 3 \\
\hline 11,820-25: 0 & $12,320-30: 2$ \\
\hline $11,830-35: 0.5$ & 12,330-40: -- \\
\hline 11,840-45: 0 & 12,340-50: -- \\
\hline 11,845-50: 0.5 & 12,350: 0.5 \\
\hline \multicolumn{2}{|l|}{ 11,850-60: -- } \\
\hline 11,860-65: 1 & EE-3A \\
\hline 11,870-80: -- & 9,595-600: 5.5 \\
\hline 11,880-90: -- & 9,600-10: -- \\
\hline 11,890-900: -- & $9,610-15: 1.5$ \\
\hline 11,900-05: 0 & $9,620-25: 2$ \\
\hline 11,910-20: -- & 9,630-40: -- \\
\hline 11,920-30: -- & 9,640-50: -- \\
\hline 11,935-40: 1 & 9,650-60: -- \\
\hline $11,940-45: 67.5$ & 9,660-70: -- \\
\hline 11,945-50: 37 & 9,670-80: -- \\
\hline $11,950-55: 7$ & 9,680-90: -- \\
\hline 11,960-70: -- & $9,690-95: 5.5$ \\
\hline 11,970-80:-- & $9,695-700: 2$ \\
\hline 11,980-90: -- & $9,700-05: 5.5$ \\
\hline 11,990-12,000: -- & $9,710-15: 5.5$ \\
\hline
\end{tabular}


9,720-25: 2

9,730-35: 2

9,740-45: 42.5

9,750-55: 12.5

9,760-65: 17

9,770-75: 6

9,780-85: 7.5

9,790-95: 5

9,800-05: 3

9,810-15: 14.5

9,820-25: 14

9,830-35: 11.5

9,840-45: 7.5

9,850-55: 6.5

9,860-65: 11

9,870-75: 6

9,875-80: 7

9,880-05: 7.5

9,890-05: 20.5

9,900-05: 22.5

9,910-15: 11

9,920-25: 13

9,930-35: 9

9,940-45:--

9,950-55: 4

9,960-65: 4.5

9,970-75: 3

9,980-85: 4.5

9,990-10,000: 2

10,000-05: 14.5

10,010-15: 13.5

10,020-25: 24

10,030-35: 16

$10,040-45: 4.5$

10,050-55: 6.5

10,060-65: 12

10,070-75: 4

10,080-85: 6

10,090-95: 3.5

10,100-10: --

10,110-15: 8

10,120-30: --

10,130-40: --

10,140-50: 12

10,150-60: 10

10,160-70: 8.5

10,170-80: 4

10,180-90: 15

10,190-200: 5

10,200-10: --

10,210-20: --

10,220-30: --

10,230-40: 11.5

10,240-50: 2.5

11,750-60: --

11,760-70: --

11,770-80: --
10,250-60: --

10,260-70: --

10,270-80: 2

10,280-90: 3

10,290-300: --

10,300-10: 15

10,310-20: 20

10,320-30: 4.5

10,330-40: 7

10,340-50: 17.5

10,350-60: 15

10,360-70: 5

10,370-80: 5

10,380-90: 7

10,390-400: 12

10,400-10: 6.5

10,410-20: 5

10,420-30: 7

10,430-40: 10.5

10,440-50: 21.5

10,450-60: 49

10,460-70: 49

10,470-80: 44

10,480-90: 20.5

10,490-500: 34.5

10,500-10: 45.5

10,510-20: 31.5

10,520-30: 14

10,530-40: --

10,540-50: 7

10,550-60: 8

10,560-70: 14.5

10,570-80: 16.5

10,580-90: 37.5

10,590-600: 11

10,600-10: 5.5

10,610-20: 11

10,620-30: 9.5

10,630-40: 8

10,640-50: 15

10,650-60: 7.5

10,660-70: 16

10,670-80: 13

10,680-90: 13.5

10,690-700: 11.5

10,700-10: 1

10,710-20: 4

10,720-30: 6

10,730-40: 5

10,740-50: 5.5

10,750-60: 9

10,760-70: 4.5

10,770-80: 4

10,780-90: 2.5

12,290-300: --

12,300-10: 6.5

12,310-20: 3.5
10,790-800: 1.5

10,800-10: 2

10,810-20: 8

10,820-30: 23

10,830-40: 12.5

10,840-50: 2

10,850-60: 2

10,860-70: 8

10,870-11,300: --

11,300-10: --

11,310-20: --

11,320-30: --

11,330-40: --

11,340-50: --

11,350-60: --

11,360-70: --

11,370-80: --

11,380-90: --

11,390-400: --

11,400-10: 3.5

11,410-20: --

11,420-30: --

11,430-40: --

11,440-50: --

11,450-60: 12.5

11,460-70: --

11,470-80: 0

11,480-90: 13.5

11,490-500: 1

11,500-10: --

11,510-20: --

11,520-30: --

11,530-40: --

11,540-50: --

11,550-60: --

11,560-70: 0

11,570-80: 10.5

11,580-90: 3.5

11,590-600: --

11,600-10: 5.5

11,610-20: --

11,620-30: --

11,630-40: --

11,640-50: --

11,650-60: 6

11,660-70: --

11,670-80: --

11,680-90: --

11,690-700: --

11,700-10: --

11,710-20: --

11,720-30: 10

11,730-40: 17

11,740-50: 8 
11,780-90: 6

11,790-800: 9.5

11,800-10: 6.5

11,810-20: 1

11,820-30: --

11,830-40: --

11,840-50:

11,850-60: 0.5

11,860-70: --

11,870-80: --

11,880-90: --

11,890-900: --

11,900-10: 2.5

11,910-20: --

11,920-30: --

11,930-40: --

11,940-50: 1

11,950-60: --

11,960-70: --

11,970-80: --

11,980-90: --

11,990-12,000: --

12,000-10: 0.5

12,010-20: --

12,020-30: --

12,030-40: --

12,040-50: --

12,050-60: 10

12,060-70: --

12,070-80: --

12,080-90: --

12,090-100: --

12,100-10: 0.5

12,110-20: --

12,120-30: --

12,130-40: 12

12,140-50: --

12,150-60: 1

12,160-70: 8.5

12,170-80: --

12,180-90: 0

12,190-200: --

12,200-10: --

12,210-20: 4

12,220-30: --

12,230-40: --

12,240-50: --

12,250-60: --

12,260-70: 14.5

12,270-80: --

12,280-90: --
12,320-30: -12,330-40: -12,340-50: -12,350-60: 2 12,360-: -- 
This report has been reproduced directly from the best available copy. It is available electronically on the Web (http://www.doe.gov/bridge).

Copies are available for sale to U.S. Department of Energy employees and contractors from:

Office of Scientific and Technical Information

P.O. Box 62

Oak Ridge, TN 37831

(865) 576-8401

Copies are available for sale to the public from: National Technical Information Service

U.S. Department of Commerce

5285 Port Royal Road

Springfield, VA 22161

(800) 553-6847 
- Los Alamos NATIONAL LABORATORY 